Myocarditis in

Forensic Medicine 



\section{Myocarditis in Forensic Medicine}

A Difficult Diagnosis That Requires a Multidisciplinary Approach

PhD Thesis by

Trine Skov Nielsen

Department of Health Science and Technology, Aalborg University, Denmark

and

Centre for Clinical Research, Vendsyssel Hospital

\section{River Publishers}


ISBN 978-87-93237-02-5 (paperback)

ISBN 978-87-93237-01-8 (e-book)

Published, sold and distributed by:

River Publishers

Niels Jernes Vej 10

9220 Aalborg $\varnothing$

Denmark

Tel.: +45369953197

www.riverpublishers.com

Copyright for this work belongs to the author, River Publishers have the sole right to distribute this work commercially.

All rights reserved (c) 2014 Trine Skov Nielsen.

No part of this work may be reproduced, stored in a retrieval system, or transmitted in any form or by any means, electronic, mechanical, photocopying, microfilming, recording or otherwise, without prior written permission from the Publisher. 


\section{Preface}

The work presented in this dissertation was performed in the laboratories of Centre for Clinical Research, Vendsyssel Hospital, Aalborg University, the Department of Forensic Medicine, Aarhus University and Statens Serum Institut, Copenhagen during my employment as a PhD student at Centre for Clinical Research, Vendsyssel Hospital, Aalborg University, Denmark.

Financial support was generously provided by the Beckett Foundation, The A.P Moeller Foundation for the Advancement of Medical Science, Kirsten Anthonius Mindelegat, Kong Christian den Tiendes Foundation, Department of Forensic Medicine, Aarhus University and Aalborg University.

The PhD thesis is based on the following scientific papers:

Paper I: "Quantitative diagnosis of lymphocytic myocarditis in forensic medicine"

Trine Skov Nielsen, Jens Randel Nyengaard, Jesper Møller, Jytte Banner, Lars Peter Nielsen, Ulrik Baandrup Forensic Science International 2014, vol 238, p. 9-15

Paper II: "The presence of enterovirus, adenovirus and parvovirus B19 in myocardial tissue samples from autopsies - an evaluation of their frequencies in deceased individuals with myocarditis and in noninflamed control hearts"

Trine Skov Nielsen, Jakob Hansen, Lars Peter Nielsen, Ulrik Baandrup, Jytte Banner

Forensic Science, Medicine, and Pathology 2014 Sep;10(3):344-50

Paper III: "Saffold Virus infection associated with human myocarditis"

Trine Skov Nielsen, Alex Yde Nielsen, Jytte Banner, Ulrik Baandrup, Lars Peter Nielsen

\section{Supervisors}

Ulrik Baandrup, MD, PhD, Professor, Principal Supervisor, Centre for Clinical Research, Vendsyssel Hospital, Aalborg University, Denmark

Jytte Banner, MD, PhD, Professor, Supervisor, Department of Forensic Medicine, Copenhagen University, Denmark

Lars Peter Nielsen, MD, Supervisor, Statens Serum Institut, Copenhagen, Denmark

\section{Evaluation Comittee}

Claus Bøgelund Andersen, MD, DMSc, Department of Pathology, Rigshospitalet, Copenhagen, Denmark Joaquín Lucena, MD, PhD, Institute of Legal Medicine, Seville, Spain Lars Hvilsted Rasmussen, MD, PhD, Chairman of the committee, Department of Clinical Medicine, Aalborg University Hospital 


$\begin{array}{ll}\text { Abbreviations } \\ \text { PVB19 } & \text { Human Parvovirus B19 } \\ \text { FFPE } & \text { Formalin Fixed Paraffin Embedded } \\ \text { H\&E } & \text { Hematoxylin and Eosin } \\ \text { PCR } & \text { Polymerase Chain Reaction } \\ \text { EMB } & \text { Endomyocardial biopsy } \\ \text { IgG } & \text { Immunoglobulin G } \\ \text { IgM } & \text { Immunoglobulin M } \\ \text { DCM } & \text { Dilated cardiomyopathy } \\ \text { SCD } & \text { Sudden cardiac death } \\ \mu \mathrm{m} & \text { Micro meter }\end{array}$




\section{Acknowledgements}

The work described in this thesis would not have been possible without the help and support from many people. First, I would like to thank my principal supervisor Professor Ulrik Baandrup for giving me the opportunity to work on this project, and for his excellent guidance and many inspiring discussions during the last three years. Your knowledge and genuine interest in this project has been an inspiration. I would also like to thank my supervisor Professor Jytte Banner for believing in me from the beginning and for her continuous help and never-ending enthusiasm. I look forward to continue our friendship and collaboration in the future. I also wish to thank my supervisor Lars Peter Nielsen for always having excited ideas and for his patient guidance through the world of microbiology. I am very grateful to all my supervisors for their inspiration, patience, encouragement, challenging demands, constructive criticism and help whenever needed.

I would like to express my thanks to Professor Jens R. Nyengaard for introducing me to the field of stereology and for taking the time to explain and discuss methods and results. I also wish to thank Professor Jesper Møller for statistical guidance.

I would like to thank everybody at the Centre for Clinical Research at Vendsyssel Hospital. In particular, I owe a great thank to Mette Skov Mikkelsen and Bente Wormstrup for cutting endless sections in the laboratory with an ongoing optimism. Also thanks to research secretary Kristina Hansel for being able to answer almost every possible question.

I wish to thank Jakob Hansen and Anette Funder at the Department of Forensic Medicine, Aarhus University for running countless tests in the laboratory. Especially thanks to Jakob Hansen for rewarding discussions of the virological results and drafting of the manuscripts.

I am very grateful to all of my colleagues at the Department of Forensic Medicine. Especially, I am grateful to the girls at the office; Maiken Larsen, Lisbeth Jensen, Seija Ylijoki-Sørensen, Trine Salomón, Mia Laursen and Camilla Nielsen. Thank you for your friendship, scientific input and many joyful hours. A special thank goes to Per Høgh Poulsen and Heidi Dusgaard for their ever-lasting friendship and support that goes beyond scientific work. Thank you also to Christian Bjerre Høyer for his friendship and inspiring discussions of almost everything.

The greatest thank goes to those who mean the most to me; my husband Casper and our wonderful children Regitze and William. You will always be my greatest success.

To the fond memory of my parents.

Trine Skov Nielsen, April 2014 


\section{Table of content}

Preface

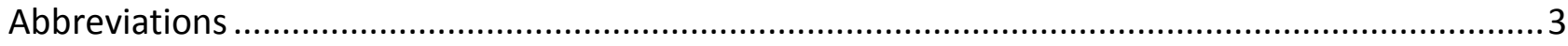

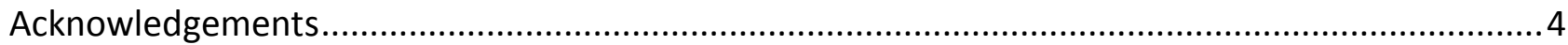

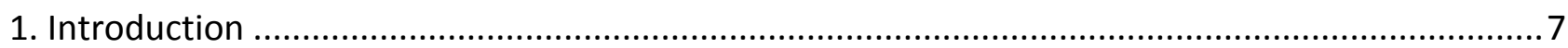

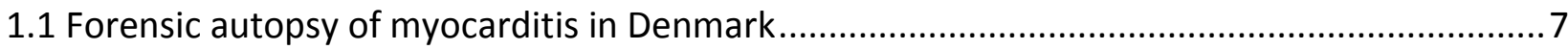

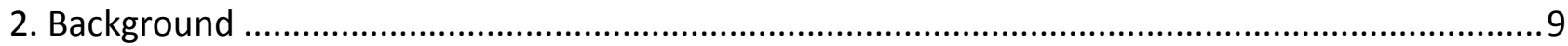

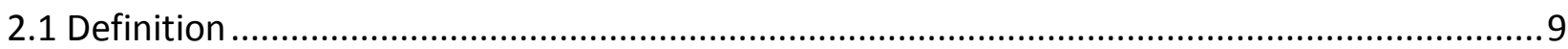

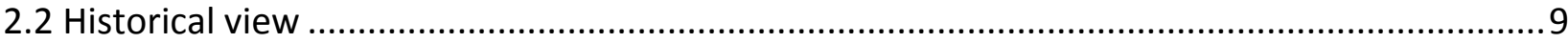

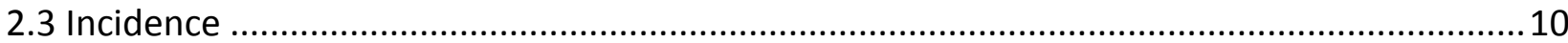

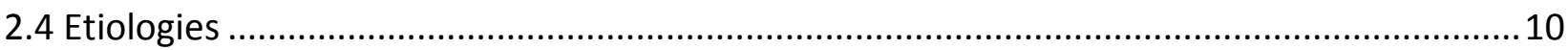

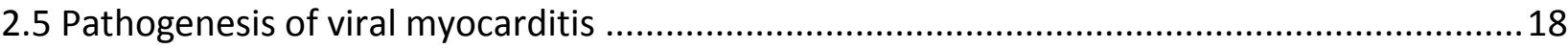

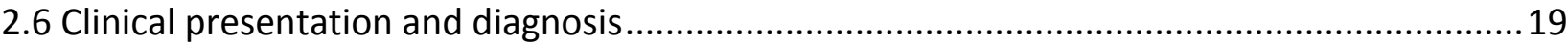

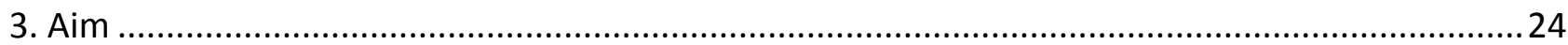

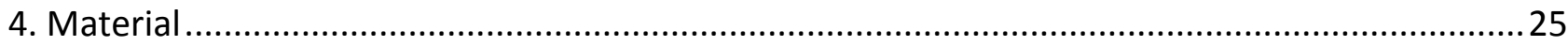

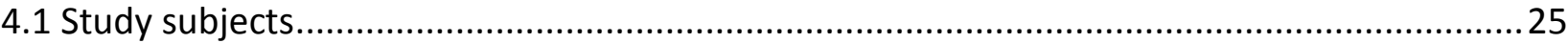

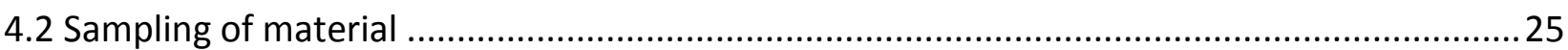

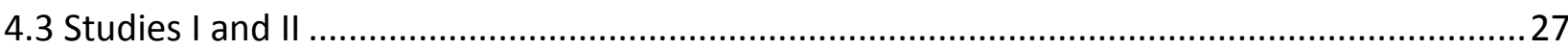

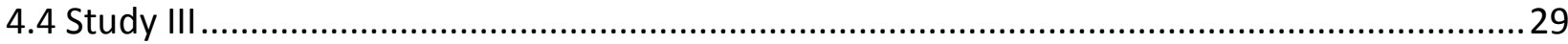

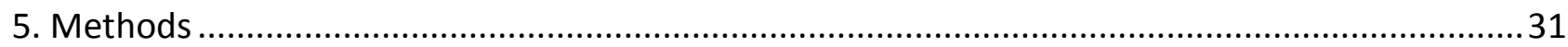

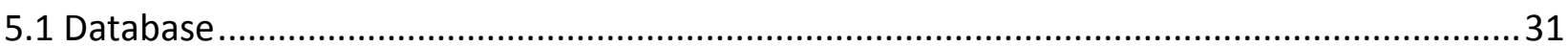

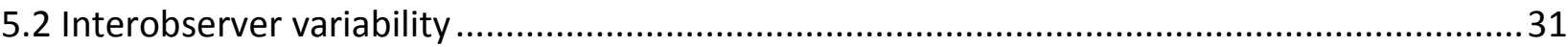

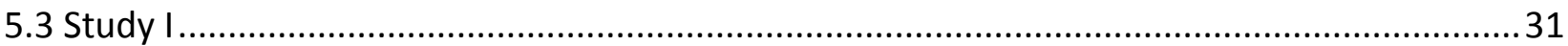

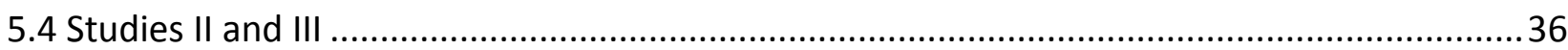

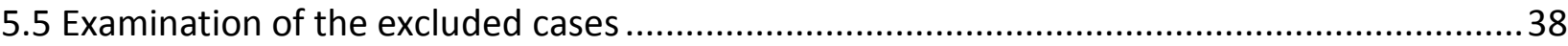

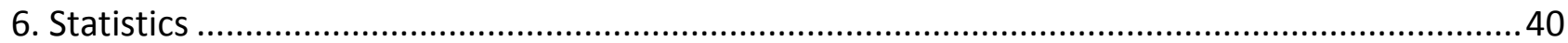

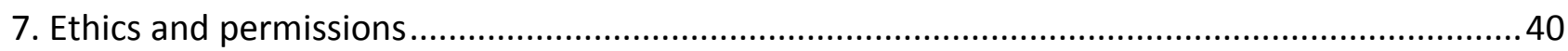

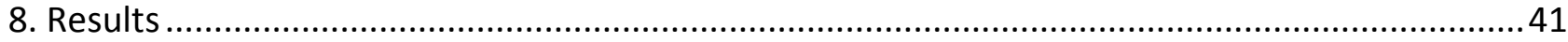

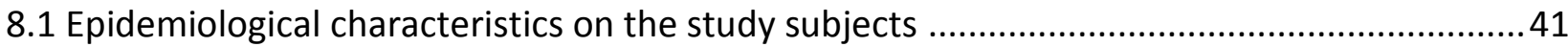


8.2 Characterization of inflammatory infiltrations . .43

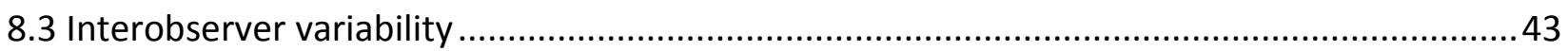

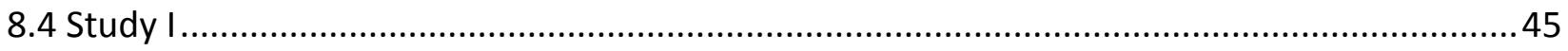

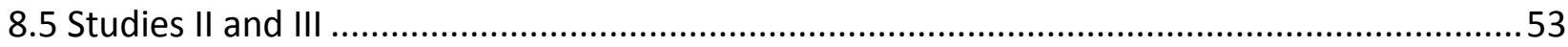

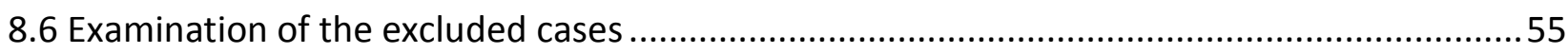

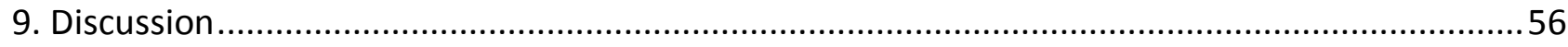

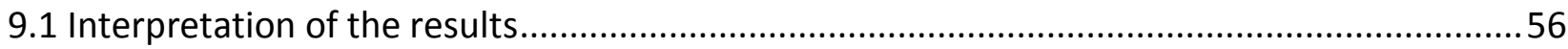

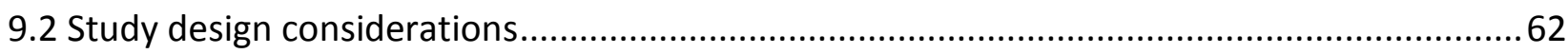

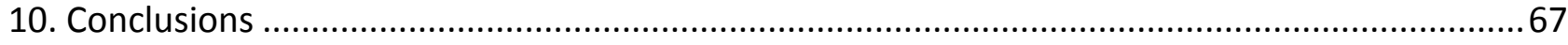

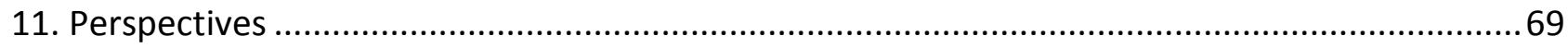

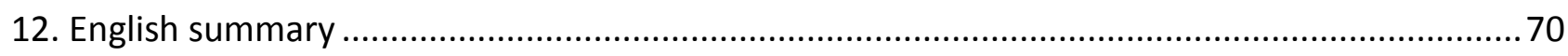

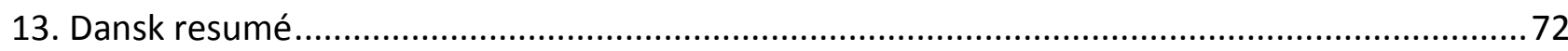

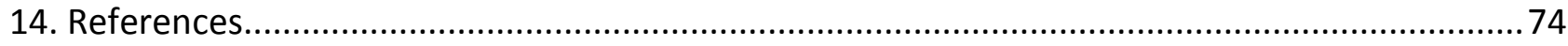

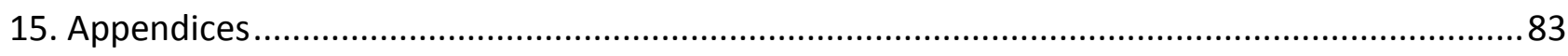

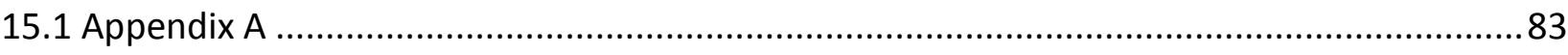

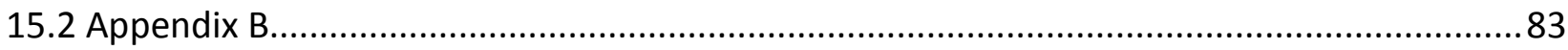




\section{Introduction}

\subsection{Forensic autopsy of myocarditis in Denmark}

In Denmark, suspicious deaths, deaths of unnatural manner and unexpected deaths must be reported to and investigated by the police. In most cases, a medico-legal external examination is performed by the police and a Medical Doctor of Health (Sundhedsloven, Kap 55) ${ }^{1}$. The final decision on whether to proceed to a forensic autopsy is made by the police and relies on the Danish legislation. According to Danish law a forensic autopsy shall be performed when death is caused by a criminal act or is suspected, when the manner of death cannot be established with a sufficient high degree of certainty during the medico-legal external examination or if the police for other reasons find that an autopsy is indicated (Sundhedsloven, Kapitel 56$)^{2}$. Furthermore, the Ministry of Health has decided that an autopsy shall be performed in drug-related deaths. In Denmark, a forensic autopsy is performed in $2.3 \%$ of all deaths, and $27 \%$ of all medico-legal external examinations are followed by a forensic autopsy ${ }^{3}$. In the majority (approximately $90 \%$ ) of forensic autopsy cases, the manner of death is natural. Whether a forensic autopsy is performed in myocarditis-related deaths will accordingly depend on the circumstances surrounding the death. In myocarditis cases a forensic autopsy will often be performed in certain cases of sudden unexpected death, un-witnessed death and some accident cases, while cases with a medical history of heart disease or other severe illness, will frequently be deselected, because both the cause and manner of death can be presumed.

A standard forensic autopsy in Denmark is preceded by an investigation of the death performed by the police, where information regarding circumstances of the death; lifestyle of the deceased, especially concerning the abuse of alcohol, medicine and illicit drugs; and medical history from relatives, general practitioner and hospital files is collected. The autopsy is often performed several days after death and includes an external and internal examination, with an evaluation of all organs. At the Department of Forensic Medicine, Aarhus University, where this project has been conducted, the heart of the deceased is handled according to a department-specific protocol concerning the routine examination of the heart ${ }^{\mathrm{A}}$. This protocol includes a detailed macroscopic

\footnotetext{
A In 2005, the specific department protocol was accredited according to general criteria; DS/EN is/IECL7020, 2005 (latest version)
} 
examination followed by a histological investigation. Routinely, the histological examination includes four myocardial specimens from the heart, which are sampled from four different locations. In selected cases, additional sampling from other locations, such as the conductive system, is performed. Toxicological screening and supplementary laboratory tests for diabetes, metabolic disorders and infections are performed when considered relevant for establishing the cause of death. Molecular autopsy according to the existing guidelines has not yet been integrated as a diagnostic procedure, but it has been performed in selected cases. Virological examinations have only been performed in a minority of cases in the past but are becoming increasingly more common.

Myocarditis constitutes a very important unsolved challenge in the practice of cardiovascular medicine. An early and accurate diagnosis is important because myocarditis is a significant cause of severe cardiac disease, including sudden cardiac death (SCD), especially in young individuals ${ }^{4-6}$. Furthermore, viral myocarditis is a potential precursor of dilated cardiomyopathy (DCM), which is a major cause of cardiac transplantation ${ }^{7}$. In the practice of forensic medicine, an accurate evaluation of myocardial inflammation is necessary to establish the correct cause of death. Many different criteria for the diagnosis of myocarditis have been proposed in recent years, and several guidelines have been recommended ${ }^{8-11}$. Histopathological evaluation is recommended as the gold standard for a definite myocarditis diagnosis, and a combination of histological, immunological and immunohistochemical examinations should be performed. However, the histological diagnosis of myocarditis remains challenging and is continuously debated. Recent improvements of molecular diagnostic tests have helped uncover viral etiologies, and routine polymerase chain reactions $(P C R)$ for the detection of viral genomes are now included in the recommendations to enhance the diagnostic contribution of the histological examination ${ }^{8-10}$. Despite this inclusion, only a few studies on the etiologic role of cardiotropic viruses in myocarditis-related deaths have been published $^{12-14}$.

The routine collection of myocardial tissue samples from all deceased individuals at the Department of Forensic Medicine, Aarhus University, has provided an opportunity to retrospectively study the histopathological and virological characteristics in myocarditis-related deaths and to evaluate the results by including a large control group of deceased individuals with normal hearts. 


\section{Background}

\subsection{Definition}

Myocarditis refers to an inflammatory disorder of the myocardium and is characterized by an infiltration of immunocompetent cells and the non-ischemic degeneration of cardiac myocytes. Myocarditis can be classified by causes (e.g., viral, bacterial, protozoal, toxic or hypersensitivity), histology (e.g., lymphocytic, neutrophilic, eosinophilic, granulomatous or giant cell) or clinical presentation (e.g., acute, fulminant or chronic). In 1995, myocarditis was defined by the World Health Organization/International Society and Federation of Cardiology Task Force as an inflammatory disease of the heart muscle diagnosed by established histological, immunological and immunohistochemical criteria ${ }^{9,15}$. The definition was made as part of several changes in the definition and classification of inflammatory heart diseases. The new classification also included inflammatory cardiomyopathy, defined as myocarditis in association with cardiac dysfunction. Despite its rather clear-cut definition, the diagnosis and classification of myocarditis continue to prompt considerable debate, particularly because the clinical and histological diagnoses of myocarditis show little correlation ${ }^{16-18}$.

\subsection{Historical view}

The term myocarditis, as we know it today, has slowly developed since the 19th century. In the beginning, heart diseases were classified as valvular or non-valvular; the non-valvular diseases were generally termed "carditis" and most likely included a variety of cardiac conditions. Myocarditis as an isolated condition of the myocardium was first described by Soberheim in $1837^{19}$. The diagnosis was primarily made on auscultation and at autopsy, but simple light microscopic examinations were also performed. The etiology was in generally obscure. In 1878, Ruhle first described myocarditis as part of an infectious disease, but it was considered to be part of a systemic infectious disease, not an isolated illness affecting the heart ${ }^{19}$. This specificity was not defined until the beginning of the 20 th century. Identification of a myocardial lesion by the presence of a specific cellular response led to the understanding of different possible origins. Thus, myocardial changes resulting from vascular conditions began to be separated from inflammatory myocarditis. However, specific attention to myocardial inflammation based on a viral or bacterial 
infection was not given until the middle of the 20th century. As different techniques emerged (e.g., culture techniques and electron microscopy), the first viruses were isolated from individuals diagnosed with myocarditis in 1945. The first viruses isolated were Influenza virus A and Coxsackie-virus B. With the first transvenous endomyocardial biopsy (EMB) completed in 1963, the material that was accessible for diagnosis increased significantly ${ }^{20}$. Since then, a broad spectrum of different microorganisms has been identified as causes of myocarditis, as have a variety of noninfectious causes.

\subsection{Incidence}

The frequency of myocarditis has been estimated in several studies, and the results are highly variable. Passarino et al. found an autopsy frequency of myocarditis of $0.5 \%$ in a series of consecutive autopsies, while Burlo et al. found it to be $5.1 \%$ in a similar study ${ }^{21,22}$. Diaz et al found myocarditis to constitute $1.3 \%$ of all natural deaths $s^{5}$. In an Australian study, myocarditis was found to cause $12 \%$ of SCD in young people, while a Spanish study only found it to cause $1 \%{ }^{4,23}$. Geographic differences may partially explain these dissimilarities, but discrepancies in the classification and interpretation of myocardial inflammation are likely of greater importance. The studies estimating the frequency of myocarditis are characterized by significant differences in applied methods, numbers of sections examined and numbers of investigators, which are all important factors affecting the myocarditis diagnosis. Myocarditis has been reported to be overdiagnosed ${ }^{24}$; however, it may instead be under-diagnosed, and the true frequency of myocarditis is unknown.

\subsection{Etiologies}

Myocarditis can result from a wide spectrum of causes, including infectious pathogens and toxic and hypersensitivity reactions (see Table 1). Viral infection is responsible for the majority of myocarditis cases in western countries. However, despite several well-described etiologies, the underlying cause of myocarditis often remains unidentified. 

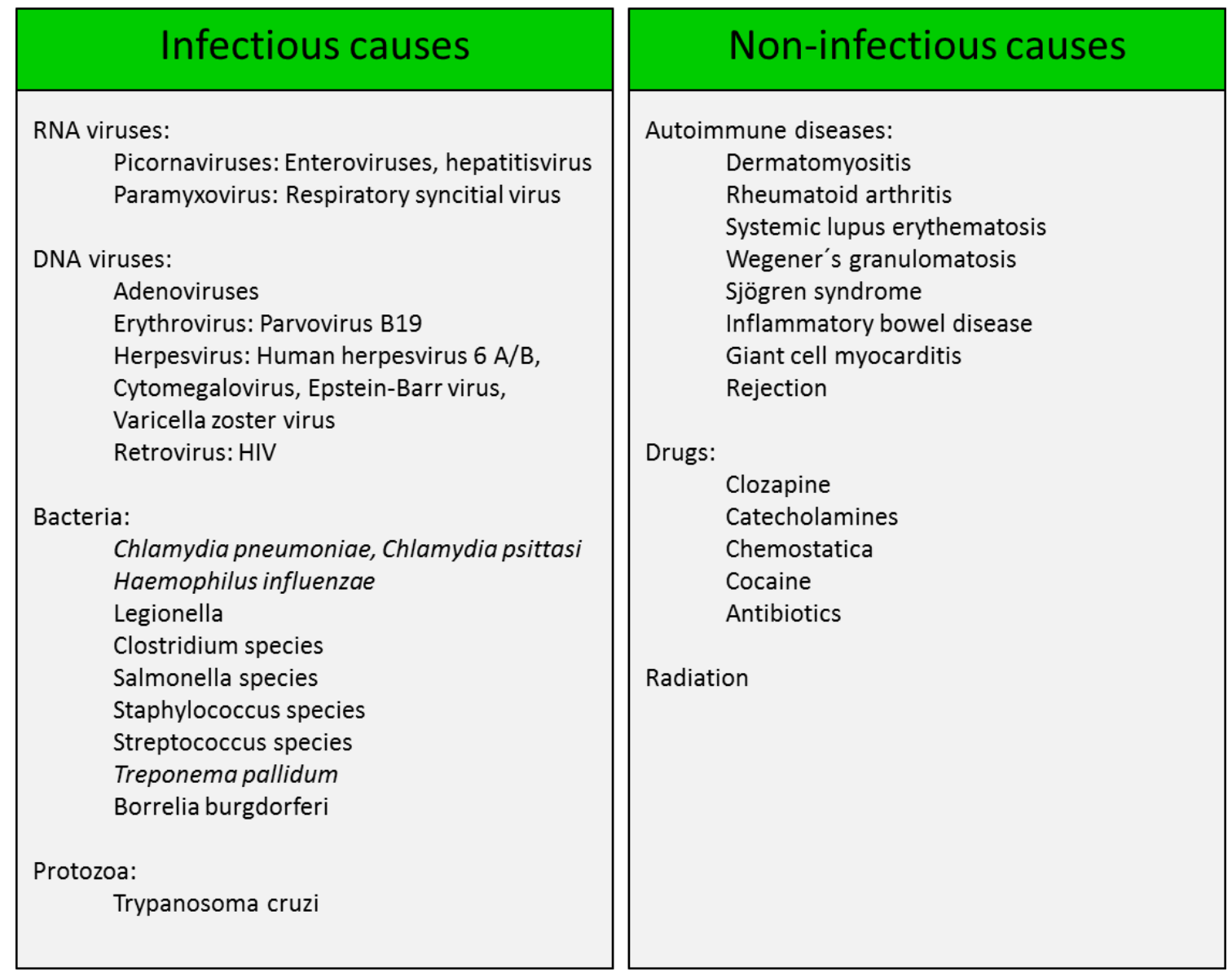

Table 1. Causes of myocarditis.

\section{Viral causes}

Several studies have examined the presence of viral genomes in the myocardium. Multiple viruses have been detected, but their frequencies are highly variable as shown in Table 2. Furthermore, the number and types of viruses examined are different from study to study. 


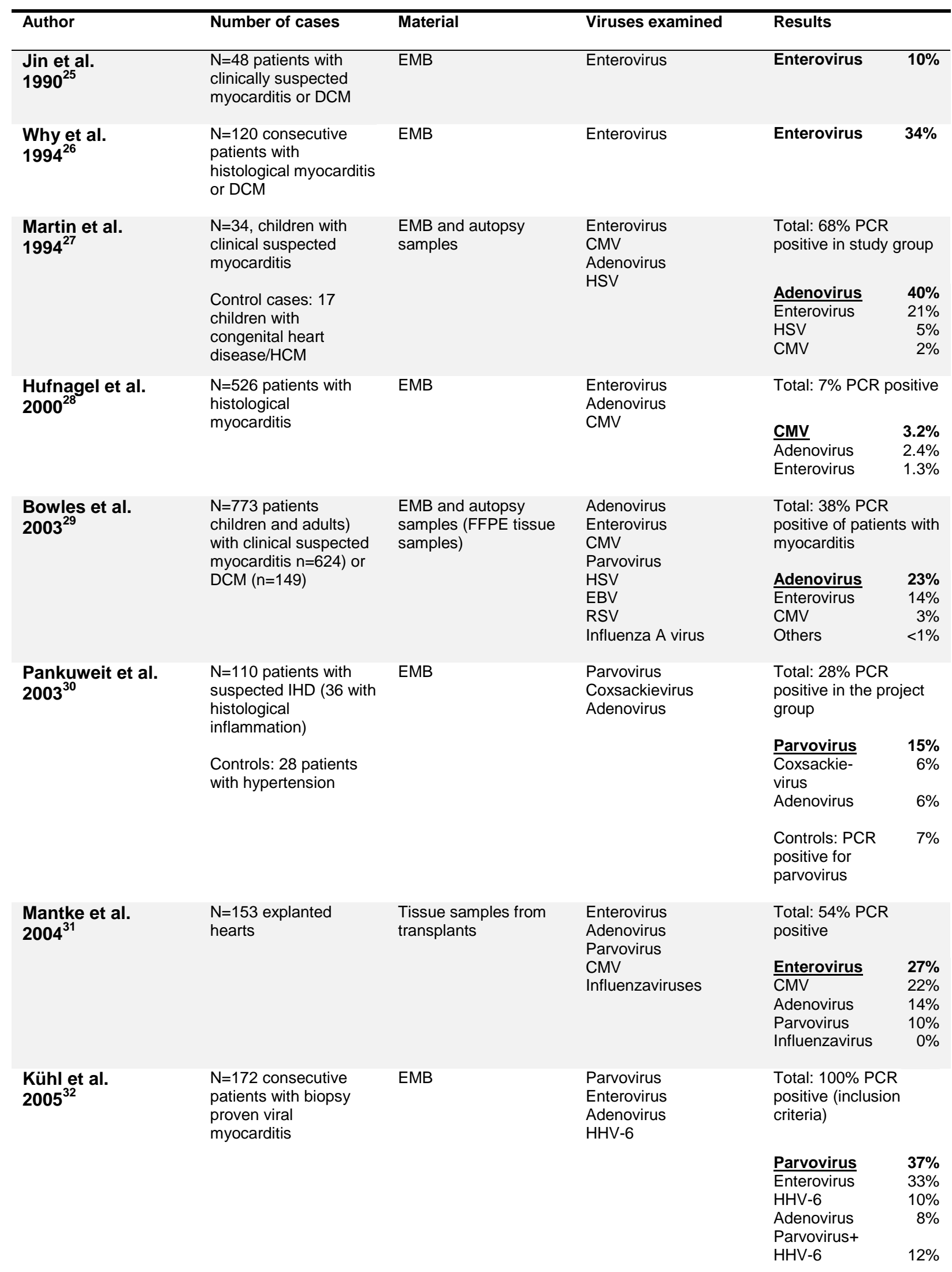




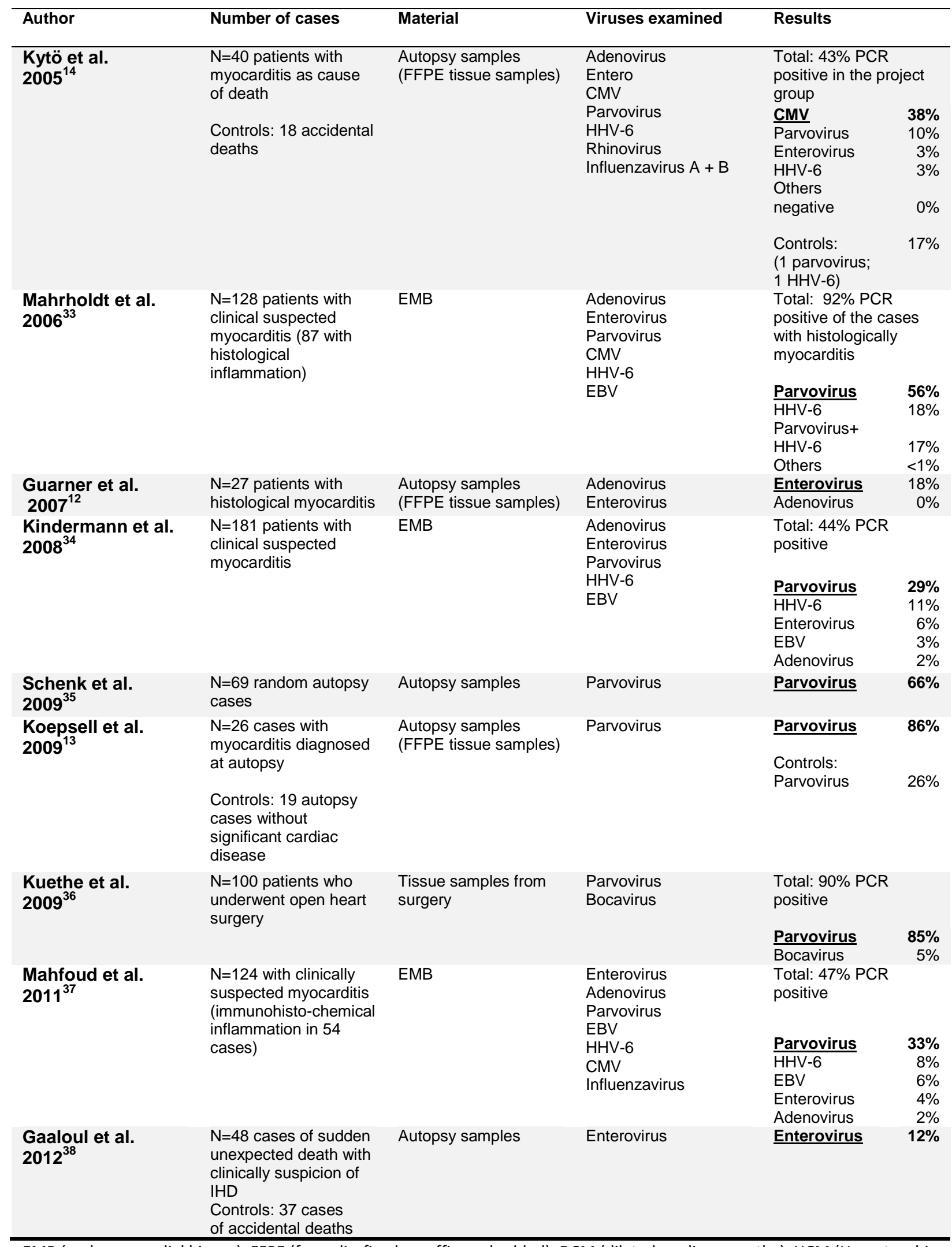

EMB (endomyocardial biopsy), FFPE (formalin-fixed paraffin-embedded), DCM (dilated cardiomyopathy), HCM (Hypertrophic cardiomyopathy), IHC (inflammatory heart disease), HSV (Herpes simplex virus), CMV (cytomegalovirus), HHV-6 (Human herpes virus 6), EBV (Epstein-Barr virus). Bold type: the most prevalent virus in each study.

Table 2. Different published results of virological analyses on myocardial tissue samples. 
Enterovirus, adenovirus and parvovirus B19 (PVB19) have been reported as the most frequently detected causes of myocarditis, but cytomegalovirus, human herpes virus-6, influenza viruses $A$ and B, Epstein-Barr virus and others have also been identified. As seen in Table 2, the overall presence of viral DNA/RNA in the myocardium from all the examined viruses ranged between $7 \%$ 92\%. Most of the previously reported studies examining the presence of viruses in the myocardium are based on living patients, while only a few studies on autopsy material exist. These studies only include a small number of cases and studies with a large control group of individuals with non-inflamed hearts are missing.

\section{Enterovirus, adenovirus and PVB19: The viral shift}

Enterovirus was one of the first viruses to be associated to myocarditis. It was the most commonly detected virus in some of the first studies examining the presence of viral genomes in the myocardium with frequencies reported from $1.3 \%$ to $34 \%{ }^{26,28}$. Adenoviruses were increasingly reported as a cause of myocarditis during the 1990s with frequencies from $2 \%$ to $40 \%$ between 1994 and $2011^{27,37}$. However, analyses of adenovirus in myocarditis/suspected myocarditis cases have also been negative in several studies ${ }^{12,14,33}$. Enteroviruses and adenoviruses most commonly affect infants and young adults, although persons of all ages can be infected ${ }^{29,}$ 39-41. In a study from the Unites States, myocarditis caused by enteroviruses was overrepresented among persons 15 years of age and older ${ }^{39}$. Both enteroviruses and adenoviruses are considered important causes of viral myocarditis, but their frequencies are reported to be decreasing. PVB19 was introduced as a possible cause of myocarditis in the 1990s. In contrast to enterovirus and adenovirus, PVB19 is detected in myocarditis case with increasing frequencies from $<1 \%$ to $86 \%{ }^{13}, 29$. PVB19 has been described as the most prevalent etiology to viral myocarditis today. This change in the most common viral etiologies of myocarditis from enterovirus to adenovirus and PVB19 over the last decades has been termed "the viral shift". Detailed information on enterovirus, adenovirus and PVB19 is given in Table 3. 


\begin{tabular}{|l|l|}
\hline Enterovirus & \\
\hline Family & Picornaviridae; $>200$ serotypes have been identified \\
Type & Non-enveloped, single-stranded RNA virus \\
\hline Clinical manifestation & Worldwide \\
\hline $\begin{array}{l}\text { Infections with enteroviruses are most often asymptomatic but may result in a } \\
\text { wide variety of symptoms ranging from mild respiratory illness; hand, foot and } \\
\text { mouth disease; conjunctivitis; generalized disease; aseptic meningitis; acute } \\
\text { flaccid paralysis; encephalitis and myocarditis. }\end{array}$ \\
\hline
\end{tabular}

\begin{tabular}{|l|l|}
\hline Adenovirus & Adenoviridae; $>50$ serotypes have been identified \\
\hline Family & Non-enveloped, double-stranded DNA virus \\
\hline Distribution & Worldwide \\
\hline Clinical manifestation & $\begin{array}{l}\text { Infections with enteroviruses mainly causes respiratory tract syndromes and } \\
\text { pneumonia, while infections of the gastrointestinal and urogenital systems and } \\
\text { the heart is less common. }\end{array}$ \\
\hline
\end{tabular}

\begin{tabular}{|l|l|}
\hline Parvovirus B19 & Parvoviridae \\
\hline Family & Non-enveloped, single-stranded DNA virus \\
\hline Type & Worldwide \\
Clinical manifestation & $\begin{array}{l}\text { Infections with parvovirus B19 is often asymptomatic, but in children it may } \\
\text { cause erythema infectiosum and in adults long-lasting arthritis. Most people } \\
\text { become infected with PVB19 during the first two decades of life. }\end{array}$ \\
\hline
\end{tabular}

Table 3. Characteristics of enterovirus, adenovirus and parvovirus B19.

With regard to affection of the heart, PVB19 has been associated with myocarditis as well as dilated cardiomyopathy, but its etiologic role remains controversial due to its ability to cause persistent infection. PVB19 was suggested to cause myocarditis based on the detection of PVB19 genomes in myocardial biopsies with inflammation ${ }^{13}$ 14, 29, 33, 34 . However, PVB19 has also been detected in autopsy samples where no myocarditis was present ${ }^{13,35}$, in cardiac transplant donors ${ }^{31}$ and in patients undergoing myocardial biopsy on suspicion of conditions not associated to myocardial inflammation ${ }^{36,42}$, suggesting that PVB19 is a bystander with no or limited association to myocardial inflammation. This suspicion is supported by the fact that PVB19 also has been found in bone marrow, synovial membranes and the skin of healthy adults ${ }^{43-45}$. These divergent findings make the PCR results ambiguous and the interpretation difficult.

Serological analyses of PVB19-specific immunoglobulin IgM and IgG can be used in addition to PCR analysis to differentiate between acute and persistent PVB19 infection. Infection with PVB19 induces a viremic phase, followed by the production of PVB19-specific antibodies. IgM antibodies appear 9 - 12 days after infection and are the first detectable immune reaction, indicating an acute PVB19 infection. The response is temporary and declines over the following weeks and IgM antibodies are usually undetectable after $8-12$ weeks. IgG antibodies are usually present two 
weeks following infection and persist lifelong ${ }^{46,47}$. In some individuals, especially immunocompromised subjects, long-lasting viremia may be present with or without the normal sequence in antibody subclasses. Most people become infected during their first two decades, and more than $70 \%$ of adults have PVB19-specific IgG antibodies ${ }^{48}$. The typical antibody response in PVB19 infection is shown in Figure 1. Because of the temporal overlap of the $\lg$ and $\lg$ antibodies, it is common to detect both antibodies at the same time; however, for a limited time period, IgM may be the only detectable antibody and indicates an early acute infection.

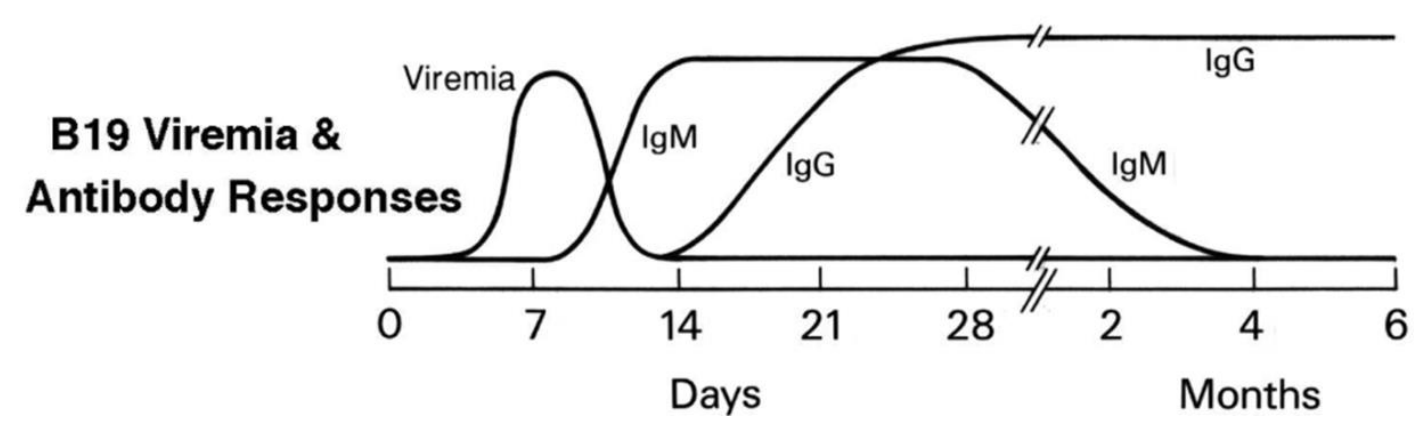

Figure 1. Antibody response in parvovirus B19 infection. Modified from Heegaard et al. ${ }^{47}$

The diagnostic value of PVB19-specific serology in cases with suspected myocarditis has previously been reported, with conflicting results ${ }^{32,36}, 37$. These studies primarily examined whether the presence of virus-specific IgM and IgG could predict an infection with the same virus in the myocardium and thereby reduce the need for EMB, which would be advantageous in a clinical setting. The use of PVB19-specific serology as a supplementary test to aid the interpretation of a positive PVB19 PCR in the myocardium is seldom reported ${ }^{49}$, and in most of the previously reported studies, the association of PVB19 with myocarditis relies solely upon detection of PVB19 genomes in the myocardium by PCR.

\section{$\underline{\text { Saffold virus }}$}

In virus-negative cases, the cause of myocarditis often remains unidentified, which can generate several hypotheses. Some of these cases may be explained by an infection with viruses other than those that are routinely examined. Novel viruses are continuously discovered and described, and 
based on their ability to cause diseases such as myocarditis in animals their pathogenicity in humans has been speculated. The saffold virus is one of these viruses whose association with human myocarditis needs to be described.

Saffold virus was first described by Jones et al in 2007, when the virus was isolated from a fecal sample from an 8-month-old child ${ }^{50}$. The genetic sequence of the virus indicated that it belonged to the genus Cardioviruses within the family Picornaviridae. Like the other Picornaviridae, saffold virus is a RNA virus. Cardioviruses infect animals, where it can cause asymptomatic intestinal infections. Extraintestinal spread can cause serious invasive infections, including myocarditis, diabetes, encephalomyelitis and a multiple sclerosis-like disease ${ }^{51-54}$. Since its discovery, saffold virus has been isolated from respiratory secretion and stool samples from children with respiratory and gastrointestinal symptoms in Canada, Brazil, Germany and California ${ }^{55-57}$. SAFV has also been detected in stool samples from South Asian children with paralysis and from children without neurologic symptoms ${ }^{52}$. These finding indicate that saffold virus is distributed worldwide and can be found in respiratory and fecal specimens from children with or without symptoms. In two studies from Denmark and Germany, SAFV has been detected in the myocardium, cerebrospinal fluid and blood, suggesting a more invasive role in human infections ${ }^{58,59}$. However, it was not possible to associate the detection of the virus to histopathological alterations in the affected organs in these studies.

\section{Non-viral causes}

Numerous bacterial agents can cause myocarditis, but bacterial-induced myocarditis is less frequently reported than viral-induced myocarditis. Especially in the United States, Borrelia burgdorferi is a relative common cause of myocarditis ${ }^{60}$. Myocarditis caused by a bacterial infection is mostly observed in immunosuppressed individuals, where myocarditis can manifest as part of a severe systemic infective condition. Protozoans, fungi and parasites can also cause myocarditis, and in developing countries Trypanosoma Cruzi (Chagas' disease) is the most common etiology of myocarditis and often induces chronic heart failure in affected individuals ${ }^{61}$. Non-infectious causes of myocarditis include toxins and hypersensitivity reactions. Among the many different kinds of drugs associated with myocarditis, clozapine, anthracyclines and cocaine are the most well documented ${ }^{62-66}$. Antibiotics and antidepressant have also been linked to 
myocarditis; however, their role is far from fully elucidated ${ }^{62,67}$. Numerous autoimmune systemic diseases, like systemic lupus erythematosus, and sarcoidosis, can induce myocarditis through immunological mechanisms ${ }^{68,69}$.

\subsection{Pathogenesis of viral myocarditis}

Most attention has focused on understanding viral-induced myocarditis. The pathophysiology in humans is only poorly understood, and most current knowledge has been obtained from animal studies. Generally, the course of viral myocarditis is described in three phases ${ }^{10,}$ 70-74. Phase 1 (acute phase) is characterized by the entrance of the virus into cardiac cells by virus-specific receptors, followed by directly virus-induced myocardial injury, with apoptosis and necrosis. The cardiotropic viruses have different target cells; adenoviruses and enteroviruses are often detected within the cardiomyocytes as virus-specific receptors are located on the myocyte cell surface while PVB19 mainly infects endothelial cells ${ }^{70,75,76}$. After entrance, the activation of the host's immune system leads to an invasion of mostly macrophages and T lymphocytes, which cause further cardiac injury. Phase 2 (subacute phase) is primarily characterized by immune reactions, which typically lead to viral clearance and down-regulation of the immune system, with no further adverse effects. However, in a few cases, the immune reactions will continue due to viral persistence and/or autoimmune reactions because of antigen mimicry or a genetic predisposition toward the development of cardiac autoantibodies directed against myocardial structures, often referred to as post-viral autoimmunity. These cases will progress into phase 3 (chronic phase), which is characterized by myocardial remodeling, cardiac dysfunction and DCM. The time course of the different phases is shown in Figure 2 and is derived from murine models. As illustrated, viral genomes, cellular infiltrations and antibodies are present at different times during the three phases. 


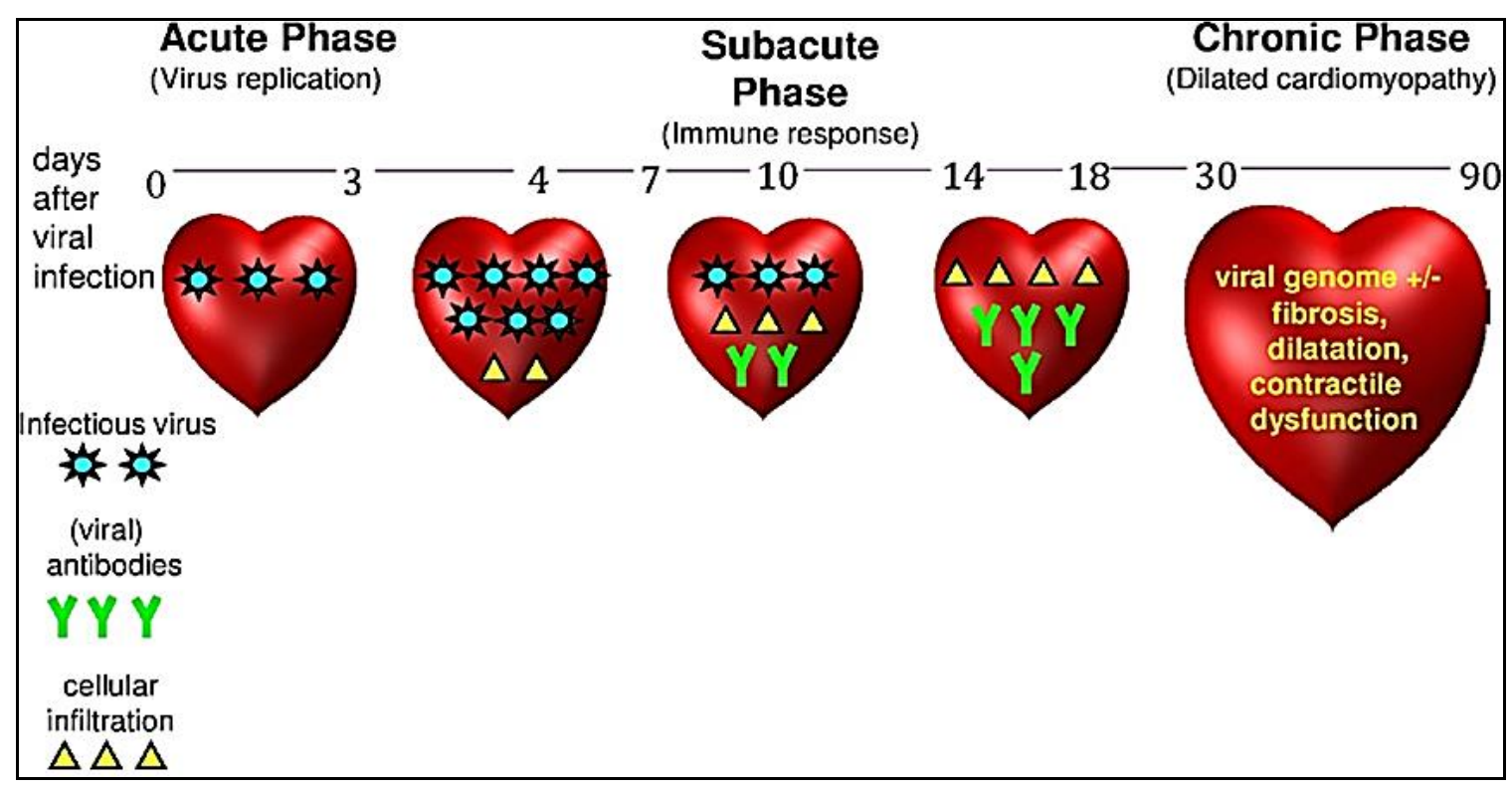

Figure 2. Time course of viral myocarditis. Figure from Kindermann et al ${ }^{10}$ (Reprinted with permission).

Myocarditis-related death may occur in all three phases, but the mechanisms leading to death have not been fully elucidated. In the late phases end-stage heart failure may lead to death/cardiac transplantation, while death in the early phases is thought to be caused by arrythmia $^{77}$. Hence, death during all phases may be subjected to forensic examination.

\subsection{Clinical presentation and diagnosis}

The clinical presentation of myocarditis is highly variable, ranging from subclinical disease to the manifestation of heart failure or sudden cardiac death as the first symptom ${ }^{7}$. $78-80$. A viral prodromal phase of fever or respiratory or gastrointestinal symptoms is not uncommon ${ }^{81}$, while the onset of myocarditis is frequently accompanied by dyspnea, chest pain and arrhythmic events $^{28,34}$. The clinical diversity at presentation, which is mainly dominated by nonspecific symptoms and findings, makes the diagnosis of myocarditis difficult.

Different approaches for the diagnosis of myocarditis can be utilized. Several less invasive diagnostic tests, such as serum biomarkers, electrocardiography and echocardiography are available, but the results are often non-specific and do not enable myocarditis to be differentiated from other cardiac diseases, especially ischemic conditions ${ }^{82-86}$. Cardiovascular magnetic 
resonance $(C M R)$ is a new emerging diagnostic tool for myocarditis. It can detect myocardial edema and myocyte necrosis with sensitivities reported between $44-90 \%{ }^{87,88}$. However, CMR cannot characterize or quantify the inflammatory infiltrations and thereby provide an assumption of the underlying etiology. Despite the low sensitivity and specificity of these tests, in combination, these results may add important supplementary information to histological evaluation, which remains the gold standard for a definite diagnosis of myocarditis. For autopsy cases, however, the results of premortem diagnostic tests are unfortunately not always available.

\section{Histopathological examination}

The extension and distribution of the inflammatory changes in myocarditis are highly variable and include small solitary inflammatory foci, multifocal aggregates and diffuse widespread inflammation. The histological pattern can be categorized by the most predominant cell type and classified as lymphocytic, neutrophilic, eosinophilic, granulomatous and giant cell. The predominant cell type often reflects the underlying etiology, but a significant overlap exists among categories. Lymphocytic myocarditis is reported as the most common type ${ }^{24,89}$. However, small foci of inflammatory cells have also been demonstrated as common incidental findings at autopsy in cases of non-cardiac death ${ }^{67,90}$.

In a clinical setting, the histological diagnosis of myocarditis is performed with EMB, which is generally sampled from the right ventricle. However, EMB is not routinely performed when myocarditis is suspected due to the risks associated to the procedure. The EMBs are small (1-4 $\mathrm{mm}^{3}$ ) and include the endocardium and the myocardium. Number and size of the biopsies influence the sensitivity of EMB for diagnosing myocarditis. Chow et al and Hauck et al demonstrated that from a single EMB, myocarditis could be diagnosed in $25 \%$ of cases according to the Dallas criteria. With $>5$ biopsies, myocarditis could be diagnosed in approximately twothirds of subjects. To obtain a sensitivity of $80 \%, 17$ biopsies should be examined ${ }^{91,} 92$. Furthermore, serial sectioning of the biopsies increases the sensitivity of EMB when evaluating myocarditis $^{93}$. These findings indicate a high risk of sampling error, and the number of EMB that is sufficient to provide a satisfactory diagnostic yield is widely debated ${ }^{94,95}$.

In an autopsy setting, the un-limited accessibility to the myocardium at postmortem is a diagnostic advantage. Macroscopically only few changes, if any, are seen in acute myocarditis. In severe 
prolonged cases, the heart can be enlarged, with a speckled myocardium at the cut surface. However, this appearance is not pathognomonic for myocarditis. For a histological examination, transmural tissue specimens from different locations of the heart can be obtained. The number and locations of tissue specimens that should be obtained to diagnose myocarditis at autopsy are not reported. However, in cases of myocarditis presenting as SCD autopsy guidelines, including histological examination are available ${ }^{96}$.

\section{Histopathological diagnostic criteria}

In 1987 the Dallas Classification System was developed to provide the first uniform criteria for the diagnosis of myocarditis on EMB. The criteria divided myocarditis into "Myocarditis" or "Borderline Myocarditis" based on the presence of inflammatory infiltrates with/or without myocyte necrosis ${ }^{97}$. However, this classification had several important limitations, in that it was susceptible to variation in pathological interpretation and sampling error and did not consider the underlying cause of the pathological findings ${ }^{81,98,99}$. The Dallas criteria were based on the presence of inflammatory infiltrates and did not consider diffuse inflammation. Furthermore, Kindermann et al. showed that myocarditis according to the Dallas criteria is a poor predictor of outcome with regard to cardiac death and transplantation ${ }^{34}$. Thus, the Dallas criteria are no longer considered adequate for the diagnosis of myocarditis. Both interobserver variability and sensitivity have been improved following the introduction of immunohistochemistry, which allows a more detailed identification, characterization and quantification of inflammatory cells ${ }^{100,}{ }^{101}$. Consequently, to increase the diagnostic yield of EMB, several other diagnostic approaches have been taken including different scoring methods to discriminate myocarditis from insignificant inflammatory findings ${ }^{102,103}$ as well as diagnostic criteria based on a semi-quantitative assessment of inflammatory cells in the myocardium.

\section{Quantitative criteria}

Quantitative diagnostic criteria for EMB were introduced for the first time in 1982 by Edwards et al. Based on their results, they suggested that a mean of more than 5.0 lymphocytes per highpower field (x 400) was indicative of active lymphocytic myocarditis ${ }^{104}$. This cut-off value was later modified by Kuhl et al. in 1994, who considered a mean number greater than 6.0 lymphocytes per $\mathrm{mm}^{2}$ myocardium indicative for inflammation ${ }^{105}$. Both studies established their criteria by 
estimating and comparing the presence of lymphocytes in EMB from myocarditis/DCM patients with control subjects consisting of patients with other known heart diseases (atherosclerosis, valvular diseases and hypertrophic cardiomyopathy). Along with the introduction of the term inflammatory cardiomyopathy in 1995, the request for uniform diagnostic criteria increased. As a consequence, Maisch et al in 2000 suggested an immunohistochemical criterion of a cut-off value of $>14$ lymphocytes per $\mathrm{mm}^{2}$ myocardium, including up to 4 macrophages, as a reliable cell count for inflammation on EMB because this value was 2 standard deviations above the mean number of inflammatory cells in EMB from 50 hypertensive control patients. However, a lymphocytic focus ( $\geq$ 3 lymphocytes) can be diagnosed as myocarditis due to the nature of the infiltrate even when 14 lymphocytes and macrophages per $\mathrm{mm}^{2}$ are not reached ${ }^{106}$. The criteria by Maisch et al. are the most recent suggestions and are often referred to as the state-of-the art evaluation for EMB. Because neither the Dallas criteria nor the above-mentioned quantitative criteria were intended for performing postmortem diagnostics on autopsy samples, Feeley et al. quantitatively estimated the lymphocytes in a series of consecutive autopsies and confirmed the diagnostic criteria suggested by Maisch et al. ${ }^{107}$. Although autopsy procedures enable a more thorough investigation of the heart compared with EMB, only a few quantitative studies of both the inflamed and noninflamed myocardium from deceased are available ${ }^{49,107,108 .}$

One major important requirement for establishing quantitative criteria for the diagnosis of myocarditis is knowing the number of inflammatory cells in the healthy myocardium, which has only been investigated in a few studies. Linder et al. estimated the presence of lymphocytes in a small cohort $(n=10)$ of autopsy cases, where deceased individuals with known heart diseases (except atherosclerosis) were excluded ${ }^{109}$. The result was a mean lymphocyte profile count of 3.6 per $\mathrm{mm}^{2}$ myocardium. In most other studies, patients with other heart diseases served as control subjects, but because myocardial inflammation is associated with a variety of cardiac conditions, these control subjects may not represent the healthy myocardium.

In the previously reported studies on quantitative diagnostic criteria for myocarditis, different methodological approaches for the estimation of lymphocytes and macrophages were used ${ }^{67,104-}$ 108, 110, 111 . Generally, the methods are based on standard pathological examination, where the areas for investigation (counting areas) consist of high power fields arbitrarily chosen by the investigator, which is highly investigator dependent ${ }^{112}$. Detailed descriptions of the counting rules 
employed (e.g., selection of areas for histological investigation and identification and separation of positive cell profiles) including photo documentation are commonly absent, which also concerns the latest criteria suggested by Maisch et al. Furthermore, an assessment of the reproducibility of the data has not been included for any of the proposed criteria. 


\section{Aim}

The overall aim of the present study was to evaluate histological and virological findings in myocarditis-related deaths.

Study I To semi-quantitatively estimate the presence of lymphocytes and macrophages in the inflamed and non-inflamed myocardium using a 2-dimensional stereological cell profile counting method.

To compare the presence of lymphocytes and macrophages in the inflamed and noninflamed myocardium to suggest and evaluate quantitative diagnostic criteria for lymphocytic myocarditis in forensic medicine.

Study II To examine the presence of enterovirus, adenovirus and parvovirus B19 in inflamed and non-inflamed myocardial tissue samples to evaluate their frequencies and significance as causes of myocarditis in forensic medicine.

Study III To examine if saffold virus plays an etiologic role in myocarditis in forensic medicine. 


\section{Material}

\subsection{Study subjects}

\section{Project group}

All postmortem cases diagnosed with myocarditis were identified in the electronic database at the Institute of Forensic Medicine, Aarhus University, Denmark. A total of 150 cases were identified from 1992 - 2010. Positive cases were included, regardless of the cause of death.

\section{Control group}

The control group consisted of 100 suicide cases selected from the electronic database at the Institute of Forensic Medicine, Aarhus University, Denmark from 1992 - 2010. Cases with proven clinical or pathological heart diseases (myocarditis, atherosclerosis AHA IV-VIII, valvular diseases and cardiomyopathies) or severe traumatic cardiac injury following suicide were not included.

\subsection{Sampling of material}

From all cases in this study (project group and control group) four transmural myocardial specimens from each heart were included, as shown in Figure 3. These samples were obtained from the anterior wall of the left ventricle, the posterior wall of the left ventricle, the interventricular septum and the right ventricle. These four samples were routinely obtained at autopsy during the whole study period according to the department-specific protocol for routine histologic examination of the heart. The specimens were initially fixed in $4 \%$ buffered formalin for 48 hours and subsequently embedded in paraffin. 

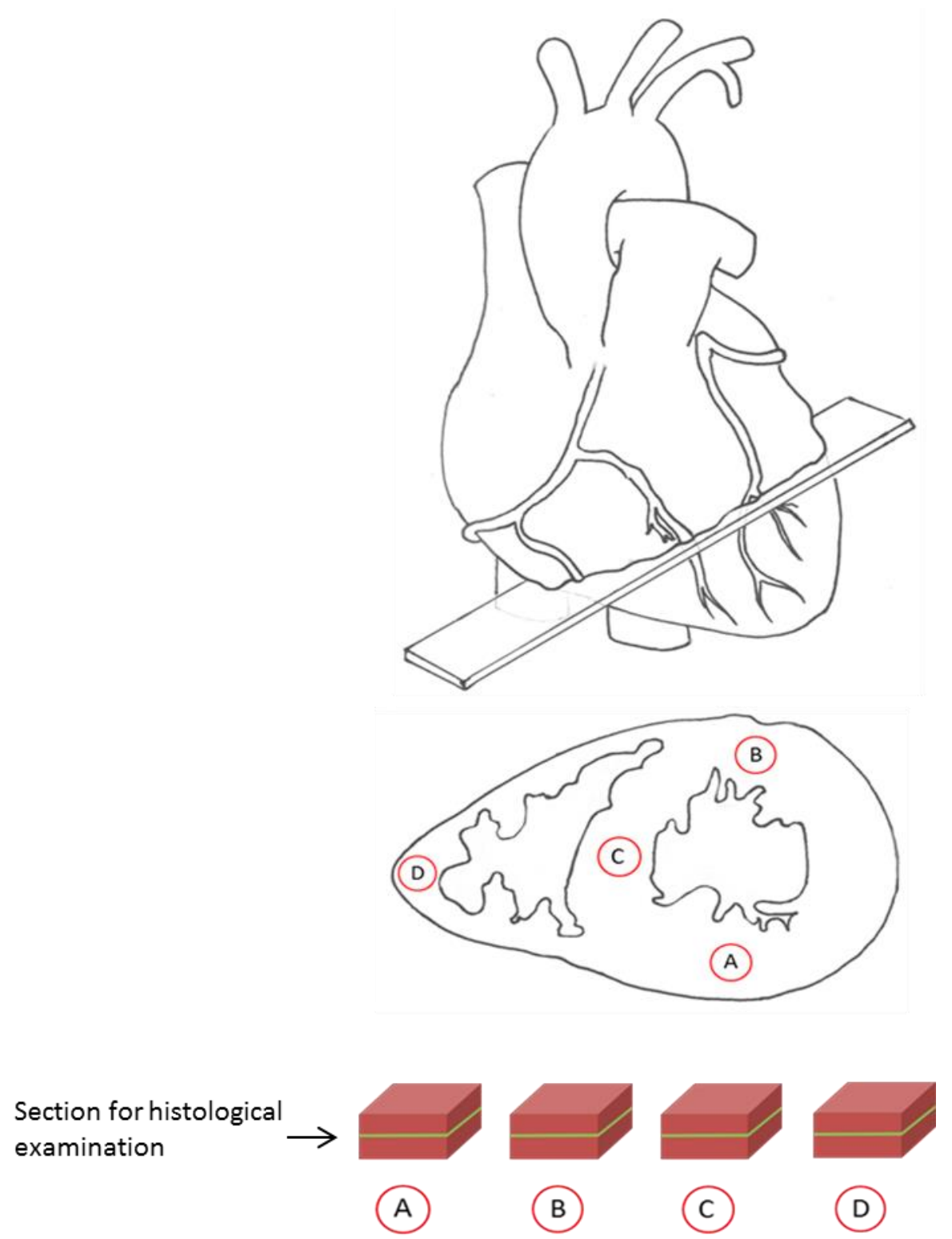

Figure 3. Sampling of transmural myocardial tissue specimens from autopsies.

A: sample from the anterior wall of the left ventricle

$B$ : sample from the posterior wall of the left ventricle

$C$ : sample from the interventricular septum

$D$ : sample from the right ventricle

In approximately $20 \%$ of the project cases, additional tissue specimens from the circumference and/or the conductive system were available, but we decided not to include these specimens in this study. 
Epidemiological data regarding histories of the deceased and autopsy findings were provided from autopsy files, police reports and, in some cases, hospital records.

\subsection{Studies I and II}

\section{Re-evaluation of the diagnosis}

The inclusion criterion for project cases was a myocarditis diagnosis made in relation to autopsy; thus, the diagnosis was made by different pathologists over the 19-year study period. Because the diagnosis is characterized by a high interobserver variation, we re-evaluated all cases to attain consistency of the material. Because not all the original H\&E-sections from the autopsy were available (sections prior to 1999 had been discarded) we cut new $3 \mu \mathrm{m}$ tissue sections from all formalin-fixed paraffin-embedded (FFPE) tissue blocks. Unfortunately, a few tissue blocks were missing for unknown reasons; therefore it was not possible to cut new sections from all 4 locations in all individuals. Consequently, a variable number of sections from each heart were available for examination ( $1-4$; mean: 3.5$)$. The new sections were stained with $H \& E$, after which the sections were re-evaluated according to the Dallas criteria and classified as "Myocarditis", "Borderline Myocarditis" or "No Myocarditis" based on the presence of inflammatory infiltrates with or without myocyte necrosis. For this study, an infiltrate was defined as a cluster of $\geq 10$ inflammatory cells. Myocyte necrosis was defined by a lack of distinct cell borders, pyknotic nuclei, loss of nuclei and cytoplasmatic vacuolization. Furthermore, the inflammatory changes were characterized by the most predominant cell type, i.e., lymphocytes, neutrophilic or eosinophilic granulocytes. A single investigator performed all re-evaluations.

Only cases with myocarditis or borderline myocarditis were included in the project group, while only cases without myocarditis or borderline myocarditis were included in the control group. The results of the re-evaluation are shown in Figure. 4 


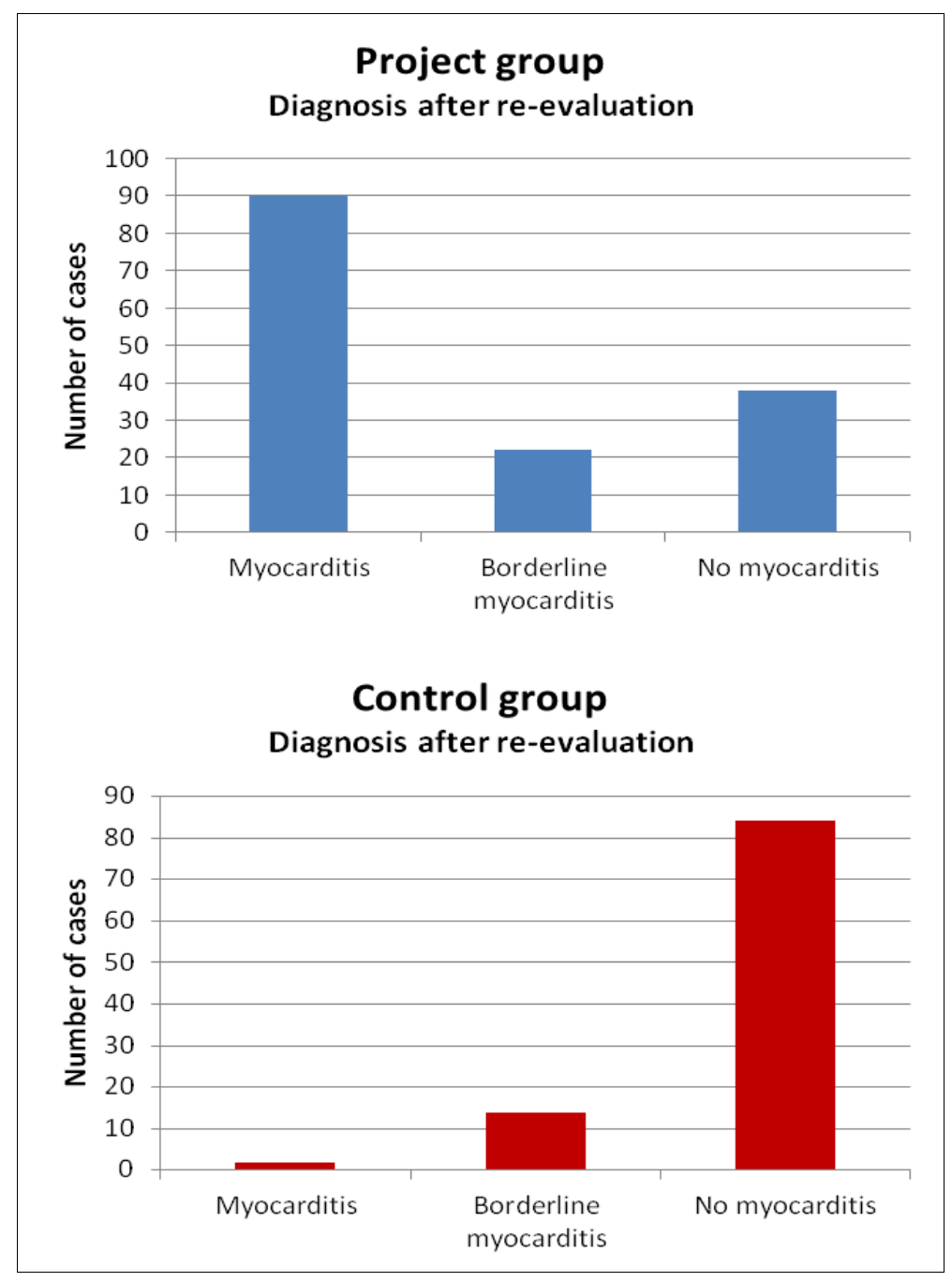

Figure 4. Classification of diagnoses in project and control groups after re-evaluation of H\&E sections according to the Dallas criteria.

As seen in Figure 4, the re-evaluation changed the autopsy diagnosis in some cases. In 38 of 150 cases in the project group, it was not possible to demonstrate inflammation by the re-evaluation. Consequently, these cases were excluded. In 16 of 100 cases in the control group, a diagnosis of either myocarditis $(n=2)$ or borderline myocarditis $(n=14)$ was established after the re-evaluation, and these cases were also excluded from the project.

The final study populations for studies I and II were as follows: project group, $n=112$ (78 men and 34 women; median age 35.8 years; age range 3 weeks to 77 years) and control group, $n=84$ (51 
men and 33 women; median age 36.9 years; age range 10 to 71 years). The age distribution is shown in Figure 5.

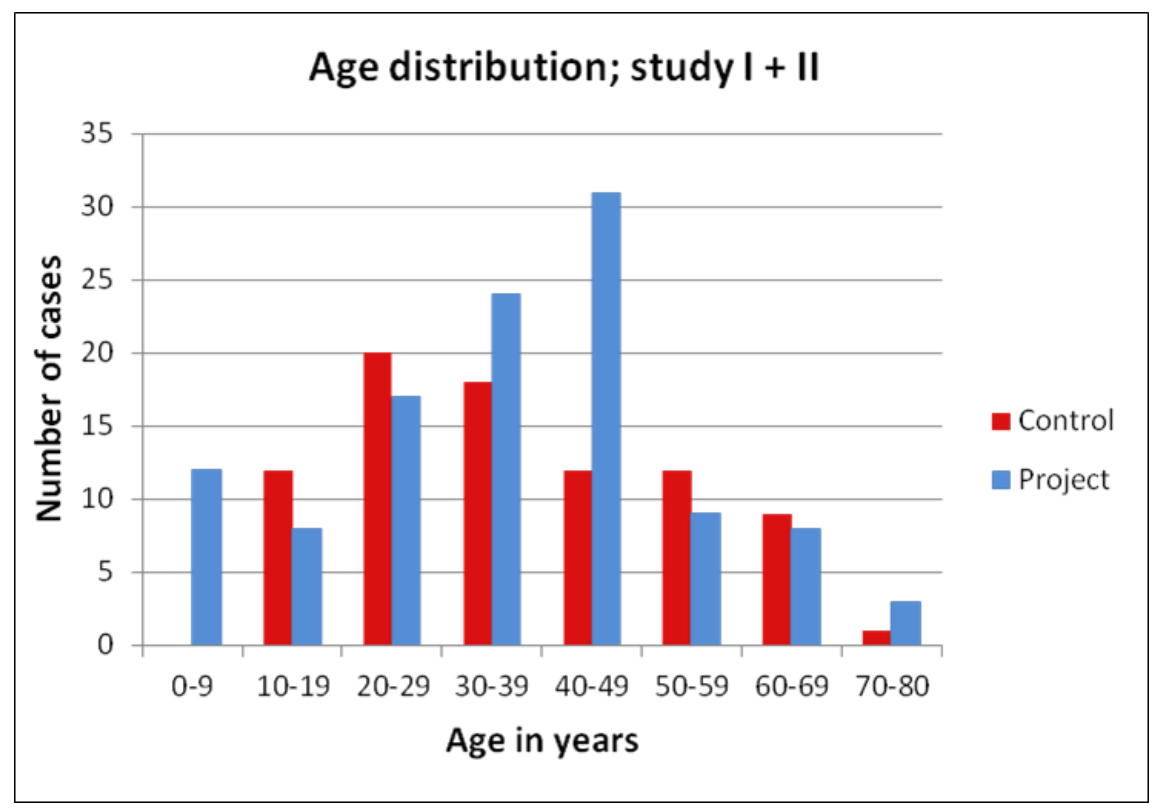

Figure 5. Age distribution of project and control cases in studies I and II.

\subsection{Study III}

The material for study III consisted of all 150 cases identified in the electronic database diagnosed with myocarditis at autopsy. A re-evaluation of the diagnosis was not performed for study III.

The study population for study III included 106 men and 44 women with a median age 34.7 years, and an age range of 3 weeks to 77 years. A control group for study III was not included. The age distribution is shown in Figure 6. 


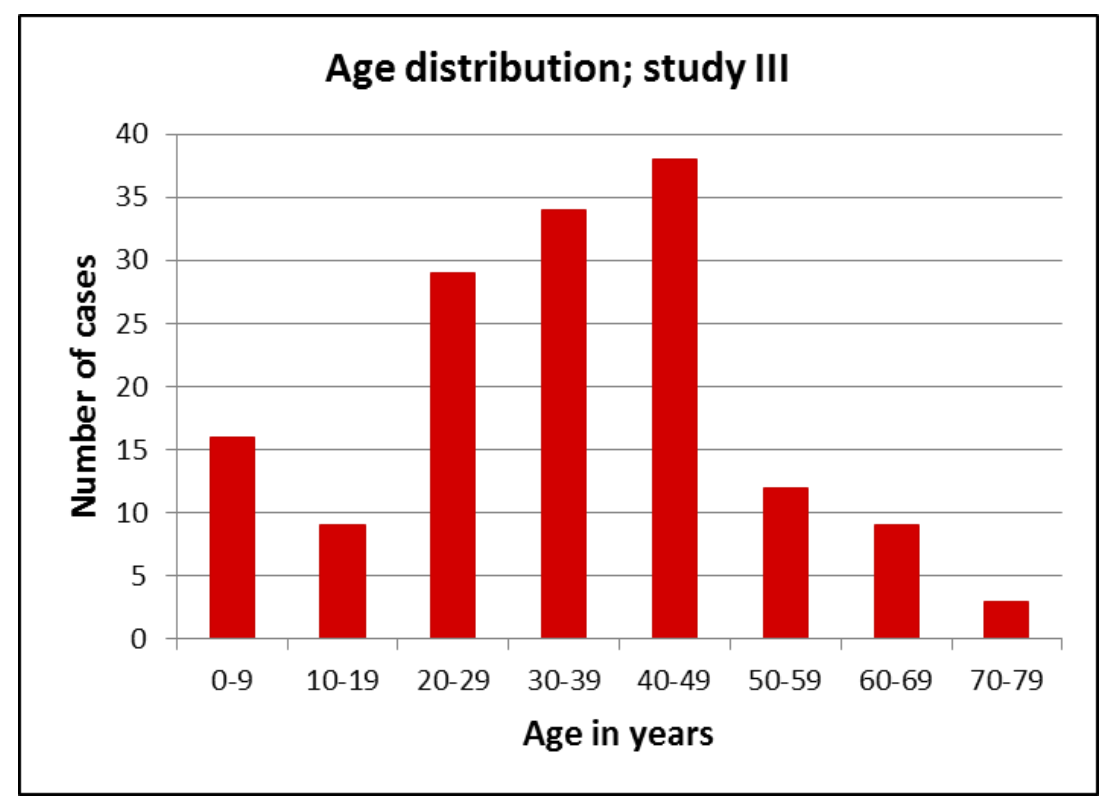

Figure 6. Age distribution of project cases in study III.

An overview of the study material for all three studies is presented in Figure 7.

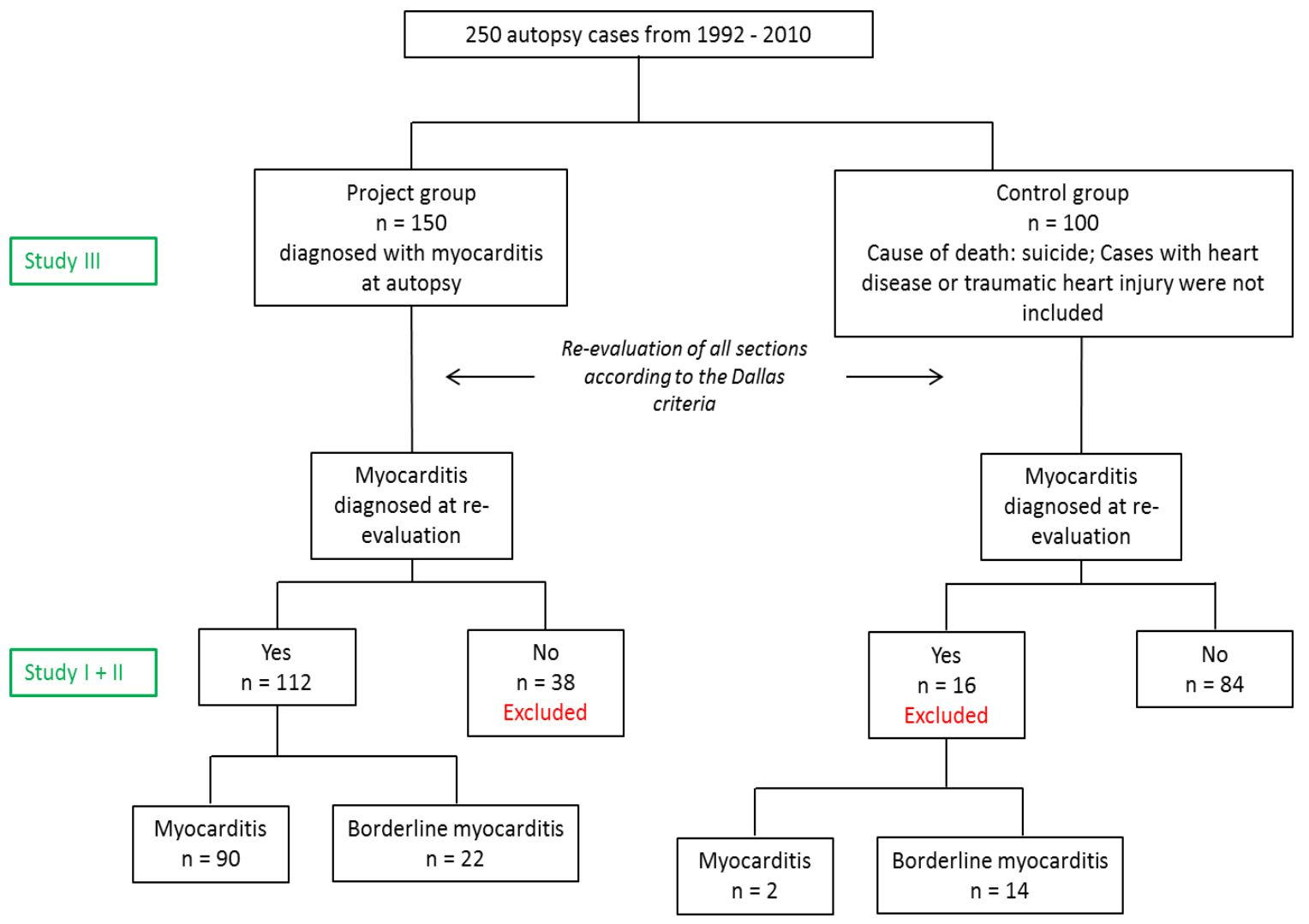

Figure 7. Overview of the study material. 


\section{Methods}

\subsection{Database}

For all three studies, a database was established using EpiData version 3.1 software package. For all cases, autopsy files, police reports and hospital records were reviewed, and the relevant epidemiological data regarding the deceased individuals' medical history, circumstances of death and autopsy findings were entered into the database along with the results of the stereological quantification and virological examinations.

\subsection{Interobserver variability}

The re-evaluation of the myocarditis diagnosis served as an important step in the definition of the final study population. Interobserver variability was assessed made with the primary aim of validating the investigators skills in identifying inflammatory changes in the myocardium on H\&E stained sections according to certain criteria. Interobserver variability was evaluated on 100 (10\%) randomly selected sections. The sections were examined by 2 observers, the primary investigator and a senior cardiovascular pathologist, for the presence of inflammatory infiltration(s) defined by the presence of a cluster of $\geq 10$ inflammatory cells.

\subsection{Study I}

\section{Immunohistochemical staining}

Histopathological examinations were performed of $3 \mu \mathrm{m}$ tissue sections cut from FFPE myocardial tissue blocks. For the diagnosis of lymphocytic myocarditis, sections were stained for Tlymphocytes with CD3 (Novocastra PS1) and macrophages with CD 68 (DAKO PG-M1) using monoclonal mouse anti-human antibodies. Staining was performed according to manufacturer's protocol; for a detailed description see appendix A.

All sections were blinded for group (project vs. control) and clinical information before examination. 


\section{Evaluation of immunohistochemical staining}

The sections were analyzed using a stereological cell profile counting method and systematic sampling of fields of view. Stereology covers different methods to obtain quantitative un-biased information of a three-dimensional material by measurements made in two-dimensional planes ${ }^{113 \text {, }}$ ${ }^{114}$. The methods are based on geometry and statistics. In this study, the fractionator principle for estimating the cell profile number was used. The fractionator principle states that an unbiased estimate of what one is interested in is given by

$\widehat{X}=\frac{X}{f} \quad 113,115$

$X$ represents the quantity of interest (number of cell profiles); $X$ with the caret is the estimate of $X$; the lowercase $x$ is the value counted from the sample; and $f$ is the fraction sampled. For an unbiased result, the examined tissue should be obtained by systematic random sampling and the cell counting should be performed using well-defined counting rules.

The cell profile counting was performed by using a probe called the counting frame. The counting frame consisted of a red and a green probe (lines). The red line is the exclusion line, while the green line is the inclusion line. The counting rules dictate that a cell is counted if it lies entirely within the counting frame or if it touches the inclusion line without touching the exclusion line. See Figure 8 for an illustration. 


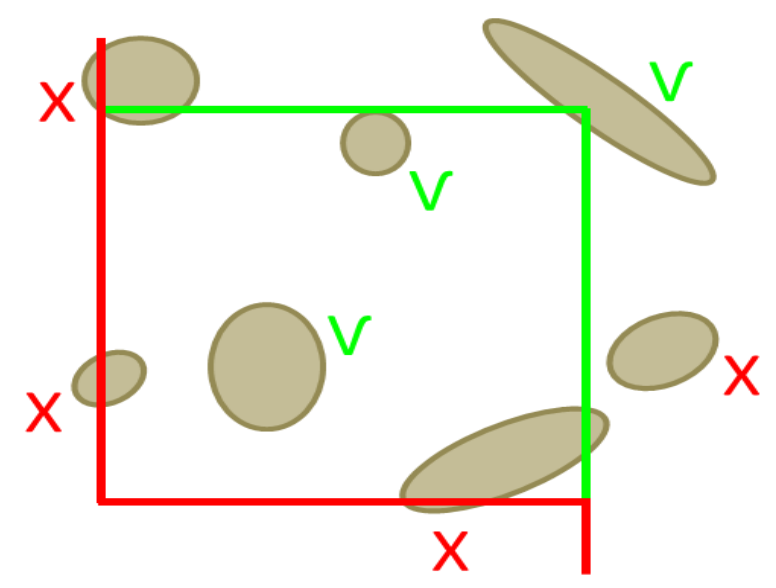

Figure 8. Simple illustration of a counting frame and 7 cell profiles. The red exclusion line extends to infinity. The $V$ marks show the cell profiles that are counted, and the crosses show the cell profiles that are not counted. There are 7 cell profiles in total, but only 3 are counted because 4 are touching the red exclusion line.

To evaluate all the sections, a microscope (Nikon ECLIPSE 80i) modified for stereology with a motorized stage and digital camera connected to a PC with newCAST 3.4.3.0 software (Visiopharm, Hørshold, Denmark) was used. For setup, see Figure 9. All sections were analyzed by the same investigator.

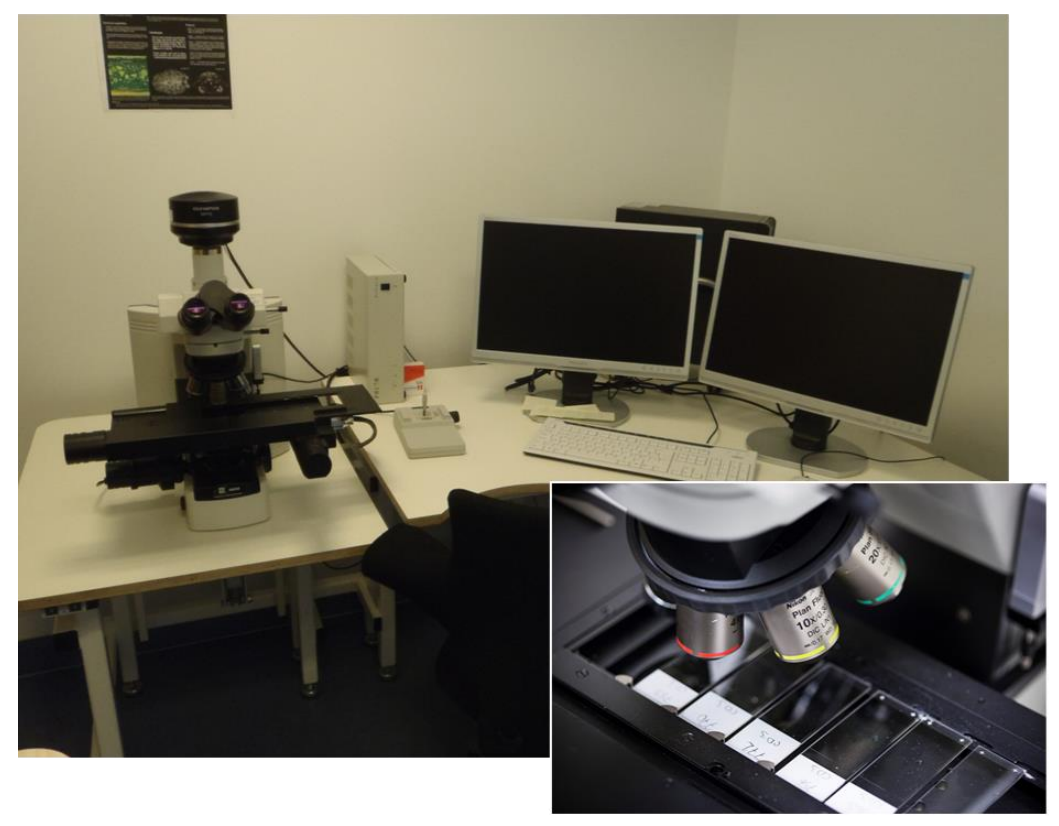

Figure 9. Workstation used for histological examination. Nikon Eclipse 80i microscope modified for stereology with a motorized stage and digital camera connected to a PC with newCast 3.4.3.0 software (Visiopharm, Hørsholm, Denmark). 


\section{Quantification of positive cell profiles}

A 2-dimensional quantification of CD3- and CD68-positive cell profiles was performed using the 2dimenational unbiased counting frame described above. Approximately 30 counting frames were placed systematically, evenly distributed and non-overlapping, over the sections by the software. For each counting frame, the numbers of CD3- and CD68-positive cell profiles were registered. Each counting frame covered an area of $383 \times 10^{3} \mu \mathrm{m}^{2}$. The counting was performed using a 20x lens. For a detailed description of the counting rules employed, see Figure 10 - 11.

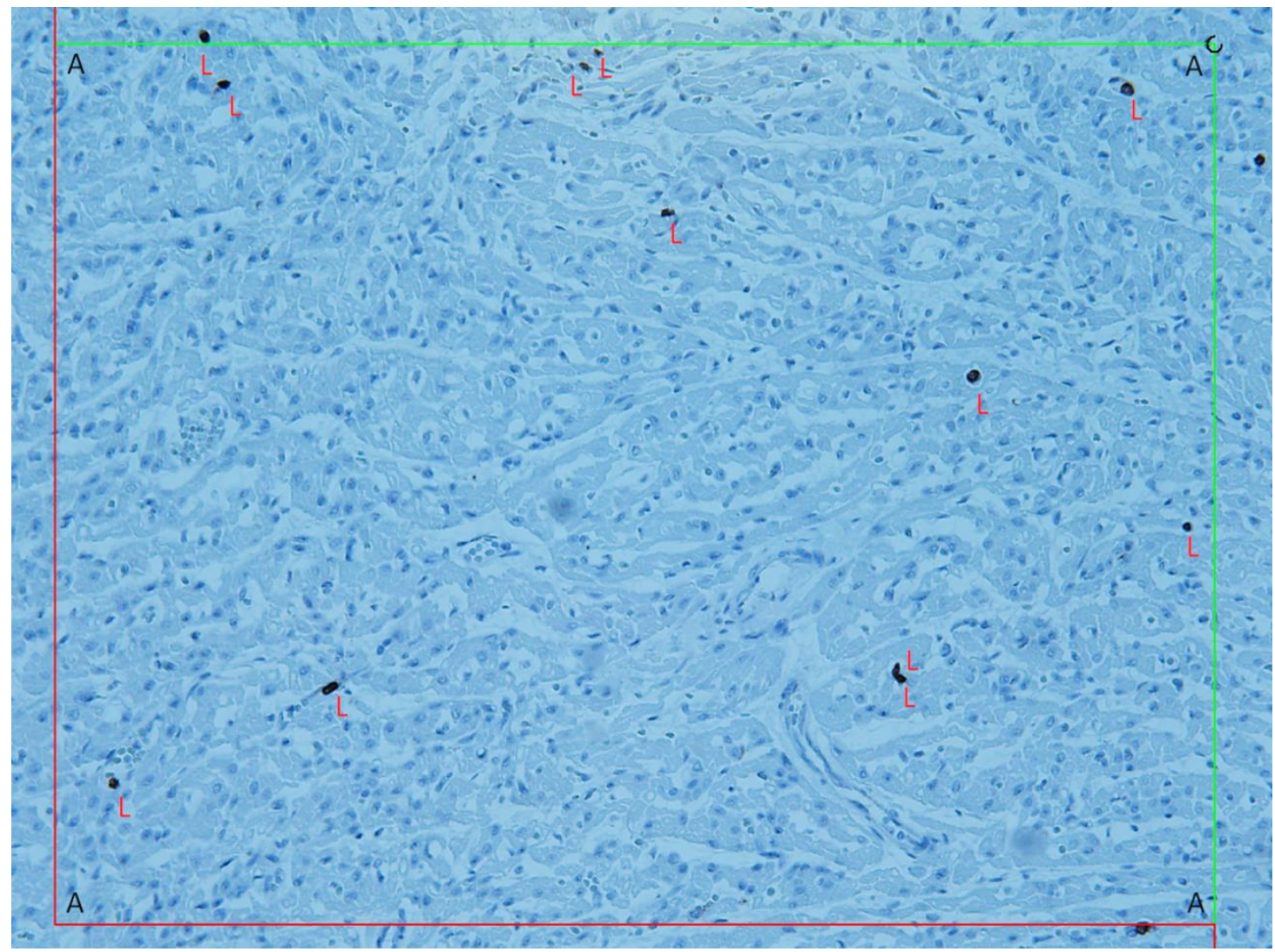

Figure 10. Light microscopic image of a heart section stained for T-lymphocytes (CD3) as observed with a 20x lens. Applied on the photo is a counting frame. For each field of view, cell profiles were counted as positive if they stained with $C D 3$ regardless of a nucleus was visible. Lymphocytes in regions of fibrosis were counted if they were identified as positive, while cells within the capillary lumen were not included. " $L$ " indicates each CD3-positive cell profile. " $A$ " indicates each corner of the counting frame used for point-counting the myocardium. 


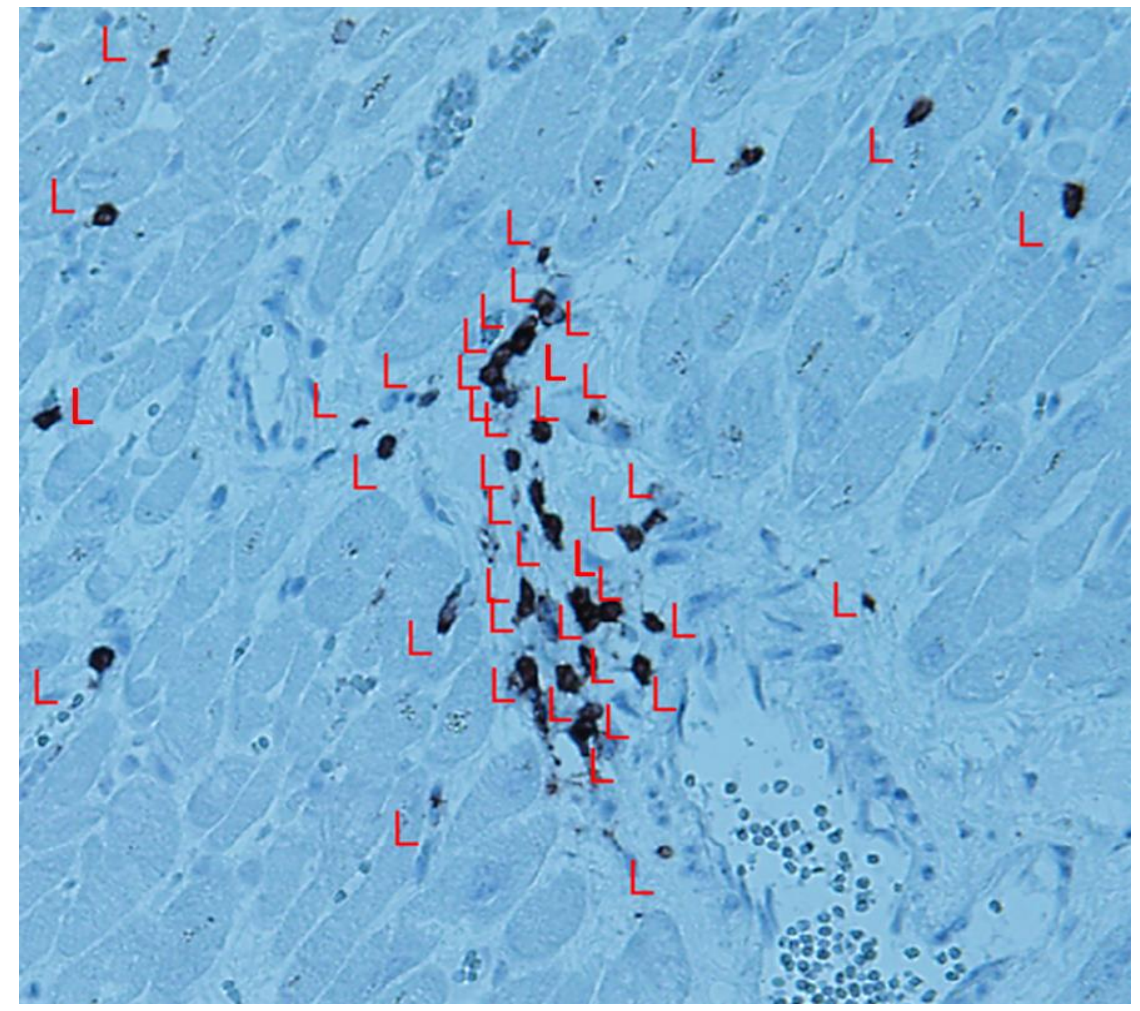

Figure 11. Light microscopic image of a heart section stained for T-lymphocytes (CD3) as observed with a 20x lens. A counting frame is not shown. The counting result in an area with a cluster of positive cell profiles is illustrated. " $\mathrm{L}$ " indicates each CD3 positive cell profile.

The total number of positive cell profiles per $\mathrm{mm}^{2}$ was in accordance with the fractionator principle calculated by the following formulas

$$
\begin{aligned}
& Q_{A}\left(\frac{C D 3}{M y o}\right)=\frac{\Sigma Q(C D 3)}{(a / p) \Sigma P(M y o)} \\
& Q_{A}\left(\frac{C D 68}{M y o}\right)=\frac{\Sigma Q(C D 68)}{(a / p) \Sigma P(\text { Myo })}
\end{aligned}
$$

where $\mathrm{Q}_{A}(\mathrm{CD} 3 / \mathrm{Myo})$ and $\mathrm{Q}_{A}(\mathrm{CD} 68 / \mathrm{Myo})$ were the total number of $\mathrm{CD3}$ - and CD68-positive cell profiles per $\mathrm{mm}^{2}$ myocardium, respectively; $\Sigma \mathrm{Q}(\mathrm{CD} 3)$ and $\Sigma \mathrm{Q}(\mathrm{CD} 68)$ were the sum of $C D 3$ - and 
CD68-positive cell profiles counted per section (e.g., sum of positive cell profiles in all counting frames), respectively; $(a / p)$ was the area of the counting frame divided by the number of test points (=4); and $\Sigma \mathrm{P}(\mathrm{Myo})$ was the sum of the counting frame corners hitting the myocardium.

\section{Intraobserver variability}

The stereological quantification data were evaluated for intraobserver variability by re-evaluating all sections from 20 randomly chosen hearts (10 projects and 10 controls). For re-evaluation, pictures of all counting frames were obtained during the first counting to ensure that the second counting was performed on the exact same areas. The time interval between the two evaluations was approximately 6 months. The primary aim of the intraobserver assessment was to evaluate the reproducibility of our results.

We did not perform standardized interobserver variation analysis on the stereological data.

Un-blinding was performed at the end of the stereological examinations.

\subsection{Studies II and III}

In studies II and III, virological analyses were performed for the presence of enterovirus, adenovirus, PVB19 and saffold virus. Analyses were performed on FFPE sections from four different locations, $A-D$, of the heart, as illustrated in Figure 3 in the material section.

\section{Extraction of DNA/RNA from FFPE tissue samples}

One $20 \mu \mathrm{m}$ section was cut by a microtome from each available FFPE tissue sample from each location, A-D. The working area and the microtome knife were kept clean with RNaseZap ${ }^{\mathrm{TM}}$ (Ambion), proline biocontrol (Biohit) and 99\% ethanol. Total nucleic acids were extracted from a mixture of sections from tissue location $A+B$ and $C+D$ using a customized protocol described previously ${ }^{116}$ that utilizes the automated magnetic bead-based Maxwell 16 system (Promega) in combination with proteinase $\mathrm{K}$ digestion and incubation in a lysis buffer. Two total nucleic extractions were performed for each case. For a detailed description of the DNA/RNA extraction, see Appendix B. 


\section{Detection of viral genomes}

The presence of enterovirus, adenovirus and PVB19 genomes in the total nucleic acids preparations was investigated using specific PCR and reverse-transcriptase PCR assays. Each virus detection assay was designed as a duplex real-time PCR assay targeting a virus-specific sequence and a human DNA or RNA region as an internal amplification control. Positive controls consisting of total nucleic acid preparations from known virus positive tissue samples were included in all three virus detection assays; for detailed description, see Appendix B. A case was considered positive if the viral genome was detected by PCR in at least one of two total nucleic acid extractions.

The presence of saffold virus genomes in total nucleic acids preparations was investigated using a specific reverse-transcriptase PCR assay, as previously described ${ }^{58}$. For the detection of saffold virus, the two total nucleic acids extractions were pooled, and one saffold virus-specific PCR analysis was performed.

\section{Serological examinations}

Serological analyses on stored blood samples were performed for PVB19-specific IgM and IgG antibodies in a subgroup of 110 cases (57 project cases and 53 control cases). Unfortunately, serological analyses were not possible for all cases due to missing blood samples. A diagram of the available samples for serological examinations is illustrated in Figure 12. 

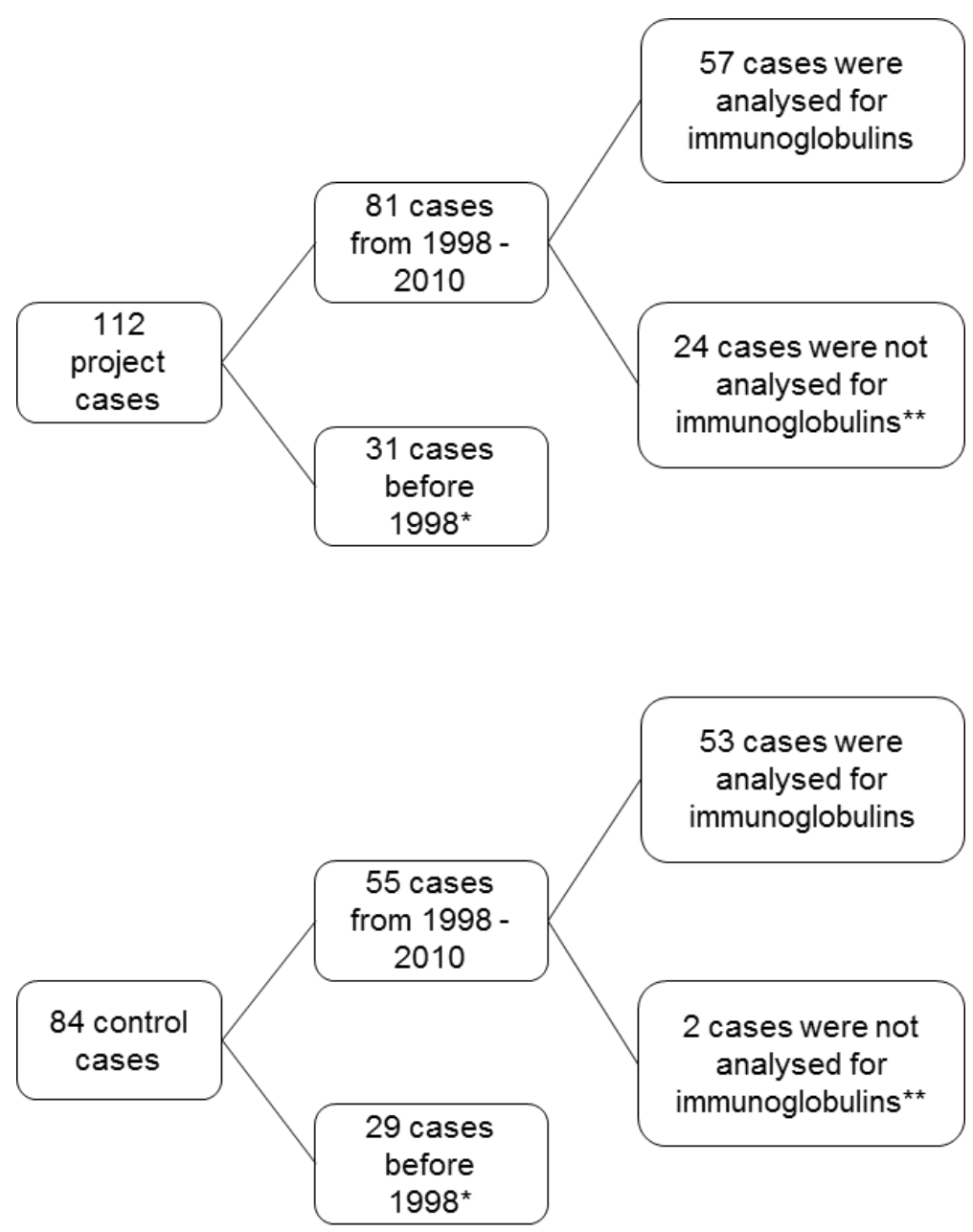

*Blood samples were only available from 1998 and forward

**Blood samples were either missing or the remaining blood volume was too small to perform the analysis

Figure 12. Availability of samples for serological investigation in the project group (upper) and the control group (lower).

PVB19-specific antibodies were measured using a commercial ELISA (Biotin, Ireland). IgM antibodies were measured by IgM capture, while IgG antibodies were measured by indirect ELISA. The assays were performed on a semiautomatic platform (Beb2000) following the manufacturer's protocol $^{117}$. The results were calculated following the manufacturer's guidelines.

\subsection{Examination of the excluded cases}

The histopathological re-evaluation according to the Dallas criteria performed in studies I and II led to the exclusion of 36 cases in the project group (36\%) and 16 cases in the control group (19\%), 
which corresponds to $21 \%$ of the samples and is a rather large percentage of the total study population. To examine the excluded cases more closely, all sections from the 54 excluded cases were subjected to further examination, where the histological findings of the original H\&E sections from the autopsy and the H\&E sections cut for this study were compared. The primary aim of this examination was to investigate the underlying reasons for a change in the diagnosis. 


\section{Statistics}

A descriptive analysis of the stereological data (mean, range and standard deviation) in both groups was performed. The non-parametric one-sided two samples Kolmogorov-Smirnov test was used to compare the lymphocyte profile counts between the two groups, because none of the datasets had a normal distribution. Diagnostic test performance (sensitivity and specificity) were assessed for different cut-off values. Sensitivity plus specificity were calculated for each possible cut-off value to identify the lymphocyte profile count per $\mathrm{mm}^{2}$ myocardium with the highest combined sensitivity and specificity.

Reproducibility of the stereological data was assessed using the Bland-Altman method of comparing repeated measurements ${ }^{118}$. Differences between measurements were tested by Student's paired samples t-test. Pearson's correlations coefficient was calculated.

$P$ values $<0.05$ were considered statistically significant. Data were analyzed by STATA 12.0 and $R$ software packages.

\section{Ethics and permissions}

The study was approved by the Danish National Ethical Committee protocol no. 1209317. All information concerning the deceased individuals was protected according to the applicable laws ("Lov om behandling af personoplysninger" and "Lov om patienters retsstilling"), and the project was reported to the Danish Data Protection Agency (Datatilsynet), journal no. 2010-41-4699 and 2014-41-2834. 


\section{Results}

\subsection{Epidemiological characteristics on the study subjects}

Epidemiological data for all the project and control cases are shown in Table 4. In the project group, $70 \%$ of all cases had symptoms prior to death, primarily consisting of infectious or cardiac symptoms. Three cases had a verified heart condition associated with cardiac inflammation. In addition, more than 50\% received medical treatment (predominantly antibiotics, anxiolytics, antidepressants and antipsychotics) at the time of death, and toxicological analysis revealed abuse of illicit drugs ion $14 \%$ of cases. In the control group, $46 \%$ received medical treatment (predominantly anxiolytics, antidepressants and antipsychotics) at time of death, and toxicological analysis revealed abuse of illicit drugs in $13 \%$ of cases. In general, the availability of the epidemiological data was inconsistent and inadequate in both groups. 


\begin{tabular}{|c|c|c|c|c|c|c|}
\hline & \multicolumn{3}{|c|}{ Project group $n=112(\%)$} & \multicolumn{3}{|c|}{ Control group $n=84(\%)$} \\
\hline & Yes & $\mathrm{No}^{\mathrm{a}}$ & Unknown $^{\mathrm{b}}$ & Yes & $\mathrm{No}^{\mathrm{a}}$ & Unknown $^{\mathrm{b}}$ \\
\hline Symptoms prior to death, overall & $78 / 112(70)$ & $4 / 112(3)$ & $30 / 112(27)$ & $45 / 84(54)$ & $7 / 84(8)$ & 32/84 (38) \\
\hline Symptoms of infection & $37 / 78(47)$ & None & $41 / 78(53)$ & None & None & $45 / 45(100)$ \\
\hline Respiratory system & $13 / 37(35)$ & - & - & - & - & - \\
\hline Gastrointestinal system & 9/37 (24) & - & - & - & - & - \\
\hline Other locations & $15 / 37(41)$ & - & - & - & - & - \\
\hline Cardiac symptoms & 22/78 (28) & None & $56 / 78(72)$ & None & None & $45 / 45(100)$ \\
\hline Chest pain & $12 / 22(55)$ & - & - & - & - & - \\
\hline Dyspnea & $9 / 22(41)$ & - & - & - & - & - \\
\hline Palpitations & $1 / 22(4)$ & - & - & - & - & - \\
\hline Psychological discomfort & None & None & $78 / 78(100)$ & $42 / 45(93)$ & $3 / 45(7)$ & None \\
\hline Autoimmune disorders & $1 / 112(<1)$ & $55 / 112(49)$ & $56 / 112(50)$ & None & None & $84 / 84(100)$ \\
\hline Medical treatment & $61 / 112(54)$ & $14 / 112(13)$ & $37 / 112(33)$ & $39 / 84(46)$ & $11 / 84(12)$ & $34 / 84(40)$ \\
\hline Antipsychotics & $7 / 61^{\star}(11)$ & $24 / 61(40)$ & $30 / 61(49)$ & $9 / 39(23)$ & $16 / 39(41)$ & $14 / 39(36)$ \\
\hline Anti-depressants & $9 / 61(15)$ & 23/61 (38) & $29 / 61(47)$ & $18 / 39(46)$ & $12 / 39(31)$ & $9 / 39(23)$ \\
\hline Immunosuppressive & $1 / 61(2)$ & None & $60 / 61(98)$ & None & None & $39 / 39(100)$ \\
\hline Drug abuse (illicit drugs) & $16 / 112(14)$ & $73 / 112(65)$ & $23 / 112(21)$ & $11 / 84(13)$ & $48 / 84(57)$ & 25/84 (30) \\
\hline Cocaine & 2/16 (12) & $14 / 16(87)$ & - & $2 / 11(18)$ & $9 / 11(97)$ & - \\
\hline \multicolumn{7}{|l|}{ Other conditions } \\
\hline Sepsis (verified bacterial focus) & $9 / 112(8)$ & $103 / 112(92)$ & None & None & $84 / 84(100)$ & None \\
\hline Cardiac transplant & $1 / 112(<1)$ & $111 / 112(99)$ & None & None & $84 / 84(100)$ & None \\
\hline Artificial cardiac valve & $1 / 112(<1)$ & $111 / 112(99)$ & None & None & $84 / 84(100)$ & None \\
\hline ARVC (verified genetic mutation) & $1 / 112(<1)$ & None & $111 / 112(99)$ & None & $84 / 84(100)$ & None \\
\hline
\end{tabular}

${ }^{\mathrm{a}}$ Confirmed negative information; ${ }^{b}$ No information

*One case treated with clozapine at the time of death; ${ }^{* *}$ Confirmed by toxicological analysis performed in $89 / 112$ project cases and $59 / 84$ control cases

Table 4. Characteristics of project and control cases. 


\subsection{Characterization of inflammatory infiltrations}

The inflammatory changes were characterized by the most predominant cell type, and the results are shown in Figure 13.

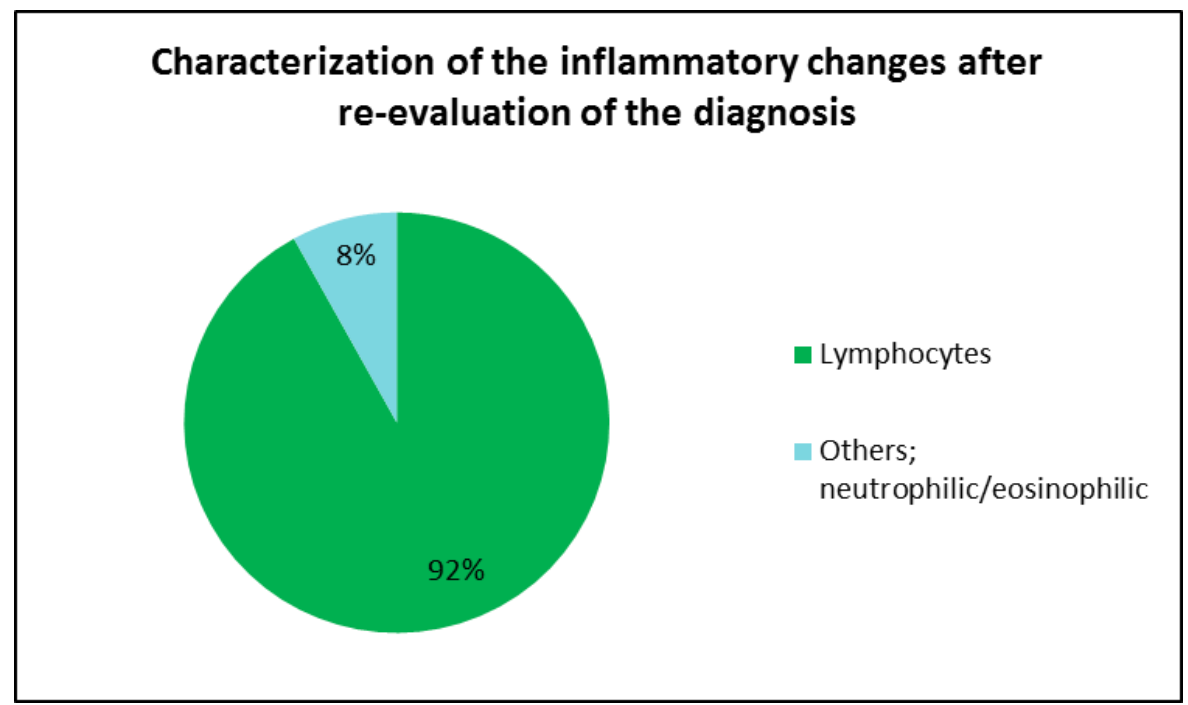

Figure 13. Characterization of the inflammatory changes based on the most predominant cell type.

As observed, lymphocytic myocarditis was the most prevalent type of myocarditis in this study; the inflammatory changes in $92 \%$ of cases primarily consisted of lymphocytes, while only $8 \%$ of cases had either neutrophilic or eosinophilic granulocytes as the predominant cell type.

\subsection{Interobserver variability}

Interobserver variability of the results obtained at re-evaluation was assessed by calculating Cohen's kappa, which is a measure of inter-rater agreement adjusted for the amount of agreement that would be expected by chance. The kappa coefficient is scaled to be 0 when the amount of agreement is what would be expected by chance and 1 when there is perfect agreement. For intermediate values Landis and Koch have suggested the following interpretations $^{119}$ : 
Below 0.00: Poor agreement

$0.00-0.20$ : Slight agreement

$0.21-0.40$ : Fair agreement

0.41 - 0.60: Moderate agreement

$0.61-0.80:$ Substantial agreement

$0.81-1.00:$ Almost perfect agreement

The results of the interobserver variability are shown in Table 5 and 6.

\begin{tabular}{l|ll|l} 
& \multicolumn{2}{|c}{ Observer 2 } \\
Observer 1 & $\begin{array}{l}\text { Inflammatory } \\
\text { infiltration not present }\end{array}$ & $\begin{array}{l}\text { Inflammatory } \\
\text { infiltration present }\end{array}$ & 76 \\
\hline $\begin{array}{l}\text { Inflammatory } \\
\text { infiltration not present } \\
\begin{array}{l}\text { Inflammatory } \\
\text { infiltration present }\end{array}\end{array}$ & 68 & 8 & 24 \\
\hline Total & 5 & 19 & 100
\end{tabular}

Table 5. Results of the interobserver assessment.

\begin{tabular}{l|l|l} 
Agreement & Expected agreement & Kappa \\
\hline $87.00 \%$ & $61.96 \%$ & 0.6583 \\
\hline
\end{tabular}

Table 6. Calculation of Cohen's kappa in the assessment of interobserver variability.

We found a kappa coefficient on 0.66 corresponding to substantial agreement, i.e., the primary investigators' skills in identifying inflammatory infiltrations according to the established criteria were considered satisfactory. 


\subsection{Study I}

\section{$\underline{\text { Quantification of CD3-positive cell profiles }}$}

The number of $\mathrm{CD} 3$ positive lymphocyte profiles per $\mathrm{mm}^{2}$ was estimated in 196 deceased individuals (112 project cases; 84 control cases) by systematic sampling of field of views and a stereological profile counting method. The results are shown in Figure 14.

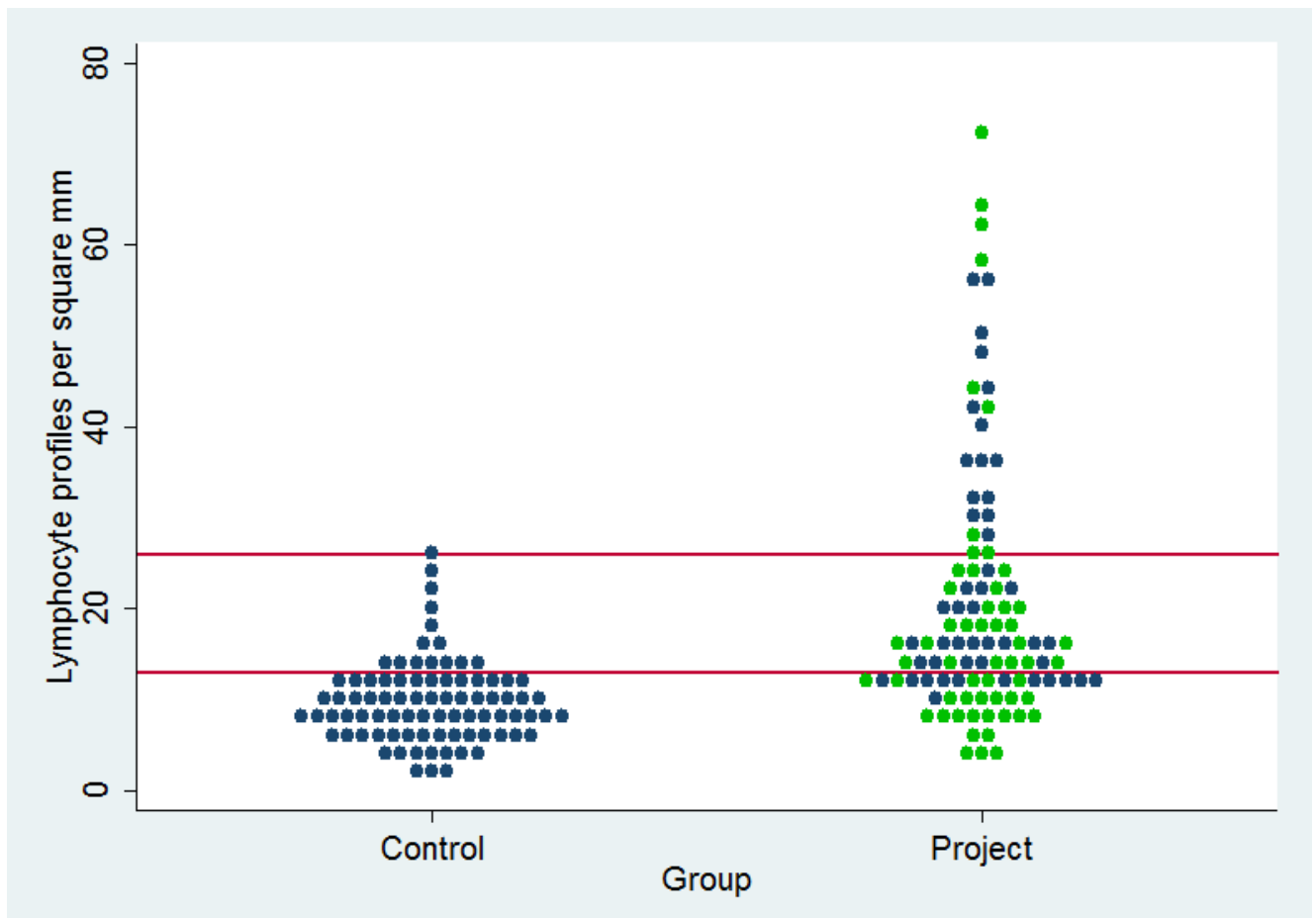

Figure 14. Dot plot of lymphocyte profiles per $\mathrm{mm}^{2}$ for project cases and control cases. Horizontal reference lines are added at 13.0 lymphocyte profiles per $\mathrm{mm}^{2}$ (lower) and 25.9 lymphocyte profiles per $\mathrm{mm}^{2}$ (upper). Nine cases in the project group with $\geq 100$ lymphocyte profiles per $\mathrm{mm}^{2}$ (124946 lymphocyte profiles per $\left.\mathrm{mm}^{2}\right)$ ) have been excluded for clarity of the lower part of the figure. The green dots represent cases in which myocarditis is stated as the cause of death in the autopsy files, which includes all 9 cases excluded from this figure.

The mean number of lymphocyte profiles per $\mathrm{mm}^{2}$ was 52.71 (range 3.69 - 946.0; standard deviation 131.86) in the project group and 9.74 (range 2.1 - 25.89; standard deviation 4.62) in the control group. The difference between groups was analyzed using the one-sided two-sample Kolmogorov-Smirnov test. The $p$ value was $<0.0001$, indicating a highly significant difference. 
In the project group, substantial variation was found in the lymphocyte profile count in comparison to the control group, indicating that the inflammatory findings were both sparse and pronounced. However, for both groups, the majority of cases had lymphocyte profile counts below 30 per $\mathrm{mm}^{2}$. According to the autopsy files, the causes of death were myocarditis in 65/112 (58\%) cases in the project group. As seen in Figure 14, deaths were attributed to myocarditis among cases with high cell profile counts as well as low cell profile counts.

\section{no. true possitive}

To assess diagnostic accuracy, sensitivity $=\overline{\text { no.true possitive }+ \text { no.false negative }}$ and no. true negative

specificity = (no.true negative + no.false positive were estimated for different possible cut-off values from $5-25$ lymphocyte profiles per $\mathrm{mm}^{2}$ and specificity plus sensitivity were calculated with corresponding 95\% pointwise confidence bounds. The results are shown in Figure 15. 


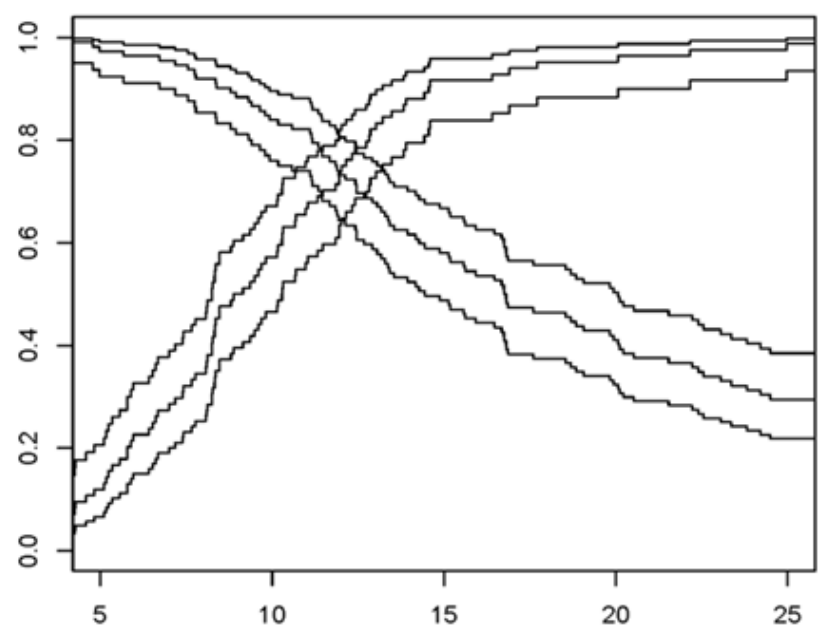

sensitivity plus specificity

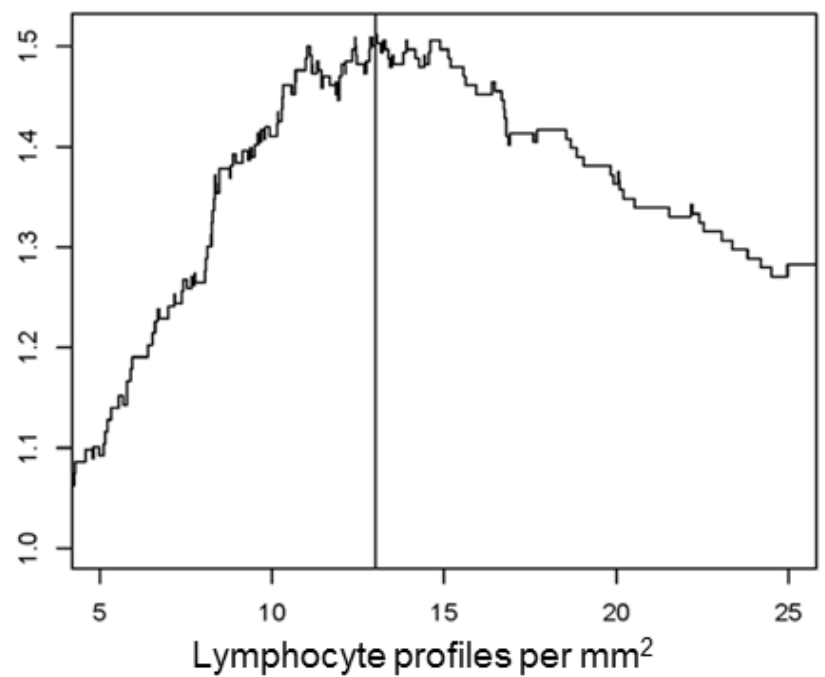

Figure 15. Upper panel: Estimated sensitivity (decreasing curve) and specificity (increasing curve) at different cut-off values from 5 - 25 lymphocyte profiles $/ \mathrm{mm}^{2}$ (x-axis) with $95 \%$ pointwise confidence bounds (envelops). Lower panel: Estimated sensitivity plus estimated specificity at different cut-off values from 5 - 25 lymphocyte profiles $/ \mathrm{mm}^{2}$ (x-axis). The vertical line is placed at the maximum sensitivity plus specificity, indicating a cut-off value $=13.0$ lymphocyte profiles $/ \mathrm{mm}^{2}$.

The highest combined sensitivity and specificity was observed at a cut-off value of 13 lymphocyte profiles per $\mathrm{mm}^{2}$ which had a sensitivity of $68 \%$ and specificity of $83 \%$. In other words, at this cutoff level, 76 of the 112 myocarditis cases would get a positive diagnosis (true positive), while 36 would get a negative diagnosis (false negative). In the control group, 70 of the 84 non-myocarditis cases would get a negative diagnosis (true negative), while 14 would get a positive diagnosis (false 


\section{no. true possitive}

positive). The positive predictive value $=\overline{\text { no. true possitive }+ \text { no.false positive }}$ is $84 \%$ no. true negative

and the negative predictive value $=\overline{\text { no. true negative + no. false negative }}$ is $66 \%$.

The sensitivity-specificity curve (Figure 15 lower panel) flattens (i.e., is approximately horizontal) between 11 - 16 lymphocyte profiles per $\mathrm{mm}^{2}$, indicating that a cut-off value could be chosen at any point within this interval without significantly changing the overall sensitivity plus specificity.

\section{$\underline{\text { Quantification of } \mathrm{CD} 68 \text { positive cell profiles }}$}

Quantifying CD68-positive cell profiles was very difficult even though the CD68-stained sections were subjected to the same counting rules as the CD3-stained sections. The morphology of macrophages is not as homogeneous as lymphocytes, and they tend to organize in clusters rather than discrete cells, which made identification and separation of each CD68-positive cell profile challenging. The quantification was furthermore complicated by the background staining. For illustrations, see Figure 16 - 18. Consequently, we considered it impossible to perform a reliable and reproducible cell profile count and thus an estimation of the total number of CD68-positive cell profiles per $\mathrm{mm}^{2}$ myocardium, despite well-defined counting rules. The CD68-stained sections were rejected from further examinations in this study. 

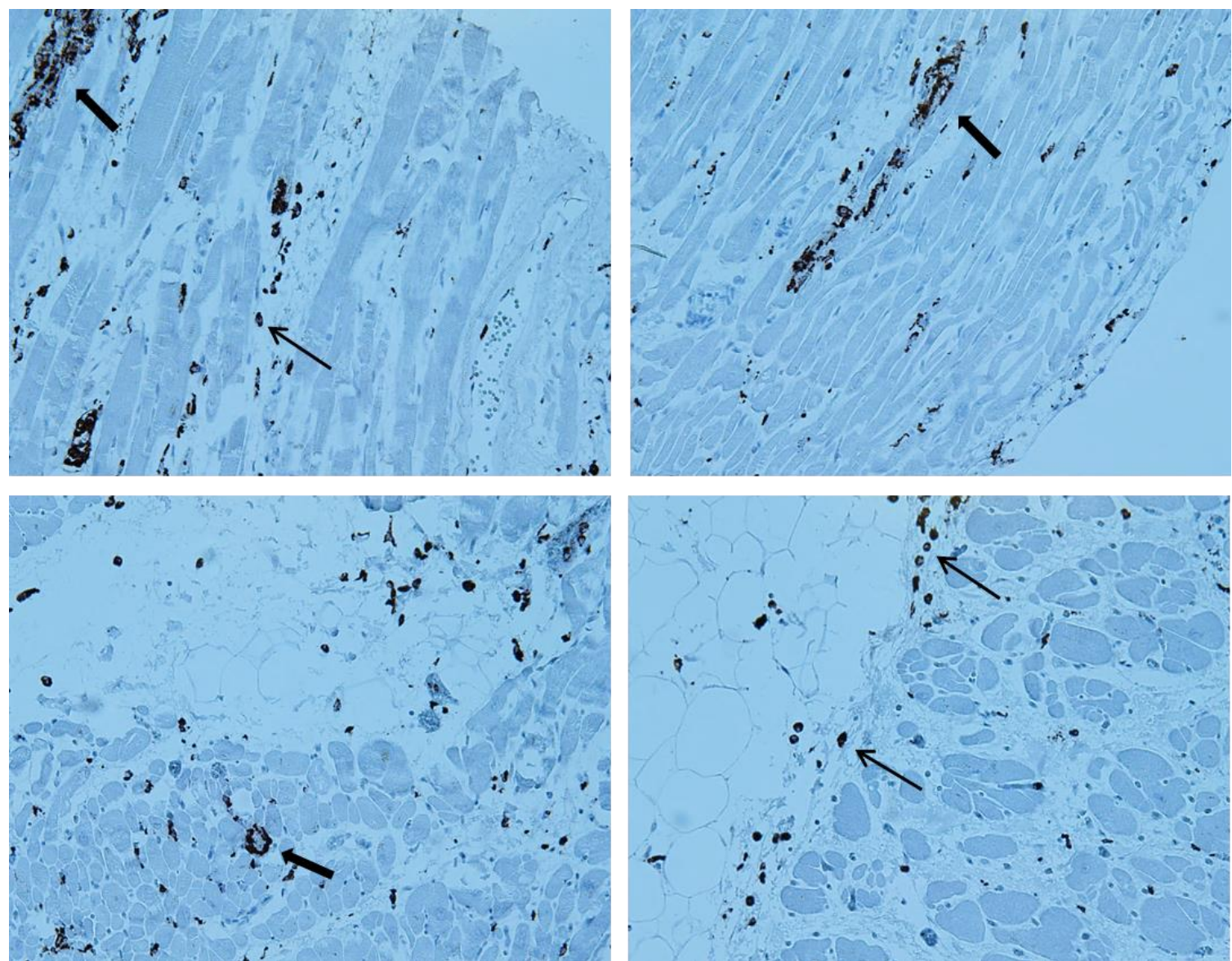

Figure 16. Light microscopic image of four heart sections stained for macrophages (CD68) as observed with a 20x lens. Counting frames are not shown. Identification and separation of each positive cell profile are possible in some areas (thin arrows), while other areas are characterized by clusters of positive cell profiles that make a reliable cell profile count impossible (thick areas). 

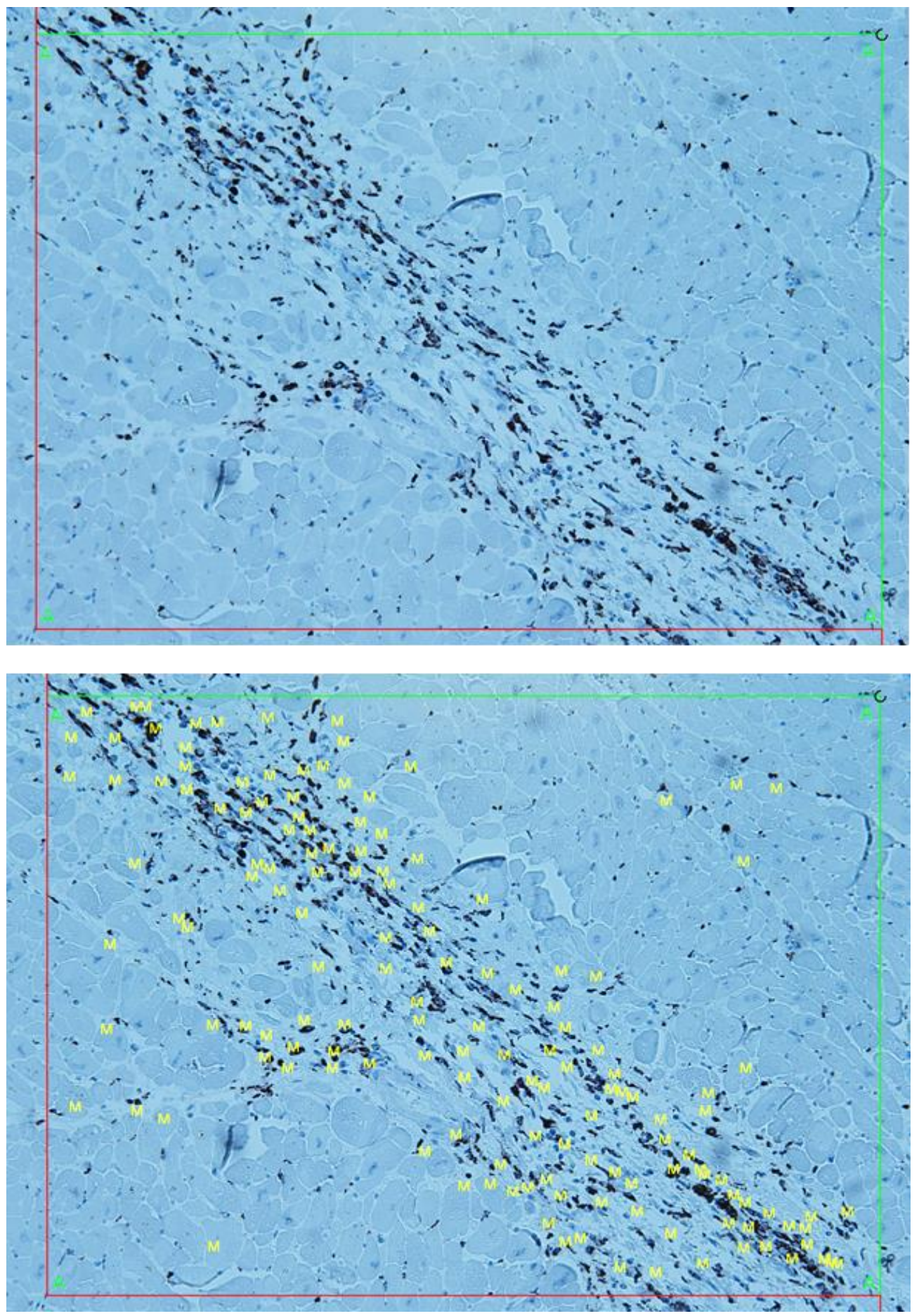

Figure 17. Two light microscopic images of the same heart section stained for macrophages (CD68) as observed with a 20x lens, one with an attempt to indicate each positive cell profile (lower) and one without (upper). This figure reflects the difficulties in separating positive cell profiles despite well-defined counting rules. " $M$ " indicates each CD68-positive cell profile. " $A$ " indicates each corner of the counting frame used for point-counting the myocardium. 


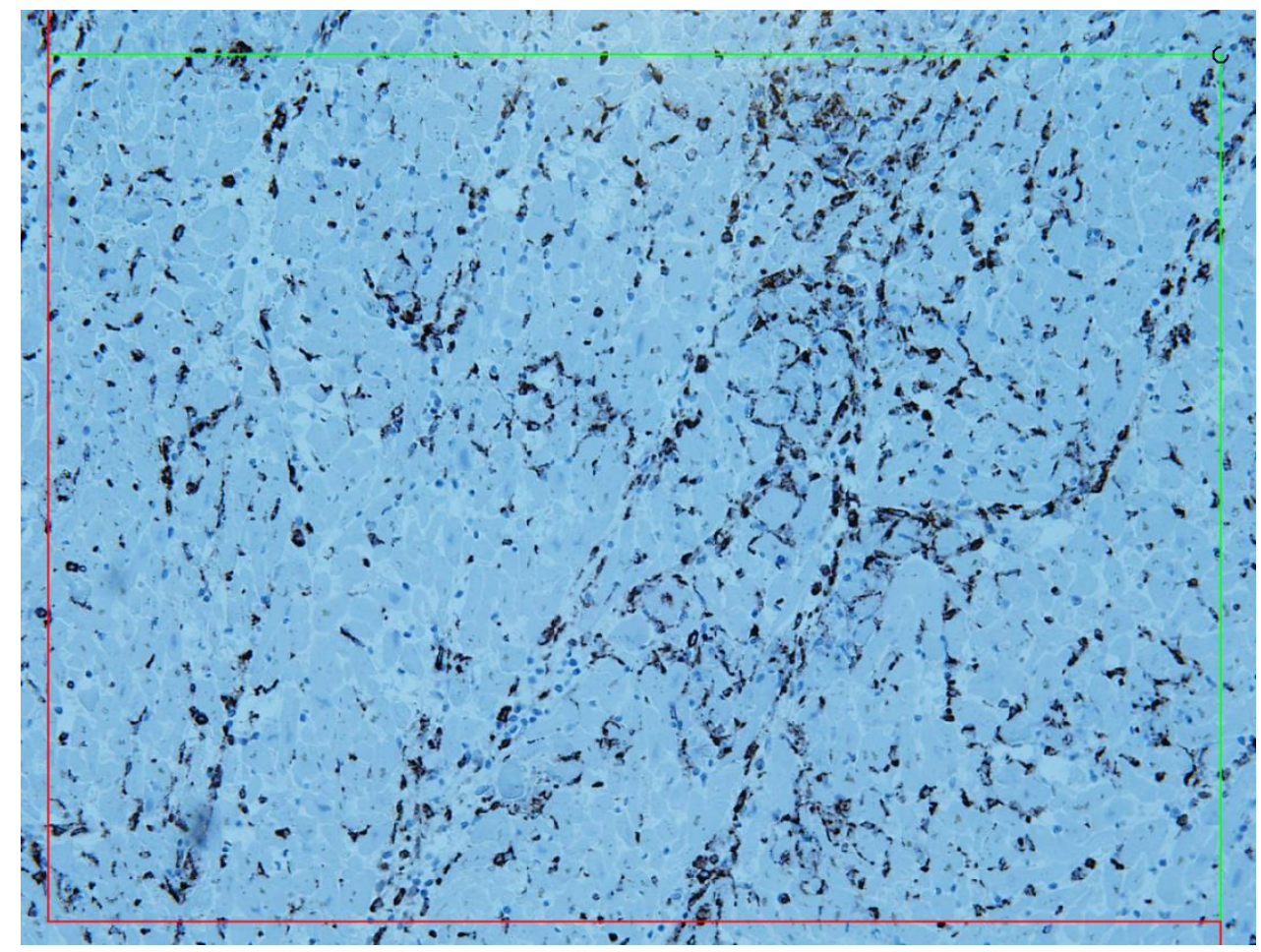

Figure 18. Light microscopic image of a heart section stained for macrophages (CD68) as observed with a 20x lens. Numerous positive cell profiles are distributed throughout the tissue sample. Several clusters of positive cell profiles are present. A reliable identification of each positive cell profile is impossible.

\section{Intraobserver variability of the stereological data}

According to the Bland-Altman method for comparing repeated measurements, $95 \%$ of the

differences between two paired measurements should be less than $\pm 1.96 *$ SD (standard deviation), also known as the limits of agreement. Furthermore the difference should not differ significantly from zero because the same method is used for both assessments. The result is shown in Figure 19. 

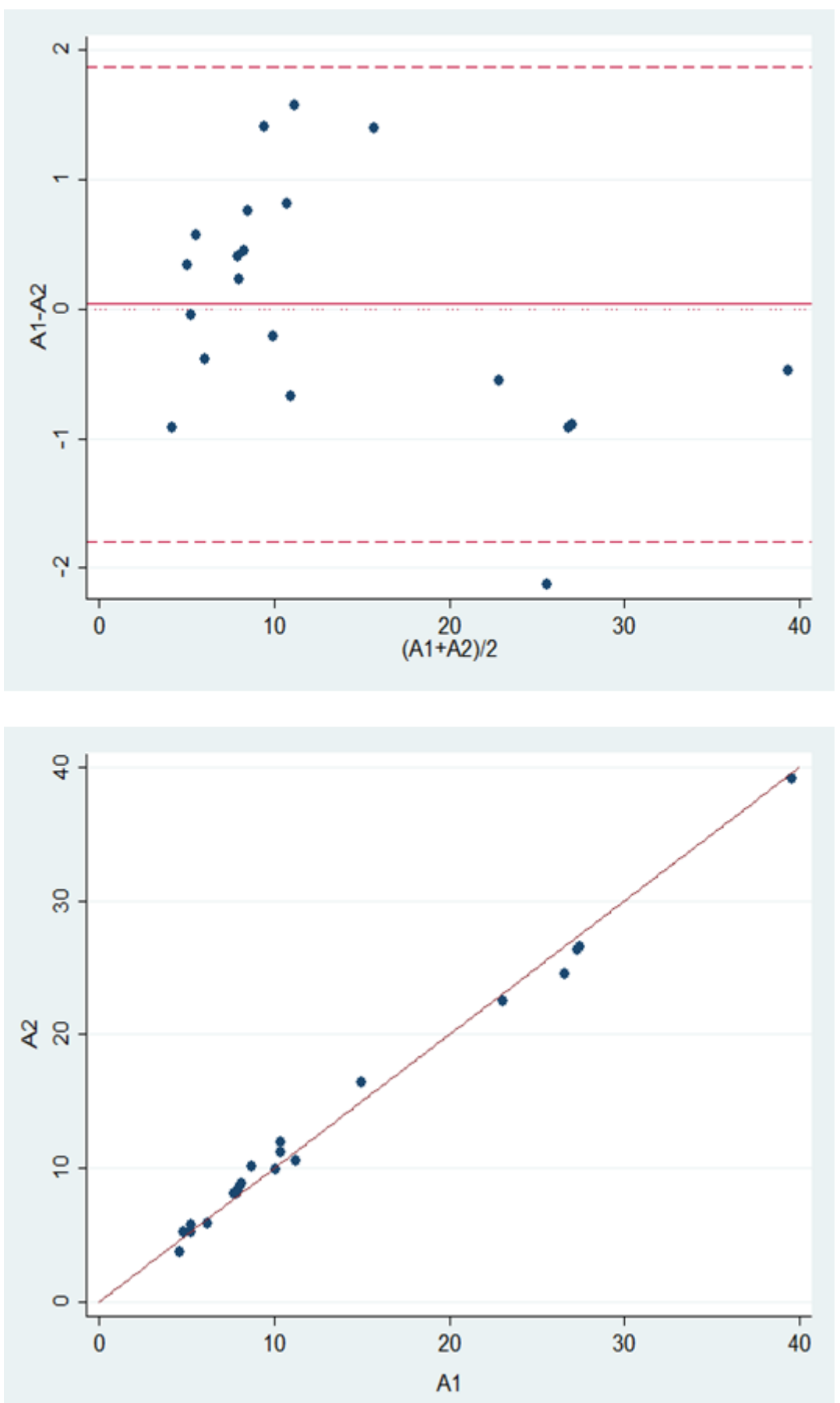

Figure 19. Analysis of intraobserver variability. Upper: Bland-Altman plot showing the average lymphocyte profiles per $\mathrm{mm}^{2}$ (x-axis) in relation to the difference between the first (A1) and second (A2) lymphocyte profile count (y-axis). The dashed red lines represent $95 \%$ limits of agreement, and the dotted line signifies $y=0$. Lower: Correlation plot between the first and second count. Pearson's correlation coefficient between $A 1$ and A2 was 0.996, indicating that the two measurements are highly correlated.

As observed, the intraobserver variability was within the limits of agreements in all but one case. The two measurements were compared for difference in mean using a Student's paired samples t- 
test. This test yielded $p=0.86$, indicating no difference in mean, i.e., there were no significant difference in the lymphocyte profile counts between the two measurements.

\subsection{Studies II and III}

\section{Results of the virological examinations}

PVB19 genomes were detected by PCR in 33 of the 112 project cases and in 37 of the 84 control cases. Enterovirus and adenovirus were not detected in any of the project or control cases. Saffold virus was detected in 1 of 150 project cases. The results of the PCR analyses are shown in Table 7.

\begin{tabular}{lcc}
\hline & Project cases & Control cases \\
\hline Enterovirus & 0 & 0 \\
Adenovirus & 0 & 0 \\
Parvovirus B19 & $33 / 112(29)$ & $37 / 112(44)$ \\
Saffold virus & $1^{*} / 150(<1)$ & - \\
\hline $\begin{array}{l}\text { Values are } n(\%) \\
\text { This case was also examined for the presence of saffold virus in other non-cardiac samples with a positive } \\
\text { result in respiratory secretion and blood. }\end{array}$
\end{tabular}

Table 7. Results of PCR analyses for enterovirus, adenovirus, parvovirus B19 and saffold virus in project and control cases.

The internal amplification control analysis revealed that PCR amplification of DNA was possible in $99 \%(111 / 112)$ of project cases, while amplification of a human control mRNA was possible in $91 \%$ $(102 / 112)$ of the project cases. 


\section{Serological analyses for parvovirus B19 specific immunoglobulins}

The results of the serological analyses are shown in Table 8.

\begin{tabular}{lcc}
\hline Project cases, $\mathbf{n = 5 7}$ & $\begin{array}{c}\text { Parvovirus B19- } \\
\text { positive }^{*}\end{array}$ & $\begin{array}{c}\text { Parvovirus B19- } \\
\text { negative* }^{*}\end{array}$ \\
\hline $\lg \mathrm{M}+$ / lgG+ & 0 & 0 \\
$\lg \mathrm{M}_{+} / \lg \mathrm{lg}-$ & 1 & 0 \\
$\operatorname{lgM}-$ / lgG+ & 17 & 19 \\
$\operatorname{lgM}$ - / lgG- & 1 & 18 \\
Inconclusive test & 0 & 1 \\
\hline Total & $\mathbf{1 9}$ & $\mathbf{3 8}$ \\
\hline
\end{tabular}

\begin{tabular}{lcc}
\hline Control cases, $\mathbf{n = 5 3}$ & $\begin{array}{c}\text { Parvovirus B19- } \\
\text { positive }^{*}\end{array}$ & $\begin{array}{c}\text { Parvovirus B19- } \\
\text { negative }^{*}\end{array}$ \\
\hline $\operatorname{lgM}+$ / lgG+ & 0 & 0 \\
$\operatorname{lgM}+$ / lgG- & 0 & 0 \\
$\operatorname{lgM}$ - / lgG+ & 22 & 11 \\
$\operatorname{lgM}$ - / lgG- & 4 & 14 \\
Inconclusive test & 2 & 0 \\
\hline Total & $\mathbf{2 8}$ & $\mathbf{2 5}$ \\
\hline
\end{tabular}

Values are $\mathrm{n}$;

*Results of the examination for parvovirus B19 in the myocardium by PCR.

Table 8. Results of the serological analyses in the project group (upper) and the control group (lower).

In the project group positive PVB19 IgM titers were detected in one case. In this case, PVB19 was also detected in the myocardium. Thirty-six of 57 (63\%) cases had a positive PVB19 IgG titer, while 19 of 57 (33\%) cases had a negative IgG titer. In one case, both IgG and IgM were negative, despite a positive PVB19 PCR in the myocardium.

In the control group, 33 of 53 (62\%) cases had a positive IgG titer, while 18 of 53 (34\%) cases had a negative IgG titer, which is a similar distribution as seen in the project group. IgM was not detected in any of the control subjects. Four cases presented with a negative IgM and IgG titer despite a positive PVB19 PCR. 


\subsection{Examination of the excluded cases}

The results of the histopathological examination on both the original sections obtained at autopsy and the sections cut for the purpose of this study were compared to determine the underlying cause of a change in the diagnosis, which led to the exclusion of 56 cases.

Thirty-eight cases were excluded from the project group because no inflammation could be detected at re-evaluation. When re-examining the original sections from the autopsy, inflammation were present in 21 of 38 cases. In these 21 cases, the changes in the diagnosis at reevaluation were not caused by an incorrect diagnosis made at autopsy but rather as a result of cutting beyond the inflamed areas when cutting new section for this study. Of the remaining 17 cases, the original sections could not be re-examined in 13 cases because these sections had been discarded. In 4 cases, the changes in the diagnosis were either due to an incorrect diagnosis made at autopsy or the use of diagnostic criteria other than those defined for this study.

Sixteen cases were excluded from the control group because inflammation was detected at reevaluation. When re-examining the original sections from the autopsy, no inflammation was found in 7 of 16 cases. In these 7 cases, the changes in the diagnosis at re-evaluation were not caused by an incorrect diagnosis made at autopsy but rather as a result of cutting into inflamed areas when cutting new section for this study. Of the remaining 9 cases, the original sections could not be reexamined in 4 cases, because these sections had been discarded. In 5 cases, the changes in the diagnosis were either due to an incorrectly diagnosis made at autopsy or the use of diagnostic criteria other than those defined for this study.

To summarize, the changes in diagnosis at re-evaluation were considered primarily to be a result of technical circumstances with sampling error (cutting into or cutting beyond the inflamed areas) rather than an incorrect diagnosis made at autopsy. However, a detailed evaluation on the accuracy of the myocarditis diagnosis made at autopsy was not a purpose of this study. 


\section{Discussion}

\subsection{Interpretation of the results}

\section{Quantitative diagnostic criteria for myocarditis - study I}

Study I was designed to quantitatively estimate and compare the presence of lymphocytes and macrophages in subjects with myocarditis and control subjects, thereby enabling us to create reliable quantitative criteria for the diagnosis of lymphocytic myocarditis in autopsy specimens. Using a systematic sampling of field of views and a stereological cell profile counting method, we aimed to reduce the subjectivity of the histopathological examination, which we believe constitutes an important limitation of the previously published studies.

\section{Lymphocytes}

We found that the mean number of lymphocyte profiles per $\mathrm{mm}^{2}$ was 52.71 (range $3.69-946.0$; standard deviation 131.86) in the project group and 9.74 (range 2.1 - 25.89; standard deviation was 4.62) in the control group. The results in the control group are higher than reported by others $^{104,105,107,109}$. Whereas the previously reported studies are mainly based on smaller study cohorts and use EMBs from patients with cardiac diseases other than myocarditis as control subjects, we intentionally selected non-inflamed myocardial specimens for this study and therefore expected to find a lower lymphocyte profile count. The differences in the results observed between this study and those previously reported may have several explanations. As illustrated in Table 4, at least $46 \%$ of our control subjects received medical treatment at the time of death and $19 \%$ were abusing illicit drugs, which may have contributed to an elevated lymphocyte profile count in the myocardium ${ }^{62-65,67}$. Furthermore, differences in the size of the study cohorts, sampling of material and the applied method may be important factors. In this study, the lymphocyte number was estimated in a large control group and included large-sized transmural postmortem tissue samples from different parts of the heart, which is an advantage compared with most other studies based on the use of smaller biopsies taken in vivo. Furthermore, the histopathological examination in this study utilized a low-biased stereological cell profile counting method. 
We calculated sensitivity and specificity for each possible cut-off value and used the highest combined result to identify the cell profile count per $\mathrm{mm}^{2}$ myocardium with the highest diagnostic accuracy. We obtained a cut-off value of 13 lymphocyte profiles per $\mathrm{mm}^{2}$ (sensitivity 68\%; specificity $83 \%$ ), which supports the recommendations of Maisch et al ${ }^{106}$. However, our results are based on a different type of background. If we apply the suggestions of Maisch et al. and use a lymphocyte count of 2 standard deviations above what is found in normal tissue as the cut-off value, the cut-off value for our control data would be 19 lymphocyte profiles per $\mathrm{mm}^{2}$. As shown in Figure 15, using this cut-off value substantially decreases the sensitivity from $68 \%$ to $43 \%$, increases the specificity from $82 \%$ to $95 \%$ and reduces the overall sensitivity plus specificity. Furthermore, an assumption of two standard deviations as a reliable cut-off value to correctly diagnose the majority of myocarditis cases requires a normal distribution of the lymphocyte profile count in normal tissue. The lymphocyte profile count in our control cases was not normally distributed (left-skewed distribution).

The mean lymphocyte profile count in the project and the control groups proved to be significantly different $(p=0.0001)$, but a more interesting finding is the distribution of cell counts between the groups. A considerable part of the deceased individuals in both the project and the control groups had lymphocyte profile counts below 30 per $\mathrm{mm}^{2}$ (Figure 14). Consequently, the risk of creating false negative or false positive results at low lymphocyte counts is high. We believe that this group of individuals with low lymphocyte profile counts represents a diagnostic challenge because a diagnosis based solely upon lymphocyte count in these cases may lead to an unreliable diagnosis of myocarditis. As shown in Figure 14, 24 of the 36 (66\%) deceased individuals with lymphocyte profile counts below 13 per $\mathrm{mm}^{2}$ in the project group had myocarditis stated as the cause of death, which highlights the importance of identifying and diagnosing this group correctly to establish the right cause of death. In the criteria suggested by Maisch et al a diagnosis of myocarditis could also be made when $\geq 3$ lymphocyte profiles are present in nests, even if the criterion of 14 lymphocyte profiles per $\mathrm{mm}^{2}$ is not reached. This extension of the criteria would most likely enable a correct diagnosis for some of the cases with low lymphocyte profile counts. However, small inflammatory foci with or without myocyte necrosis has been demonstrated as a common incidental finding at autopsy, including traumatic and non-cardiac deaths ${ }^{67,102}$ and suicidal cases as presented in this study (excluded cases in the control group). Thus, we think that 
the separation of myocarditis and incidental inflammatory findings based on the presence of nest(s) of $\geq 3$ lymphocyte profiles is unreliable.

\section{Macrophages}

In this study, we demonstrated that the identification and counting of CD68 positive macrophages profiles in the myocardium is highly problematic. Although we refrained from including the macrophage counts in our results, we find our methodological experience of great importance, because a quantitative criterion including up to 4 macrophages per $\mathrm{mm}^{2}$ is included in the latest diagnostic recommendations of myocarditis made by Maisch et al. In previously published studies, a quantitative assessment of macrophages has been reported ${ }^{67,107,108,110,111}$, but detailed counting rules have not been described, which makes an evaluation of the results impossible. Based on our results, we advise against the semi-quantification of macrophages based on cell profile counting because it is unreliable and non-reproducible.

\section{Presence of enterovirus, adenovirus, parvovirus B19 and saffold virus in myocardial autopsy specimens - studies II + III}

In studies II and III, we applied PCR analyses on myocardial tissue specimens to improve the diagnostic contribution of the histopathological examinations performed in study I. The identification of an underlying viral etiology would be supportive of a myocarditis diagnosis suspected by histopathological evaluation. Study II was designed to examine the presence of enterovirus, adenovirus and PVB19 because these viruses are most commonly associated with myocarditis. Study III was designed to examine the presence of saffold virus to evaluate whether this recently discovered virus plays a role in human myocarditis. Overall, we aimed to determine the significance of these viruses as causes of myocarditis in forensic material.

In study II, we found that PVB19 was common in myocardial tissue samples from both myocarditis cases (29\%) and control hearts (44\%). Surprisingly, PVB19 was more frequently detected in the non-inflamed control group, which as suggested by many others ${ }^{13,31,35,36,42}$, supports the role of PVB19 as a latent virus with no or limited association with myocarditis.

To distinguish between acute and persistent infection, we performed serological analyses of PVB19-specific antibodies. In the project group, we only found two cases indicating possible acute infections. In the first case, we detected IgM antibodies but no IgG antibodies, indicating an acute 
infection ${ }^{46}$, although a cross-reactive non-specific antibody reaction cannot be excluded. In the second case, we did not detect PVB19-specific antibodies, but the lack of antibodies may indicate an acute infection in an early phase before antibodies become detectable because the myocardium was positive for PVB19 genomes (see Figure 1). However, a false positive PCR analysis is also possible. The lymphocyte profile counts in these two cases were $32 / \mathrm{mm}^{2}$ and $16 / \mathrm{mm}^{2}$, respectively. In the remaining cases, the detection of IgG indicated persistent PVB19 infections of the myocardium. In the control group, we did not detect PVB19-specific IgM in any of the cases. However, four cases were negative for both IgM and IgG antibodies despite a positive PVB19 PCR in the myocardium, which as in the project group, may be explained by a false positive PCR result or a very early acute PVB19 infection, before the antibodies and myocardial inflammation become detectable. In both project and control cases, a seroconversion from IgM to IgG just prior to death with an ongoing acute inflammation in the myocardium or a reactivation of a persistent PVB19 without IgM production cannot be excluded; as a consequence, some acute cases may have been misinterpreted as persistent infections ${ }^{37,46}$.

Our results indicate that a positive PVB19 PCR in cardiac autopsy specimens most likely represents a persistent infection with no or limited association with myocardial inflammation. Consequently, a positive PVB19 PCR result is not proof of a causal relationship between the presence of the virus and myocardial inflammation, and great caution should be shown when interpreting a positive PVB19 PCR result in the myocardium. Our results are in agreement with Pankuweit et al. and Bültmann et al, who showed that parvoviral sequences are located in the endothelium rather than cardiomyocytes; thus, PVB19 may be less cytopathogenic to myocytes ${ }^{75,76}$.

Unlike many others, we were unable to detect adenovirus and enterovirus in any of the tissue specimens in both the project and control groups. Both enterovirus and adenovirus are mainly associated with myocarditis in children and young adults, which may explain why the results are most likely influenced by the age distribution in our study groups, which ranged between $0-77$ years of age (12 and 1 cases $<12$ years of age in the project and control groups, respectively). The presence of adenovirus in myocardial autopsy specimens has also been studied by Kytö et al and Guarner et al, likewise with negative results ${ }^{12}, 14$. However, enterovirus has been detected in numerous previous studies, mainly from EMBs but also from autopsy samples with frequencies from $1.3-34 \%{ }^{26,28}$. Studies reporting the highest retrieval of enterovirus are mostly earlier 
studies of EMBs, and the methods for viral detection have undoubtedly been improved since then. Our results suggest that enterovirus and adenovirus are unusual causes of myocarditis-related deaths.

According to the viral shift theory, the prevalence of enterovirus and adenovirus as causes of myocarditis is decreasing, which is supported by our results. However, PVB19 is stated as an increasing cause of myocarditis, which contradicts our results. The viral shift may not only be caused by a shift in etiologies, but also to some extent by a shift in the etiologies searched for and the methods used. In the early studies aiming to identify an etiology of myocarditis, most attention was paid to enterovirus and adenovirus, and PVB19 was rarely examined. Later, PVB19 was increasingly associated with myocardial inflammation, and several studies detected PVB19 in myocardial tissue samples. As shown in Table 2, PVB19 is detected in most studies when PCR analysis for PVB19 is performed. PVB19 may have also been detected in the earlier studies if it was examined. The frequencies of PVB19 causing acute and persistent infection in the myocardium may not have changed significantly over the last decades; however, in the ongoing search for etiologies of myocarditis, the focus on PVB19 has increased, and the diagnostic methods for detecting the virus have improved. Rare as it may be, it is important to realize that PVB19 is capable of causing severe acute myocarditis with fatal outcome, as demonstrated both in this study and by others ${ }^{49}$. When evaluating PVB19 by PCR reaction on myocardial tissue, it is important to combine positive results with serology and/or in situ hybridization.

Saffold virus was only detected in 1 of 150 cases in study III. Like enteroviruses and adenoviruses, saffold virus also seems to primarily cause infections in children ${ }^{52,56,58,59}$. We detected saffold virus in three different anatomical compartments in our positive case (myocardium, blood and respiratory secretion), and to the best of our knowledge, this is the first demonstration of positive detection of saffold virus combined with histological inflammatory alterations in heart and lungs. The inflammatory changes in the myocardium were sparse and only suggestive of myocarditis when evaluated by the Dallas criteria (see article III for illustrations), but by quantification of lymphocytes as described in Study I, a result of $17 / \mathrm{mm}^{2}$ were reached. However, the result of the quantification should be interpreted with great caution. The detection of saffold virus as the only pathogen in the myocardium in combination with viremia supports the myocarditis diagnosis. The 
inflammatory changes in the lungs were more pronounced and consistent with an interstitial pneumonia. In both organs, the inflammatory changes were dominated by lymphocytes, indicating a viral etiology. In conjunction with prior studies, we may have contributed to the evidence that saffold virus is capable of causing invasive infections, including myocarditis, in humans. When possible limitations, such as the use of FFPE tissue for PCR and the age range of the study subjects are considered, we must also conclude that saffold virus only plays a minor etiologic role in human myocarditis.

The majority of myocarditis cases were negative for all the examined viruses, which is one of the key findings in studies II and III. Similar results have also been published by the European Study of Epidemiology and Treatment of Cardiac Inflammatory Diseases (ESETCID), where 93\% of a large cohort of patients $(n=526)$ with histological myocarditis was virus-negative ${ }^{28}$. PVB19 was not examined in the ESETCID study. This frequent finding of virus-negative cases can have several explanations. The inclusion criteria for the study subjects in the project group were an autopsy diagnosis of myocarditis regardless of whether it was acute, subacute or chronic. In the late stages, the virus may be cleared from the myocardium, but inflammatory changes may persist (see Figure 2). Consequently, some myocarditis cases in this study may have been caused by a viral infection, despite a negative PCR due to viral clearance before the PCR analysis. In the late stages, fibrosis is a dominating histological finding, and an assessment of the amount, distribution and localization of fibrosis can be helpful in the discrimination between acute and chronic stages of myocarditis, but this evaluation was not performed in this study. Another possible explanation is that the myocarditis is caused by the presence of viruses or other microorganisms that were not examined in this study. As illustrated in Table 2, numerous other viruses have been detected in the myocardium, but their frequencies are low compared with the viruses examined in this study, perhaps with the exception of cytomegalovirus and human herpesvirus-6. However, these viruses belong to the Herpesviridae, which also causes persistent infections like PVB19; consequently, the interpretation of a positive PCR result may generate similar difficulties ${ }^{120}$. Myocarditis caused by bacteria and protozoans is rare. As shown in Table 3, 9 of the project cases had verified sepsis prior to death, and in these cases, a bacterial etiology must be suspected.

Some of the virus negative myocarditis cases may be due to noninfectious causes, such as medical treatment, drug abuse or systemic diseases like autoimmune disorders or immunosuppressive 
conditions. In addition, other cardiac conditions, including hereditary diseases that sometimes present as SCD, are associated with myocardial inflammation. Although reportedly far less common than virus-induced myocarditis, these different causes may deserve additional awareness in forensic medicine. Special attention must be paid to drug abuse and medical treatment. Information regarding the health status of the deceased individual prior to death may provide important additional information that is supportive of a suspected myocarditis diagnosis. Cardiac and infectious symptoms commonly accompanying myocarditis were present in our study in $47 \%$ and $28 \%$, respectively. Unfortunately, our epidemiological data were very heterogeneous, with many unanswered questions, especially in the control group. These gaps made it impossible to examine the further diagnostic value of this information. This analysis was, however, performed by Casali et al., who compared clinical and histological features between lethal myocarditis $(n=26)$ and accidental inflammatory findings $(n=32)$ and found that the two groups differed significantly on several parameters, including anamnestic information (cardiac and flu-like anamnestic notes) and histological findings ${ }^{102}$. Their study indicates that epidemiological data may add important information that either supports or rejects a suspected myocarditis diagnosis.

\subsection{Study design considerations}

\section{The study groups}

\section{Project group}

The cases for this study were highly selected and consisted of deceased individuals who had been subjected to a forensic autopsy. As mentioned previously, the selection of cases for forensic autopsy in Denmark relies on police investigations and the Danish legislation regarding the referral of individuals for medico-legal external examination and forensic autopsy, and an autopsy is not performed in all myocarditis-related deaths. Consequently, our project group does not represent all myocarditis-related deaths in Denmark during the study period. 


\section{Control group}

In Denmark, a forensic autopsy is performed in $16 \%$ of all suicide cases ${ }^{121}$ and will typically be requested when the manner of death is uncertain or when death is caused by poisoning. We chose suicide cases for controls and excluded cases with known heart diseases because we wanted the control group to represent healthy myocardium and to confirm that cause of death was noncardiac. A major advantage in an autopsy study is the availability of tissue for examination, which includes tissue from healthy organs. We believe our selection of controls is superior to the previously reported studies, which included patients with other heart diseases as control subjects with possible impact on the histopathological findings. However, our selection of control subjects is also associated with disadvantages because many of the deceased either received medical treatment at the time of death or abused illicit drugs, which may have affected the results of study I.

\section{Material}

\section{Sampling of material}

In this study, we used autopsy material and applied a retrospective design, which has both several advantages and disadvantages. We utilized some of the great research potential found in a large amount of archival tissue samples, offering the opportunity to examine a large cohort of myocarditis cases. A similar study with a prospective study design would demand a long sampling period. However, because the tissue samples were sampled for the purpose of establishing the cause of death and not for this study, a varying number of specimens were available in each case. Tissue specimens from 4 standardized localizations were sampled in all cases according to the department's protocol, but in approximately $20 \%$ of the project cases, additionally specimens were available from either the circumference and/or the conductive system. We chose not to include these specimens, despite the loss of information, to standardize the material, allowing a direct comparison of the results between the two groups.

Cases included in the project group were selected by searching for the "myocarditis" diagnosis in an electronic database. A re-evaluation and re-classification of the diagnosis was performed to ensure a homogenous materiel. The re-evaluation was performed on new H\&E sections cut for the 
purpose of this study, and the disadvantage of this step was the risk of cutting through or cutting into inflammatory infiltrates, thus changing the original diagnosis and leading to an exclusion of cases from studies I and II. When examining the excluded cases, we found that this reversal happened in several cases, which illustrates some of the diagnostic challenges regarding sampling error that we face when diagnosing myocarditis histopathologically and highlights the fact that a non-inflamed histopathological finding does not necessarily rule out myocarditis.

Tissue degeneration may play an important role in a forensic material. The exact time span between death and autopsy varies to a great extent and is often a rough estimate. This variation may have influenced the histopathological examinations.

\section{$\underline{\text { PCR analysis and the limitations of FFPE tissue for virological analyses }}$}

In studies II and III, we used FFPE tissue specimens for virological examinations, which reduces the diagnostic sensitivity of the PCR analysis and may have resulted in some of the virus-negative results $^{122}$. In general, RNAs are more fragile than DNAs. However, many studies have shown that DNA and RNA from FFPE tissue are usable in molecular analyses, including pathogen detection, if only short amplicons are generated $(<200 \text { base pairs })^{123-126}$. This assumption was supported by the results of our quality control analysis, which showed that total nucleic extraction and amplification were possible for most samples.

Although PCR is recognized as a fast and sensitive method for the detection of viral genomes in the myocardium, it also has some disadvantages. The PCR technique cannot differentiate between infected cell types; consequently, a positive result might reflect an accidental amplification of viral genomes from infected blood cells rather than from infected myocytes. The viruses that primarily cause myocarditis are common and have a worldwide distribution. They frequently cause different infections other than myocarditis and may therefore be present in blood cells or other tissues without being associated with myocarditis. It is highly likely that some of the positive PVB19 PCR results are due to other infected cells, including endothelial cells, rather than cardiomyocytes. To avoid this contamination, the presence of the virus should be established inside the infected cells in the heart by other methods e.g., in situ hybridization. Unfortunately, this step was not possible in the present study. 


\section{Epidemiological data}

Premortem anamnestic notes including hospital records and police reports with a description of previous medical procedures and examinations, medical treatment, drug abuse, state of health at time of death and family history, may constitute important additional information that support a suspected myocarditis diagnosis. Unfortunately, we were unable to evaluate the diagnostic value of this information in the present study, because the available epidemiological data were very heterogeneous. Particularly in the control group, important information was often missing, especially with regard to medical health status prior to death. In Denmark, this information is collected by the police, and they are not interested in or educated to collect information that would be necessary for pattern recognition of diseases. Information is collected in a nonhomogeneous way, depending on the individual police officer, and negative and positive confirmed information are often left out. To collect of reliable information in the future, a crossdisciplinary collaboration is necessary.

\section{Method}

\section{Immunohistochemical staining}

A wide range of immunohistochemical reagents that stain $\mathrm{T}$ lymphocytes and macrophages are available (e.g., CD3, CD4, CD8, CD45 and CD68). CD3 and CD68 are used in our laboratory in daily practice; thus we are familiar with interpreting their results. Other immunohistochemical reagents could have been chosen. In addition to conventional immunohistochemical staining, some studies recommend the use of other pro-inflammatory markers such as MHC class I and II (major histocompatibility complex class I and II). Infiltration of the myocardium by immunocompetent cells is correlated with an up-regulation of MHC class I and II, which are expressed by antigenpresenting cells. The detection of up-regulated MHC class I and II may be used as a sign of inflammation in areas without cellular infiltration ${ }^{127}$. The diagnostic values of MHC class I and II in myocarditis and their usability on postmortem tissue need further examination, and they were not used in this study.

Because non-infectious causes of myocarditis, especially toxic causes due to the use/abuse of different kinds of drugs, may play an important role in forensic medicine, attention should also be given to the characterization and quantification of eosinophilic granulocytes in future studies. 


\section{Stereological quantification}

In study I, we chose to estimate the lymphocyte count per $\mathrm{mm}^{2}$ using a stereological semiquantitative method. The advantage of this method is a random selection of the analyzed areas of each section, which produces a less biased result compared with standard pathological examination ${ }^{112}$. Furthermore, by using detailed counting rules, we illustrated that our results were reproducible and thereby addressed some important limitations regarding previously reported studies on this subject. To reduce the biases further, sampling of the myocardial specimens should have been performed randomly (e.g., systematic uniform random sampling ${ }^{128}$. This step was not possible due to the retrospective design and is an obvious limitation of study I. In a future study, inter-observer variability could be estimated to evaluate the reproducibility of data between different researchers at other institutions.

A disadvantage of using a stereological cell profile counting method for the diagnosis of myocarditis is that it is time-consuming. Although an observer can be trained to evaluate the histological sections relatively rapidly, it will demand more working time than conventional histological examination. Because the heart often is subjected to histological analysis, implementation of a stereological procedure could have some impact on daily practice in forensic medicine. Furthermore, special equipment and software are required for fast analysis. 


\section{Conclusions}

In study I, we established histological quantitative criteria for the diagnosis of lymphocytic myocarditis in autopsy specimens by examining and comparing, to our knowledge, the largest cohorts of inflamed and non-inflamed myocardium to date by properly sampling of fields of view and a stereological cell profile counting method. We found that the highest combined sensitivity and specificity was obtained with a cut-of value on 13 lymphocytes per $\mathrm{mm}^{2}$ myocardium, corresponding to the latest proposed guidelines. In addition, we demonstrated that the majority of cases in both the project and the control groups presented with lymphocyte profile counts below 13 per $\mathrm{mm}^{2}$. Thus, we illustrated that a distinction between myocarditis and non-significant inflammatory changes solely based upon histological examination is extremely difficult, because the risk of creating a false negative or a false positive diagnosis is high. At low lymphocyte counts, quantitative diagnostic criteria fail to generate reliable evidence of myocarditis, even when based on stereological principles. Consequently, the implementation of quantitative criteria for the diagnosis of myocarditis in forensic medicine may be a valuable diagnostic tool at high lymphocyte profile counts, but at low lymphocyte profile counts, ancillary diagnostic tests are required. The implementation of quantitative criteria based on stereological methods with reproducible results can, however, allow the diagnosis to be performed uniformly, which will be a major advantage because it will enable us to perform more comparative studies in the future. Despite the use of large-sized tissue specimens for histological examination, we must conclude that sampling error has a major diagnostic impact. This impact constitutes a challenge for future recommendations on the diagnosis of myocarditis and is not easily solved. Furthermore, based on our results, we advise against including immunohistochemical (CD68) semi-quantification of macrophages based on cell profile counting in the quantitative criteria for the diagnosis of myocarditis.

In studies II and III, we applied virological analyses to enhance the diagnostic contribution of the histological examination. We found enterovirus, adenovirus, PVB19 and saffold virus to be rare causes of myocarditis-related deaths. PVB19 was frequently detected but most likely represented a persistent infection with no or limited association to myocardial inflammation. Consequently, great caution should be paid when interpreting a positive PVB19 PCR result in the myocardium. We suggest that supplementary diagnostic tests are undertaken to aid the interpretation of the 
PCR result. In this study, serological analyses were used. Overall, we applied virological analyses as an ancillary diagnostic tool to histological examination as the recent guidelines suggest and only succeeded in establishing an underlying etiology supportive of a myocarditis diagnosis in a few cases.

In the forensic investigation of myocarditis, a thorough examination with an emphasis on all possible causes is required. This examination includes an autopsy with the application of molecular diagnostic tests as recent guidelines propose. However, further investigations are often necessary to confirm the diagnosis. In forensic medicine, special attention must also be paid to non-viral causes of myocarditis because these causes are often present in forensic autopsy cases. All available premortem information, including medical charts and police records with a description of previous medical procedures and examinations, medical treatments, drug abuse, state of health at the time of death and family history, should be collected. This requirement calls for a multidisciplinary approach and is mandatory in the evaluation of myocardial inflammation. 


\section{Perspectives}

This study demonstrates that the diagnosis of myocarditis in a forensic setting is difficult and demands multidisciplinary cooperation between professionals with expert skills in cardiac diseases. This cooperation can be facilitated by the establishment of regional centers where clinicians, pathologists, forensic pathologists, microbiologists, immunologists, microbiologists and geneticists can combine their knowledge. To complete the molecular analyses, frozen blood, spleen and myocardial tissue specimens should be routinely collected at autopsy. Additional throat and rectal swabs are of value for detecting viruses because many cardiotropic viruses are found in much higher concentrations in these samples. A more systematic collection of information from relatives regarding history of the deceased individual should be performed to provide more homogenous epidemiological data. The implementation of a questionnaire for police officers or the collection of information by a trained person with skills in forensic medicine are better ways collect these data; a history sheet as described in the Guidelines on autopsy Practice could be used ${ }^{129}$. Genetic screening should be included in the molecular analyses when relevant and especially in cases of SCD, to aid in the differentiation of fatal myocarditis from nonsignificant myocardial inflammation and thereby establish a correct cause of death. Guidelines for autopsy investigation of SCD are available and should be incorporated ${ }^{96}$.

Future research studies should examine the diagnostic contribution of epidemiological information like Casali et al., preferably on larger populations. Furthermore, a prospective study similar to our study I should be conducted on myocardial autopsy specimens sampled systematical, uniform and random (SURS) to obtain an even more unbiased analysis of the amount of inflammatory cells in the normal myocardium. This knowledge will enable us to make more reliable evaluations of the possible contribution of different factors to myocardial inflammation. In particular, pharmaceuticals whose association to myocarditis are only sparsely reported and need further documentation may add valuable information to the evaluation of myocardial inflammation in forensic medicine. 


\section{English summary}

Myocarditis constitutes a very important unsolved challenge in the practice of cardiovascular medicine and is a major cause of chronic heart failure and sudden unexpected death in infants and young adults. It can result from a wide spectrum of causes with viral infection reported as the most common. The clinical presentation is highly variable which makes the diagnosis difficult. Histopathological examination in combination with virological analyses is recommended in the latest guidelines for a definite diagnosis. Despite this, the diagnosis of myocarditis continues to prompt considerable debate.

Quantitative diagnostic criteria for myocarditis - study I: We aimed to establish quantitative diagnostic criteria for lymphocytic myocarditis in autopsy samples by using a stereological cell profile counting method. We quantified and compared the presence of lymphocytes and macrophages in myocardial autopsy specimens from 112 deceased individuals with myocarditis and 86 control subjects with non-inflamed hearts. We found the mean number to be 52.7 lymphocyte profiles $/ \mathrm{mm}^{2}$ (range 3.7 - 946; standard deviation 131) in the myocarditis group and 9.7 (range 2.1 - 25.9; standard deviation 4.6) in the control group. By examination of the intraobserver variability we demonstrated that our results were highly reproducible. The cut-off value for the diagnosis of myocarditis was determined by calculating sensitivity plus specificity, which reached the highest combination at 13 lymphocyte profiles $/ \mathrm{mm}^{2}$ (sensitivity $68 \%$; specificity $83 \%$ ). A considerable proportion of subjects in both the myocarditis and the control group had lymphocyte profile counts below $30 / \mathrm{mm}^{2}$, representing a diagnostic challenge due to the increased risk of creating false negative or false positive results. We found the quantification of macrophages impossible based on cell profile counting.

\section{Presence of enterovirus, adenovirus, parvovirus B19 and saffold virus in myocardial autopsy} specimens with myocarditis - study II + III: We aimed to determine the significance of enterovirus, adenovirus, parvovirus B19 (PVB19) and saffold virus as causes of myocarditis in a forensic material. We applied polymerase chain reaction to the myocardial tissue specimens examined in study I in order to enhance the diagnostic contribution of the histopathological examinations. The distinction between acute and persistent PVB19 infection was made the by serological 
determination of PVB19-specific immunoglobulins M and G. We found PVB19 in 29\% of the myocarditis cases and in $44 \%$ of the control cases. Serological evidence of an acute PVB infection, determined by the presence of immunoglobulin $\mathrm{M}$, was only present in one case. Saffold virus was detected in one of the myocarditis cases, while all the tissue samples were negative for the presence of enterovirus and adenovirus.

In conclusion: At high lymphocyte counts quantitative diagnostic criteria based on stereological principles generates reliable and reproducible results, but at low lymphocyte counts the risk of creating a false negative or a false positive diagnosis is high and ancillary diagnostic tests should be performed to support a suspected myocarditis diagnosis. By adding virological examinations we found enterovirus, adenovirus, PVB19 and saffold virus to be rare causes of myocarditis-related deaths. PVB19 was frequently detected, but most likely represented a persistent infection with no or limited association to myocardial inflammation. Consequently, great caution should be paid when interpreting a positive PVB19 PCR result in the myocardium.

The forensic investigation of myocardial inflammation demands a thorough examination, including special attention to non-viral causes. All available pre-mortem information including medical charts and police records with a description of previous medical procedures and examinations, medical treatments, drug abuse, state of health at the time of death and family history should be collected. This calls for a multidisciplinary approach and is mandatory in the evaluation of myocardial inflammation. 


\section{Dansk resumé}

Myocarditis er en væsentlig årsag til alvorlig hjertesygdom og pludselig $d \emptyset d$ især hos yngre personer. Årsagerne til myocarditis er mange, men virusinfektion er rapporteret som den hyppigste. Den kliniske præsentation varierer og er overvejende ukarakteristisk, hvilket gør det vanskeligt at stille diagnosen. De seneste guidelines anbefaler histologisk undersøgelse af myocardiet kombineret med virologiske analyser som den bedste måde til at opnå en sikker diagnose. Diagnostik af myocarditis er dog fortsat en udfordring og de diagnostiske tiltag bliver løbende debatteret.

Kvantitative diagnostiske kriterier for myocarditis - Studie I: Vores formål var at etablere kvantitative diagnostiske kriterier for lymfatisk myocarditis $\mathrm{i}$ et retsmedicinsk materiale. Ved anvendelse af en stereologisk tællemetode estimerede vi forekomsten af lymfocytter og makrofager i vævsprøver fra myocardiet fra 112 afdøde individer med myocarditis og 86 afd $\varnothing$ de individer uden myocarditis (kontrolgruppe). Resultaterne $\mathrm{i}$ de to grupper blev sammenlignet. Vi fandt i gennemsnit 52,7 lymfocytprofiler/ $\mathrm{mm}^{2}$ myocardium (3,7 - 946; standardafvigelse 131) i myocarditisgruppen og 9,7 lymfocytprofiler/mm $\mathrm{mm}^{2}$ myocardium $(2,1-25,9$; standardafvigelse 4,6) i kontrolgruppen. Ved undersøgelse af intra-observer variationen viste vi, at vores resultater var reproducerbare. Cut-off værdien til diagnosticering af myocarditis blev bestemt ved at beregne sensitivitet og specificitet, som nåede den højeste kombination ved 13 lymfocytprofiler/mm ${ }^{2}$ myocardium (sensitivitet 68\%, specificitet 83\%). I en betydelig del af de afdøde individer i både myocarditis- og kontrolgruppen var antallet af lymfocytprofiler under $30 / \mathrm{mm}^{2}$, og i disse tilfælde var risikoen for en falsk positiv eller falsk negativ myocarditis diagnose $h \emptyset j$.

Vi fandt at en kvantitering af makrofager baseret på celleprofil-tælling var upålidelig.

Forekomsten af enterovirus, adenovirus, parvovirus B19 og saffold virus i myokardievæv fra afdøde med myocarditis - Studie II og III: Ved anvendelse af Polymerase Chain Reaction unders $\varnothing$ gte vi forekomsten af enterovirus, adenovirus, parvovirus B19 (PVB19) og saffold virus i vævsprøverne fra myocardiet fra studie I, med det formål at belyse deres betydning som ætiologier til myocarditis i et retsmedicinsk materiale. Differentiering mellem akut og latent PVB19 
infektion blev foretaget på baggrund af serologiske undersøgelser med målinger af PVB19 specifikke immunglobuliner IgM og IgG. Vi fandt PVB19 i 29\% i myocarditisgruppen og 44\% i kontrolgruppen. Serologisk indikation på en akut PVB19 infektion bestemt ved tilstedeværelsen af IgM var til stede i ét tilfælde i myocarditisgruppen. Saffold virus blev påvist i ét tilfælde, mens enterovirus og adenovirus ikke blev påvist i nogen af prøverne.

Konklusion: Ved høje lymfocyttal kan kvantitative kriterier til diagnostik af myocarditis generere pålidelige og reproducerbare resultater, men ved lave lymfocyttal er risikoen for en falsk negativ eller falsk positiv diagnose $h \varnothing j$, hvorfor yderligere unders $\varnothing$ gelser bør foretages med henblik på at be- eller afkræfte mistanken om myocarditis. Ved de virologiske undersøgelser fandt vi, at enterovirus, adenovirus, PVB19 og saffold virus var sjældne årsager til myocarditis-relaterede dødsfald. PVB19 blev hyppigt detekteret i både myocarditis- og kontrolgruppen, men de serologiske undersøgelser indikerede at fundet oftest repræsenterede en latent infektion med begrænset eller ingen betydning for de inflammatoriske forandringer i myocardiet. På den baggrund bør stor forsigtighed udvises ved fortolkning af et positivt PVB19 resultat i myocardiet.

Den retsmedicinske evaluering af inflammatoriske forandringer i myocardiet kræver en gennemgående undersøgelse med særlig vægt på de non-virale ætiologier. Alle tilgængelige oplysninger om afdøde, herunder journalnotater, politiets efterforskningsrapporter med en beskrivelse af afdødes tidligere helbredsstatus, helbredstilstand op til dødsfaldet, medicinsk behandling, stofmisbrug samt familiær disposition bør indsamles. Dette kræver et tværfagligt samarbejde, og er obligatorisk for en tilfredsstillende evaluering af inflammatoriske forandringer i myocardiet. 


\section{References}

(1) Retsinformation. https://www.retsinformation.dk/forms/r0710.aspx?id=130455\#K56 (in Danish) . 2010.

Ref Type: Online Source

(2) Retsinformation. https://www.retsinformation.dk/forms/r0710.aspx?id=130455 (in Danish) . 2010. Ref Type: Online Source

(3) Rapport fra arbejdsgruppen om dødsfald, der anmeldes til politiet. http://www.politi.dk/NR/rdonlyres/57C0A4A9-4B94-4197-8177D321107B6206/0/EndeligRapport_Arbejdsgruppenomdoedsfald.pdf . 2012.

Ref Type: Online Source

(4) Doolan A, Langlois N, Semsarian C. Causes of sudden cardiac death in young Australians. Med J Aust 2004 February 2;180(3):110-2.

(5) Diaz FJ, Loewe C, Jackson A. Death caused by myocarditis in Wayne County, Michigan: a 9-year retrospective study. Am J Forensic Med Pathol 2006 December;27(4):300-3.

(6) Langlois NE. Sudden adult death. Forensic Sci Med Pathol 2009;5(3):210-32.

(7) D'Ambrosio A, Patti G, Manzoli A et al. The fate of acute myocarditis between spontaneous improvement and evolution to dilated cardiomyopathy: a review. Heart 2001 May;85(5):499-504.

(8) Basso C, Calabrese F, Angelini A, Carturan E, Thiene G. Classification and histological, immunohistochemical, and molecular diagnosis of inflammatory myocardial disease. Heart Fail Rev 2012 October 25.

(9) Caforio AL, Pankuweit S, Arbustini E et al. Current state of knowledge on aetiology, diagnosis, management, and therapy of myocarditis: a position statement of the European Society of Cardiology Working Group on Myocardial and Pericardial Diseases. Eur Heart J 2013 July 3.

(10) Kindermann I, Barth C, Mahfoud F et al. Update on myocarditis. J Am Coll Cardiol 2012 February 28;59(9):779-92.

(11) Maisch B, Noutsias M, Ruppert V, Richter A, Pankuweit S. Cardiomyopathies: classification, diagnosis, and treatment. Heart Fail Clin 2012 January;8(1):53-78.

(12) Guarner J, Bhatnagar J, Shieh WJ et al. Histopathologic, immunohistochemical, and polymerase chain reaction assays in the study of cases with fatal sporadic myocarditis. Hum Pathol 2007 September;38(9):1412-9.

(13) Koepsell SA, Anderson DR, Radio SJ. Parvovirus B19 is a bystander in adult myocarditis. Cardiovasc Pathol 2012 November;21(6):476-81.

(14) Kyto V, Vuorinen T, Saukko P et al. Cytomegalovirus infection of the heart is common in patients with fatal myocarditis. Clin Infect Dis 2005 March 1;40(5):683-8. 
(15) Richardson P, McKenna W, Bristow M et al. Report of the 1995 World Health Organization/International Society and Federation of Cardiology Task Force on the Definition and Classification of cardiomyopathies. Circulation 1996 March 1;93(5):841-2.

(16) Nippoldt TB, Edwards WD, Holmes DR, Jr., Reeder GS, Hartzler GO, Smith HC. Right Ventricular endomyocardial biopsy: clinicopathologic correlates in 100 consecutive patients. Mayo Clin Proc 1982 July;57(7):407-18.

(17) Mason JW. Basic research on myocarditis: superb but unrequited. J Am Coll Cardiol 2013 November 5;62(19):1746-7.

(18) Fenoglio JJ, Jr., Ursell PC, Kellogg CF, Drusin RE, Weiss MB. Diagnosis and classification of myocarditis by endomyocardial biopsy. N Eng/ J Med 1983 January 6;308(1):12-8.

(19) Mattingly TW. CHANGING CONCEPTS OF MYOCARDIAL DISEASES. JAMA 1965 January 4;191:33-7.

(20) Sakakibara S, Konno S. Endomyocardial biopsy. Jpn Heart J 1962 November;3:537-43.

(21) Passarino G, Burlo P, Ciccone G et al. Prevalence of myocarditis at autopsy in Turin, Italy. Arch Pathol Lab Med 1997 June;121(6):619-22.

(22) Burlo P, Comino A, Di G, V, Passarino G, Mollo F. [Adult myocarditis in a general hospital: observations on 605 autopsies]. Pathologica 1995 December;87(6):646-9.

(23) Subirana MT, Juan-Babot JO, Puig T et al. Specific characteristics of sudden death in a mediterranean Spanish population. Am J Cardiol 2011 February 15;107(4):622-7.

(24) Kyto V, Saukko P, Lignitz E et al. Diagnosis and presentation of fatal myocarditis. Hum Pathol 2005 September;36(9):1003-7.

(25) Jin O, Sole MJ, Butany JW et al. Detection of enterovirus RNA in myocardial biopsies from patients with myocarditis and cardiomyopathy using gene amplification by polymerase chain reaction. Circulation 1990 July;82(1):8-16.

(26) Why HJ, Meany BT, Richardson PJ et al. Clinical and prognostic significance of detection of enteroviral RNA in the myocardium of patients with myocarditis or dilated cardiomyopathy. Circulation 1994 June;89(6):2582-9.

(27) Martin AB, Webber S, Fricker FJ et al. Acute myocarditis. Rapid diagnosis by PCR in children. Circulation 1994 July;90(1):330-9.

(28) Hufnagel G, Pankuweit S, Richter A, Schonian U, Maisch B. The European Study of Epidemiology and Treatment of Cardiac Inflammatory Diseases (ESETCID). First epidemiological results. Herz 2000 May;25(3):279-85.

(29) Bowles NE, Ni J, Kearney DL et al. Detection of viruses in myocardial tissues by polymerase chain reaction. evidence of adenovirus as a common cause of myocarditis in children and adults. J Am Coll Cardiol 2003 August 6;42(3):466-72. 
(30) Pankuweit S, Portig I, Eckhardt H, Crombach M, Hufnagel G, Maisch B. Prevalence of viral genome in endomyocardial biopsies from patients with inflammatory heart muscle disease. Herz 2000 May;25(3):221-6.

(31) Donoso MO, Meyer R, Prosch S et al. High prevalence of cardiotropic viruses in myocardial tissue from explanted hearts of heart transplant recipients and heart donors: a 3-year retrospective study from a German patients' pool. J Heart Lung Transplant 2005 October;24(10):1632-8.

(32) Kuhl U, Pauschinger $M$, Noutsias $M$ et al. High prevalence of viral genomes and multiple viral infections in the myocardium of adults with "idiopathic" left ventricular dysfunction. Circulation 2005 February 22;111(7):887-93.

(33) Mahrholdt $\mathrm{H}$, Wagner A, Deluigi CC et al. Presentation, patterns of myocardial damage, and clinical course of viral myocarditis. Circulation 2006 October 10;114(15):1581-90.

(34) Kindermann I, Kindermann $M$, Kandolf $R$ et al. Predictors of outcome in patients with suspected myocarditis. Circulation 2008 August 5;118(6):639-48.

(35) Schenk T, Enders M, Pollak S, Hahn R, Huzly D. High prevalence of human parvovirus B19 DNA in myocardial autopsy samples from subjects without myocarditis or dilative cardiomyopathy. $J$ Clin Microbiol 2009 January;47(1):106-10.

(36) Kuethe F, Lindner J, Matschke K et al. Prevalence of parvovirus B19 and human bocavirus DNA in the heart of patients with no evidence of dilated cardiomyopathy or myocarditis. Clin Infect Dis 2009 December 1;49(11):1660-6.

(37) Mahfoud F, Gartner B, Kindermann M et al. Virus serology in patients with suspected myocarditis: utility or futility? Eur Heart J 2011 April;32(7):897-903.

(38) Gaaloul I, Riabi S, Harrath R et al. Sudden unexpected death related to enterovirus myocarditis: histopathology, immunohistochemistry and molecular pathology diagnosis at post-mortem. $B M C$ Infect Dis 2012;12:212.

(39) Moore Melinda. Enteroviral Disease in the Unites Sates, 1970-1979. The Journal of Infectious Diseases 2014;146(1):103-8.

(40) Ooi MH, Wong SC, Lewthwaite P, Cardosa MJ, Solomon T. Clinical features, diagnosis, and management of enterovirus 71. Lancet Neurol 2010 November;9(11):1097-105.

(41) Fox JP, Hall CE, Cooney MK. The Seattle Virus Watch. VII. Observations of adenovirus infections. Am J Epidemiol 1977 April;105(4):362-86.

(42) Wang X, Zhang G, Liu F, Han M, Xu D, Zang Y. Prevalence of human parvovirus B19 DNA in cardiac tissues of patients with congenital heart diseases indicated by nested PCR and in situ hybridization. J Clin Virol 2004 September;31(1):20-4.

(43) Soderlund-Venermo M, Hokynar K, Nieminen J, Rautakorpi H, Hedman K. Persistence of human parvovirus B19 in human tissues. Pathol Biol (Paris) 2002 June;50(5):307-16.

(44) Cassinotti P, Burtonboy G, Fopp M, Siegl G. Evidence for persistence of human parvovirus B19 DNA in bone marrow. J Med Virol 1997 November;53(3):229-32. 
(45) Soderlund M, von ER, Haapasaari J, Kiistala U, Kiviluoto O, Hedman K. Persistence of parvovirus B19 DNA in synovial membranes of young patients with and without chronic arthropathy. Lancet 1997 April 12;349(9058):1063-5.

(46) Modrow S, Dorsch S. Antibody responses in parvovirus B19 infected patients. Pathol Biol (Paris) 2002 June;50(5):326-31.

(47) Heegaard ED, Brown KE. Human parvovirus B19. Clin Microbiol Rev 2002 July;15(3):485-505.

(48) Cohen BJ, Buckley MM. The prevalence of antibody to human parvovirus B19 in England and Wales. J Med Microbiol 1988 February;25(2):151-3.

(49) Lamparter S, Schoppet M, Pankuweit S, Maisch B. Acute parvovirus B19 infection associated with myocarditis in an immunocompetent adult. Hum Pathol 2003 July;34(7):725-8.

(50) Jones MS, Lukashov VV, Ganac RD, Schnurr DP. Discovery of a novel human picornavirus in a stool sample from a pediatric patient presenting with fever of unknown origin. J Clin Microbiol 2007 July;45(7):2144-50.

(51) Blinkova O, Rosario K, Li L et al. Frequent detection of highly diverse variants of cardiovirus, cosavirus, bocavirus, and circovirus in sewage samples collected in the United States. J Clin Microbiol 2009 November;47(11):3507-13.

(52) Blinkova O, Kapoor A, Victoria J et al. Cardioviruses are genetically diverse and cause common enteric infections in South Asian children. J Virol 2009 May;83(9):4631-41.

(53) Reddacliff LA, Kirkland PD, Hartley WJ, Reece RL. Encephalomyocarditis virus infections in an Australian zoo. J Zoo Wildl Med 1997 June;28(2):153-7.

(54) Grobler DG, Raath JP, Braack LE et al. An outbreak of encephalomyocarditis-virus infection in freeranging African elephants in the Kruger National Park. Onderstepoort J Vet Res 1995 June;62(2):97108.

(55) Chiu CY, Greninger AL, Kanada K et al. Identification of cardioviruses related to Theiler's murine encephalomyelitis virus in human infections. Proc Natl Acad Sci U S A 2008 September 16;105(37):14124-9.

(56) Abed Y, Boivin G. New Saffold cardioviruses in 3 children, Canada. Emerg Infect Dis 2008 May;14(5):834-6.

(57) Drexler JF, Luna LK, Stocker A et al. Circulation of 3 lineages of a novel Saffold cardiovirus in humans. Emerg Infect Dis 2008 September;14(9):1398-405.

(58) Nielsen AC, Bottiger B, Banner J, Hoffmann T, Nielsen LP. Serious invasive Saffold virus infections in children, 2009. Emerg Infect Dis 2012 January;18(1):7-12.

(59) Drexler JF, Baumgarte S, Eschbach-Bludau M et al. Human cardioviruses, meningitis, and sudden infant death syndrome in children. Emerg Infect Dis 2011 December;17(12):2313-5.

(60) Peter J.Krause, Linda K.Bockenstedt. Lyme Disease and the Heart. Circulation 2014;127:e451-e454. 
(61) Feldman AM, McNamara D. Myocarditis. N Eng/ J Med 2000 November 9;343(19):1388-98.

(62) Burke AP, Saenger J, Mullick F, Virmani R. Hypersensitivity myocarditis. Arch Pathol Lab Med 1991 August;115(8):764-9.

(63) De BD, Serroni N, Campanella D et al. Update on the adverse effects of clozapine: focus on myocarditis. Curr Drug Saf 2012 February;7(1):55-62.

(64) Phillips K, Luk A, Soor GS, Abraham JR, Leong S, Butany J. Cocaine cardiotoxicity: a review of the pathophysiology, pathology, and treatment options. Am J Cardiovasc Drugs 2009;9(3):177-96.

(65) Pilgrim JL, Woodford N, Drummer OH. Cocaine in sudden and unexpected death: a review of 49 post-mortem cases. Forensic Sci Int 2013 April 10;227(1-3):52-9.

(66) Lucena J, Blanco $M$, Jurado $C$ et al. Cocaine-related sudden death: a prospective investigation in south-west Spain. Eur Heart J 2010 February;31(3):318-29.

(67) Zhang M, Tavora F, Zhang $\mathrm{Y}$ et al. The role of focal myocardial inflammation in sudden unexpected cardiac and noncardiac deaths--a clinicopathological study. Int J Legal Med 2013 January;127(1):131-8.

(68) Courand PY, Croisille P, Khouatra C, Cottin V, Kirkorian G, Bonnefoy E. Churg-Strauss syndrome presenting with acute myocarditis and cardiogenic shock. Heart Lung Circ 2012 March;21(3):17881.

(69) Nicklin A, Byard RW. Lethal manifestations of systemic lupus erythematosus in a forensic context. J Forensic Sci 2011 March;56(2):423-8.

(70) Yajima T, Knowlton KU. Viral myocarditis: from the perspective of the virus. Circulation 2009 May 19;119(19):2615-24.

(71) Andreoletti L, Leveque N, Boulagnon C, Brasselet C, Fornes P. Viral causes of human myocarditis. Arch Cardiovasc Dis 2009 June;102(6-7):559-68.

(72) Kuhl U, Schultheiss HP. Myocarditis in children. Heart Fail Clin 2010 October;6(4):483-ix.

(73) Blauwet LA, Cooper LT. Myocarditis. Prog Cardiovasc Dis 2010 January;52(4):274-88.

(74) Kawai C, Matsumori A. Dilated cardiomyopathy update: infectious-immune theory revisited. Heart Fail Rev 2013 November;18(6):703-14.

(75) Bultmann BD, Klingel K, Sotlar K et al. Fatal parvovirus B19-associated myocarditis clinically mimicking ischemic heart disease: an endothelial cell-mediated disease. Hum Pathol 2003 January;34(1):92-5.

(76) Pankuweit S, Klingel K. Viral myocarditis: from experimental models to molecular diagnosis in patients. Heart Fail Rev 2013 November;18(6):683-702.

(77) Priori SG, Aliot E, Blomstrom-Lundqvist C et al. Task Force on Sudden Cardiac Death, European Society of Cardiology. Europace 2002 January;4(1):3-18. 
(78) Maron BJ, Doerer JJ, Haas TS, Tierney DM, Mueller FO. Sudden deaths in young competitive athletes: analysis of 1866 deaths in the United States, 1980-2006. Circulation 2009 March 3;119(8):1085-92.

(79) Drory $Y$, Turetz $Y$, Hiss $Y$ et al. Sudden unexpected death in persons less than 40 years of age. Am J Cardiol 1991 November 15;68(13):1388-92.

(80) Liberthson RR. Sudden death from cardiac causes in children and young adults. N Eng/ J Med 1996 April 18;334(16):1039-44.

(81) Mason JW, O'Connell JB, Herskowitz A et al. A clinical trial of immunosuppressive therapy for myocarditis. The Myocarditis Treatment Trial Investigators. N Engl J Med 1995 August 3;333(5):26975.

(82) Pinamonti B, Alberti E, Cigalotto A et al. Echocardiographic findings in myocarditis. Am J Cardiol 1988 August 1;62(4):285-91.

(83) Friedrich MG, Strohm O, Schulz-Menger J, Marciniak H, Luft FC, Dietz R. Contrast media-enhanced magnetic resonance imaging visualizes myocardial changes in the course of viral myocarditis. Circulation 1998 May 12;97(18):1802-9.

(84) Lauer B, Niederau C, Kuhl U et al. Cardiac troponin T in patients with clinically suspected myocarditis. J Am Coll Cardiol 1997 November 1;30(5):1354-9.

(85) Smith SC, Ladenson JH, Mason JW, Jaffe AS. Elevations of cardiac troponin I associated with myocarditis. Experimental and clinical correlates. Circulation 1997 January 7;95(1):163-8.

(86) Morgera T, Di LA, Dreas L et al. Electrocardiography of myocarditis revisited: clinical and prognostic significance of electrocardiographic changes. Am Heart J 1992 August;124(2):455-67.

(87) Abdel-Aty H, Boye $\mathrm{P}$, Zagrosek $\mathrm{A}$ et al. Diagnostic performance of cardiovascular magnetic resonance in patients with suspected acute myocarditis: comparison of different approaches. J Am Coll Cardiol 2005 June 7;45(11):1815-22.

(88) Chu GC, Flewitt JA, Mikami Y, Vermes E, Friedrich MG. Assessment of acute myocarditis by cardiovascular MR: diagnostic performance of shortened protocols. Int J Cardiovasc Imaging 2013 February 13.

(89) Carniel E, Sinagra G, Bussani R et al. Fatal myocarditis: morphologic and clinical features. Ital Heart J 2004 September;5(9):702-6.

(90) Baandrup U, Olsen EG. Critical analysis of endomyocardial biopsies from patients suspected of having cardiomyopathy. I: Morphological and morphometric aspects. Br Heart J 1981 May;45(5):475-86.

(91) Chow LH, Radio SJ, Sears TD, McManus BM. Insensitivity of right ventricular endomyocardial biopsy in the diagnosis of myocarditis. J Am Coll Cardiol 1989 October;14(4):915-20.

(92) Hauck AJ, Kearney DL, Edwards WD. Evaluation of postmortem endomyocardial biopsy specimens from 38 patients with lymphocytic myocarditis: implications for role of sampling error. Mayo Clin Proc 1989 October;64(10):1235-45. 
(93) Burke AP, Farb A, Robinowitz M, Virmani R. Serial sectioning and multiple level examination of endomyocardial biopsies for the diagnosis of myocarditis. Mod Pathol 1991 November;4(6):690-3.

(94) Frustaci A, Bellocci F, Olsen EG. Results of biventricular endomyocardial biopsy in survivors of cardiac arrest with apparently normal hearts. Am J Cardiol 1994 November 1;74(9):890-5.

(95) Narula N, McNamara DM. Endomyocardial biopsy and natural history of myocarditis. Heart Fail Clin 2005 October;1(3):391-406.

(96) Oliva A, Brugada R, D'Aloja E et al. State of the art in forensic investigation of sudden cardiac death. Am J Forensic Med Pathol 2011 March;32(1):1-16.

(97) Aretz HT. Myocarditis: the Dallas criteria. Hum Pathol 1987 June;18(6):619-24.

(98) Shanes JG, Ghali J, Billingham ME et al. Interobserver variability in the pathologic interpretation of endomyocardial biopsy results. Circulation 1987 February;75(2):401-5.

(99) Baughman KL. Diagnosis of myocarditis: death of Dallas criteria. Circulation 2006 January 31;113(4):593-5.

(100) Kolbeck PC, Steenbergen C, Wolfe JA, Sanfilippo F, Jennings RB. The correlation of mononuclear cell phenotype in endomyocardial biopsies with clinical history and cardiac dysfunction. Am J Clin Pathol 1989 January;91(1):37-44.

(101) Milei J, Bortman G, Fernandez-Alonso G, Grancelli H, Beigelman R. Immunohistochemical staining of lymphocytes for the reliable diagnosis of myocarditis in endomyocardial biopsies. Cardiology 1990;77(2):77-85.

(102) Casali MB, Lazzaro A, Gentile G, Blandino A, Ronchi E, Zoja R. Forensic grading of myocarditis: an experimental contribution to the distinction between lethal myocarditis and incidental myocarditis. Forensic Sci Int 2012 November 30;223(1-3):78-86.

(103) Kitulwatte ID, Kim PJ, Pollanen MS. Sudden death related myocarditis: a study of 56 cases. Forensic Sci Med Pathol 2010 March;6(1):13-9.

(104) Edwards WD, Holmes DR, Jr., Reeder GS. Diagnosis of active lymphocytic myocarditis by endomyocardial biopsy: quantitative criteria for light microscopy. Mayo Clin Proc 1982 July;57(7):419-25.

(105) Kuhl U, Seeberg B, Schultheiss HP, Strauer BE. Immunohistological characterization of infiltrating lymphocytes in biopsies of patients with clinically suspected dilated cardiomyopathy. Eur Heart J 1994 August;15 Suppl C:62-7.

(106) Maisch B, Portig I, Ristic A, Hufnagel G, Pankuweit S. Definition of inflammatory cardiomyopathy (myocarditis): on the way to consensus. A status report. Herz 2000 May;25(3):200-9.

(107) Feeley KM, Harris J, Suvarna SK. Necropsy diagnosis of myocarditis: a retrospective study using CD45RO immunohistochemistry. J Clin Pathol 2000 February;53(2):147-9. 
(108) Krous HF, Ferandos C, Masoumi H et al. Myocardial inflammation, cellular death, and viral detection in sudden infant death caused by SIDS, suffocation, or myocarditis. Pediatr Res 2009 July;66(1):17-21.

(109) Linder J, Cassling RS, Rogler WC et al. Immunohistochemical characterization of lymphocytes in uninflamed ventricular myocardium. Implications for myocarditis. Arch Pathol Lab Med 1985 October;109(10):917-20.

(110) Mues B, Brisse B, Zwadlo G, Themann H, Bender F, Sorg C. Phenotyping of macrophages with monoclonal antibodies in endomyocardial biopsies as a new approach to diagnosis of myocarditis. Eur Heart J 1990 July;11(7):619-27.

(111) Dettmeyer R, Baasner A, Schlamann M et al. Role of virus-induced myocardial affections in sudden infant death syndrome: a prospective postmortem study. Pediatr Res 2004 June;55(6):947-52.

(112) Mayhew TM, Gundersen HJ. If you assume, you can make an ass out of $u$ and me': a decade of the disector for stereological counting of particles in 3D space. J Anat 1996 February;188 ( Pt 1):1-15.

(113) Gundersen HJ, Bagger P, Bendtsen TF et al. The new stereological tools: disector, fractionator, nucleator and point sampled intercepts and their use in pathological research and diagnosis. APMIS 1988 October;96(10):857-81.

(114) Nedergaard BS, Nielsen K, Nyengaard JR, Ladekarl M. Stereologic estimation of the total numbers, the composition and the anatomic distribution of lymphocytes in cone biopsies from patients with stage I squamous cell carcinoma of the cervix uteri. APMIS 2007 December;115(12):1321-30.

(115) Gundersen HJ, Bendtsen TF, Korbo L et al. Some new, simple and efficient stereological methods and their use in pathological research and diagnosis. APMIS 1988 May;96(5):379-94.

(116) Loewe, R. RNA-Isolation aus FFPE-Gewebe: Säulchen- und Bead-basierte Methoden . Laborwelt 12[05], 38-39. 2011. Germany.

Ref Type: Magazine Article

(117) Parvovirus B19 Immunoassay. 2014.

Ref Type: Online Source

(118) Bland JM, Altman DG. Statistical methods for assessing agreement between two methods of clinical measurement. Lancet 1986 February 8;1(8476):307-10.

(119) Landis JR, Koch GG. The measurement of observer agreement for categorical data. Biometrics 1977 March;33(1):159-74.

(120) Hubacek P, Virgili A, Ward KN et al. HHV-6 DNA throughout the tissues of two stem cell transplant patients with chromosomally integrated HHV-6 and fatal CMV pneumonitis. Br J Haematol 2009 May;145(3):394-8.

(121) Larsen ST, Lynnerup N. Medico-legal autopsies in Denmark. Dan Med Bull 2011 March;58(3):A4247.

(122) Carturan E, Tester DJ, Brost BC, Basso C, Thiene G, Ackerman MJ. Postmortem genetic testing for conventional autopsy-negative sudden unexplained death: an evaluation of different DNA 
extraction protocols and the feasibility of mutational analysis from archival paraffin-embedded heart tissue. Am J Clin Pathol 2008 March;129(3):391-7.

(123) Ben-Ezra J, Johnson DA, Rossi J, Cook N, Wu A. Effect of fixation on the amplification of nucleic acids from paraffin-embedded material by the polymerase chain reaction. $J$ Histochem Cytochem 1991 March;39(3):351-4.

(124) Mizuno T, Nagamura $\mathrm{H}$, Iwamoto KS et al. RNA from decades-old archival tissue blocks for retrospective studies. Diagn Mol Pathol 1998 August;7(4):202-8.

(125) Sharma M, Mishra B, Vandana et al. Ribonucleic acid extraction from archival formalin fixed paraffin embedded myocardial tissues for gene expression and pathogen detection. J Clin Lab Anal 2012 July;26(4):279-85.

(126) Farragher SM, Tanney A, Kennedy RD, Paul HD. RNA expression analysis from formalin fixed paraffin embedded tissues. Histochem Cell Biol 2008 September;130(3):435-45.

(127) Kuhl U, Noutsias M, Schultheiss HP. Immunohistochemistry in dilated cardiomyopathy. Eur Heart J 1995 December;16 Suppl 0:100-6.

(128) Boyce RW, Dorph-Petersen KA, Lyck L, Gundersen HJ. Design-based stereology: introduction to basic concepts and practical approaches for estimation of cell number. Toxicol Pathol 2010 December;38(7):1011-25.

(129) TRAGADY Trans-Tasman Response Against sudden Death in the Young. Post-mortem in sudden unexpected death in the young: Guidelines on autopsy practice. 2008.

Ref Type: Online Source

(130) Heim A, Ebnet C, Harste G, Pring-Akerblom P. Rapid and quantitative detection of human adenovirus DNA by real-time PCR. J Med Virol 2003 June;70(2):228-39.

(131) Baylis SA, Shah N, Minor PD. Evaluation of different assays for the detection of parvovirus B19 DNA in human plasma. J Virol Methods 2004 October;121(1):7-16.

(132) Rotbart HA. Enzymatic RNA amplification of the enteroviruses. J Clin Microbiol 1990 March;28(3):438-42.

(133) Mohamed N, Elfaitouri A, Fohlman J, Friman G, Blomberg J. A sensitive and quantitative single-tube real-time reverse transcriptase-PCR for detection of enteroviral RNA. J Clin Virol 2004 June;30(2):150-6.

(134) Hansen J, Corydon TJ, Palmfeldt J et al. Decreased expression of the mitochondrial matrix proteases Lon and ClpP in cells from a patient with hereditary spastic paraplegia (SPG13). Neuroscience 2008 May 2;153(2):474-82. 


\section{Appendices}

\subsection{Appendix A}

\section{Staining procedure for CD3 and CD68}

Tissue samples obtained at autopsy were fixated by incubation in $4 \% \mathrm{w} / \mathrm{v}$ buffered $(\mathrm{pH} 7.4)$ formaldehyde for 2 days and then subjected to an automated tissue preparation (Leica ASP300S) with dehydration in 70 to $99 \%$ ethanol followed by clearing (Estisol 220, Esti Chem) and paraffin embedding (Histowax, Histolab products). The formalin-fixated and paraffin-embedded (FFPE) tissue samples were stored at room temperature until analysis.

The sections were de-paraffinized in xylene and re-hydrated through graded alcohols. Peroxidase activity was neutralized using $0.5 \% \mathrm{v} / \mathrm{v}$ hydrogen peroxide for 15 minutes. The slides were washed in running tab water followed by tris-buffered saline (TBS) for 5 minutes. The sections were exposed to tris/EDTA buffer pH 9 at 97 degrees for 30 minutes, washed with TBS at 65 degrees for 1 minute and placed in autostainer at room temperature. The sections were washed with TBS before $(5$ minutes) and after ( $3 \times 3$ minutes) incubation with primary antibodies (CD3/CD68) for 30 minutes. The sections were incubated with biotinylated secondary antibody for 30 minutes followed by TBS washing for $2 \times 3$ minutes. The sections were incubated with $D A B$ (3,3'diaminobenzidine) for 10 minutes, removed from the autostainer and rinsed in water. Finally the sections were counterstained with hematoxylin, dehydrated and mounted.

\subsection{Appendix B}

\section{Extraction of DNA/RNA from FFPE tissue samples}

Four formalin-fixed-paraffin-embedded (FFPE) myocardial tissue samples were analyzed from each autopsy case. The tissue samples were collected from four different locations of the heart: the anterior left ventricle (A), the posterior left ventricle (B), the interventricular septum (C) and the

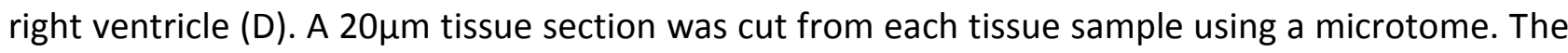
working area and the microtome knife were kept clean with RNaseZap ${ }^{\text {TM }}$ (Ambion), proline biocontrol (Biohit) and $99 \%$ ethanol. 
Two total nucleic acid extractions were performed from each case by mixing two $20 \mu \mathrm{m}$ tissue sections from different locations of the heart (location $A+B$ and location $C+D$ ) and using a customized total nucleic acid extraction protocol described previously ${ }^{116}$. Briefly, tissue sections were transferred to a $1.5 \mathrm{ml}$ microtube, overlaid with $300 \mu \mathrm{l}$ incubation buffer (part \#. D920D, Promega) and incubated for 10 minutes at $80{ }^{\circ} \mathrm{C}$. After cooling to $56{ }^{\circ} \mathrm{C}, 30 \mu \mathrm{l}$ of a $20 \mu \mathrm{g} / \mu \mathrm{l}$ proteinase $\mathrm{K}$ solution (Promega) was added and the sample was incubated for 3 hours at $56{ }^{\circ} \mathrm{C}$. The sample was mixed with $500 \mu \mathrm{l}$ RNA lysis buffer (part \#. Z3051, Promega) and transferred to a RNA purification cartridge containing a proprietary buffer system (cartridge part of AS1290 Maxwell ${ }^{\circledR} 16$ LEV Blood DNA Kit, Promega). The cartridge was processed in the automated Maxwell 16 instrument and the eluted total nucleic acid samples were stored at $-80{ }^{\circ} \mathrm{C}$ until PCR analyses were performed.

\section{Detection of viral genomes by PCR}

The total nucleic acid samples were analyzed in three separate PCR reactions, targeting an adenovirus-, parvovirus B19-, or enterovirus-specific viral genomic sequence. The three assays were designed as duplex real-time PCR assays targeting a virus-specific sequence and a human DNA or RNA region as an internal amplification control. All real-time PCR reactions were performed on the MX3005p (Agilent) real-time PCR instrument and fluorescence data (FAM and VIC) were collected from separate channels at the end of each extension step. A sample was considered positive when the amplification curve crossed a fluorescence threshold value of 0.1 (FAM) or 0.05 (VIC) before PCR cycle 40. A case was considered positive if the viral genome was detected by PCR in at least one of the two total nucleic acid extractions.

Detection of the human adenovirus DNA genome was based on a previously published real-time PCR assay that targets 51 human adenovirus prototypes ${ }^{130}$ using the forward primer 5'GCCACGGTGGGGTTTCTAAACTT-3', the reverse primer 5'TGCACCAGACCCGGGCTCAGGTACTCCGA-3' and a 5' hydrolysis probe containing a 6carboxyfluorescein (FAM) fluorescent reporter and a black hole quencher 1 (BHQ-1) dye (5'FAMTGCACCAGACCCGGGCTCAGGTACTCCGA-BHQ1-3')(MWG Eurofins). The PCR was performed with 2 $\mu \mathrm{l}$ of total nucleic acid template, $300 \mathrm{nM}$ of each primer and $250 \mathrm{nM}$ of the probe in a $25 \mu \mathrm{l}$ reaction using the TaqMan @ FAST Universal Master Mix (Life Technologies). Co-amplification of 
the human chromosomal gene RNase $\mathrm{P}$ with limited primer concentrations optimized for real-time multiplex PCR and detection by a VIC-labeled probe using a commercial assay (TaqMan@ RNase P Control, Life-technologies) served as the internal amplification control. The PCR amplification conditions were: $95{ }^{\circ} \mathrm{C}$ for $30 \mathrm{~s}$ followed by 45 cycles of $95{ }^{\circ} \mathrm{C}$ for $15 \mathrm{~s}, 55{ }^{\circ} \mathrm{C}$ for $15 \mathrm{~s}$ and $65{ }^{\circ} \mathrm{C}$ for 15 s.

Detection of the parvovirus B19 genomic DNA was based on a previously published real-time PCR assay that targets all three parvovirus B19 genotypes through amplification of a $193 \mathrm{bp}$ fragment of the NS1 gene ${ }^{131}$. Using the sequence alignment $i^{131}$ and the primer express software (Life technologies), we designed an assay that amplifies a shorter fragment of the parvovirus B19specific NS1 gene region, which is more suitable for analysis of fragmented DNA from FFPE tissue.

The forward primer 5'-TGAAACCCCGCGCTCTAGTA-3', reverse primer 5'AACTGGGCTTCCGACAAATG-3' and FAM dye-labeled hydrolysis probe $5^{\prime}$-FAMTCCCCGGGACCAGTTCAGGAGAA-NFQ-3’ (Taqman (C) MGB Probe, Life Technologies) were used in $25 \mu \mathrm{l} \mathrm{PCR}$ reactions containing $2 \mu \mathrm{l}$ of template, $300 \mathrm{nM}$ of each primer, $250 \mathrm{nM}$ of the probe and Taqman (C FAST Universal Master Mix (Life Technologies). Co-amplification of the human RNase P gene (TaqMan (C) RNase P Control, Life Technologies) served as the internal amplification control. The PCR amplification conditions were: $95^{\circ} \mathrm{C}$ for $2 \mathrm{~min}$ followed by 45 cycles of $95{ }^{\circ} \mathrm{C}$ for $15 \mathrm{~s}$ and $58^{\circ} \mathrm{C}$ for $30 \mathrm{~s}$.

Detection of the enterovirus genomic RNA was based on the amplification of a $5^{\prime}$ untranslated region that is highly conserved in enterovirus genomes ${ }^{132}$ with the forward primer $5^{\prime}$ GCCCCTGAATGCGGC-3', the reverse primer 5'-AATTGTCACCATAAGCAGC-3' and the $5^{\prime}$-FAMCGGAACCGACTACTTTGGGTGTCCGT-BHQ1-3' probe (MWG Eurofins), as previously described ${ }^{133}$. Co-amplification of a $121 \mathrm{bp}$ fragment of the human mitochondrial Lon protease mRNA with previously described primers and probe served as internal amplification control ${ }^{134}$. Amplification was performed with the GoTaq (C) Probe 1-step RT-qPCR kit (Promega) with $4 \mu$ l of template, 500 $\mathrm{nM}$ of each primer and $250 \mathrm{nM}$ of the probe in a $25 \mu \mathrm{l}$ reaction. The PCR conditions were: $42{ }^{\circ} \mathrm{C}$ for $20 \mathrm{~min}, 95^{\circ} \mathrm{C}$ for $10 \mathrm{~min}$ followed by 45 cycles of $95^{\circ} \mathrm{C}$ for $15 \mathrm{~s}$ and $59^{\circ} \mathrm{C}$ for $1 \mathrm{~min}$. 